\title{
Site U1394'
}

\author{
Expedition 340 Scientists $^{2}$
}

\section{Chapter contents}

Background and objectives. ......... 1

Operations................... 1

Lithostratigraphy................ 3

Paleontology and biostratigraphy ....... 7

Geochemistry ................ 8

Physical properties ..............9

Paleomagnetism ............... 10

Downhole logging .............. 11

References.................. 13

Figures.................. 15

Tables..................... 38

${ }^{1}$ Expedition 340 Scientists, 2013. Site U1394. In Le Friant, A., Ishizuka, O., Stroncik, N.A., and the Expedition 340 Scientists, Proc. IODP, 340: Tokyo (Integrated Ocean Drilling Program Management International, Inc.).

doi:10.2204/iodp.proc.340.104.2013

2Expedition 340 Scientists' addresses.

\section{Background and objectives}

Integrated Ocean Drilling Program (IODP) Site U1394 (proposed Site CARI-03C; $16^{\circ} 38.43^{\prime} \mathrm{N}, 62^{\circ} 2.29^{\prime} \mathrm{W} ; 1115$ meters below sea level [mbsl]) is located off the island of Montserrat $(\sim 13 \mathrm{nmi}$ [24 km] from Point Shoe Rock, at the southeast tip of Montserrat) (Fig. F1).

Site survey data obtained for Site U1394 revealed the presence of chaotic deposits interpreted as debris avalanche deposits (Deposit 2 and underlying Deposit 8) and indicated that drilling could penetrate through multiple units of debris avalanche Deposit 2 (Lebas et al., 2011; Watt et al., 2012). We planned to drill $244 \mathrm{~m}$ through volcanic and biogenic sediment with intercalated chaotic debris avalanche Deposit 2.

The objective for Site U1394 was to characterize processes that occur during debris avalanche emplacement and associated erosional processes. Study of the sediment overlying the masstransport deposit will allow us to date the associated event using $\delta^{18} \mathrm{O}$ chronostratigraphy. We will be able to determine whether the mass-wasting process occurred as a single event or as a series of closely spaced, separate events. Utilizing a combination of detailed lithologic, sedimentologic, and textural fabric analyses, we will be able to test the hypothesis that the debris avalanche incorporated sediment eroded from the seafloor during its emplacement. We hoped to reach the bedded units below the chaotic debris avalanche unit and thus investigate the textural and structural characteristics of the base of the debris avalanche (Komorowski et al., 1991; Glicken, 1991, 1996). Existing numerical models of debris avalanche emplacement do not sufficiently consider the interaction of the debris avalanche with the substratum and its influence on the mobility of the flow. Our goal was to look for structural evidence of the development of shear zones from the base of the debris avalanche into the overlying plug and fluidization structures (clastic dikes) described in terrestrial debris avalanche deposits (e.g., Glicken, 1996; Voight et al., 2002; Gee et al., 1999; Clavero et al., 2002; Shea et al., 2008).

\section{Operations}

\section{Transit to Site U1394}

After a $5.3 \mathrm{nmi}$ transit from Site U1393 in dynamic positioning (DP) mode, the vessel arrived at Site U1394. The vessel stabilized 
over Site U1394 at $1230 \mathrm{~h}$ on 8 March 2012. All times reported in this volume are given in ship local time, which was Universal Time Coordinated (UTC) - $4 \mathrm{~h}$. The position reference was a combination of GPS signals and a single acoustic beacon. The positioning beacon was deployed at $1750 \mathrm{~h}$ on 8 March. It was recovered at $2315 \mathrm{~h}$ on 12 March at the conclusion of operations at Site U1394.

\section{Site U1394}

Two holes were cored at Site U1394 (Table T1). The original plan called for two holes drilled to 244 meters below seafloor (mbsf). Because drilling conditions were challenging, coring took longer than anticipated, and because the section below 180 mbsf was deemed to be less scientifically interesting, the second hole was shortened to 180 mbsf. Hole U1394B was successfully logged with both the Formation MicroScanner (FMS)-sonic and triple combination (triple combo) logging strings, but an attempt to perform a vertical seismic profile (VSP) experiment was canceled when all efforts to deploy the Versatile Seismic Imager (VSI) tool string through the bottom-hole assembly (BHA) failed. After trying unsuccessfully to lower the tools into the formation, 48 cores were recovered at this site. The extended core barrel (XCB) was deployed 28 times, and the advanced piston corer (APC) was deployed 20 times. The interval cored with the XCB was $265.8 \mathrm{~m}$ with a recovery of only $36.93 \mathrm{~m}$ of core $(14 \%)$. The interval cored with the APC was $160.10 \mathrm{~m}$ with a recovery of $161.59 \mathrm{~m}$ of core (101\%). Overall recovery for Site U1394 was 47\%.

\section{Hole U1394A}

The vessel arrived at Site U1394 and was in position at $1230 \mathrm{~h}$ on 8 March 2012. After an uneventful pipe trip, the vibration-isolated television (VIT) frame was installed and run to bottom for a required camera survey. Because a subsea communications cable had been run in the general area of operations, a camera survey was performed and recorded to make certain that our operations would not impact the cable. At $1630 \mathrm{~h}$ the bottom survey began at the preliminary site coordinates. A $40 \mathrm{~m} \times 40 \mathrm{~m}$ survey was conducted without signs of a subsea cable. The seafloor was tagged twice during the survey to establish the depth from the drill floor to the seafloor. Tagged depth at both locations was 1126.6 meters below rig floor (mbrf). After the survey was completed, the VIT frame was removed, the top drive was picked up, and the bit was spaced out to spud Hole U1394A. The hole was spudded at $1945 \mathrm{~h}$ on 8 March. The seafloor depth was calculated from the length of the first core: $1126.3 \mathrm{mbrf}(1114.9 \mathrm{mbsl})$. APC refusal in Hole U1394A came on the fourth piston core at
23.9 mbsf. The XCB was then deployed, and coring continued through Core 340-U1394A-27X without problems but with generally poor recovery. Four piston cores were taken over a $23.9 \mathrm{~m}$ interval with a total recovery of $24.17 \mathrm{~m}$. Twenty-three XCB cores were cut over a $220.6 \mathrm{~m}$ interval with a recovery of $33.20 \mathrm{~m}$. Overall core recovery for Hole U1394A was $57.37 \mathrm{~m}$ for the $244.50 \mathrm{~m}$ interval (24\%).

Just after midnight on 10 March, while retrieving Core 28X, the wireline overshot detached from the XCB barrel. The winch operator noted the immediate weight loss on the wireline weight indicator and informed the driller of the situation. The sinker bar assembly was pulled to the surface, the drill string connection was opened, and the wireline sinker bar assembly was inspected to determine where the overshot assembly parted. Upon investigation, we determined that the male thread on the overshot core unscrewed from the lower crossover on the sinker bar assembly. This connection is coated with Bakerlok and utilizes a split pin penetrating through the crossover adaptor sub female, preventing the upper mandrel on the overshot core from backing off.

A male two-lug quick release attached to a rotary core barrel (RCB) core catcher sub loaded with standard RCB hard formation catchers was deployed on the wireline in an attempt to catch the upper threaded mandrel on the overshot core assembly. The first deployment was unable to catch the overshot core mandrel, so a second attempt was made. When the mud pumps were engaged after tightening the pipe connection, the drill string was packed off and then bled off. Shortly thereafter drill string rotation was lost, and the Toolpusher and Driller phoned the Offshore Installation Manager (OIM) to assist with freeing the stuck pipe. Attempts were made to regain rotation and circulation for $\sim 3.5 \mathrm{~h}$, and the decision was made to call out the Schlumberger Wireline Engineer to begin preparations to sever the drill string just below the upper connection on the tapered drill collar (TDC).

While the Schlumberger Wireline Engineer made the necessary checks of the severing tool case and casingcollar locator (CCL) tool, a Bowen wireline fishing overshot was deployed twice in an attempt to grab the overshot outer body. These attempts failed, and the fishing overshot was laid out. The severing tool string less the detonator and explosive housing was laid out on the rig floor in preparation for severing operations. The $30 \mathrm{ft}$ drill knobby was laid out from the drill string to lower the block height for installing the severing tool string. Items that required de-energizing in preparation for severing operations included the ship's radars, radio room radio frequency transmitters, and Wi-Fi circuits. 
After securing all of the high-energy radio frequency sources, the explosive charge was assembled in the Core Tech shop, brought to the drill floor, and installed on the Schlumberger electric logging line. The explosive charge assembly and CCL tool were installed into the top of the drill string and down through the traveling blocks and TDS-3. After deploying the severing assembly $\sim 100 \mathrm{~m}$ below the drill floor inside the pipe, ground tabs were clamped to the drill string and piperacker stabber assembly and ground straps were attached in preparation for severing the pipe.

The severing tool string was lowered via the electric logging line to the top of the BHA, the severing point was located and verified with the CCL, and the drill sting was severed at $1420 \mathrm{~h}$ on 10 March at $\sim 1240$ mbrf, just below the upper connection of the TDC. All BHA components below the $5 \frac{1}{2}$ inch transition pipe were left in the hole along with the XCB core barrel and Core 28X.

Schlumberger severing equipment was rigged down, and the wireline was pulled back to the surface. The drill string was then pulled back with the top drive still installed to $1201 \mathrm{mbrf}$, and the $20 \mathrm{ft}$ knobby and top drive were set back. The remainder of the drill string was tripped to the surface, and the severed end of the TDC cleared the rotary table at $1845 \mathrm{~h}$ on 10 March, officially ending Hole U1394A.

The flared end of the tapered collar was torched off, and the remains of the TDC were removed from the $5 \frac{1}{2}$ inch transition drill pipe.

\section{Hole U1394B}

A new bit and BHA were picked up, drifted, measured, and run into the hole for Hole U1394B. The trip to bottom was uneventful. The vessel was offset $20 \mathrm{~m}$ north from Hole U1394A and spudded at $0255 \mathrm{~h}$ on 11 March 2012. Seafloor depth was calculated from the mudline recovery: $1125.6 \mathrm{mbrf}$ (1114.2 mbsl). For Core 340-U1394B-2H, the APC recovered only $6.4 \mathrm{~m}$ of core, and the $\mathrm{XCB}$ was deployed for the next five cores. After Core 7X, the APC was again picked up and used to complete the hole to $181.4 \mathrm{mbsf}$ with Core $21 \mathrm{H}$. The entire section was difficult to piston core with frequent partial strokes, and overpull was noted on all cores but one after Core $8 \mathrm{H}$. Seven of the cores had to be drilled over to release them from the formation. Sixteen piston cores were taken over a $136.2 \mathrm{~m}$ interval with a total recovery of $137.42 \mathrm{~m}$ of core. Five XCB cores were cut over a $45.2 \mathrm{~m}$ interval with a recovery of $3.73 \mathrm{~m}$ of core. Overall core recovery for Hole U1394B was $141.15 \mathrm{~m}$ for the $181.4 \mathrm{~m}$ interval (78\%). At the conclusion of coring, Hole U1394B was conditioned with a $30 \mathrm{bbl}$ high-viscosity mud sweep and displaced with $71 \mathrm{bbl}$ of $10.5 \mathrm{ppg}$ mud for logging. The drill string was then pulled back, the top drive was set back, the bit was set at 82.69 mbsf, and the pipe was hung from the blocks. Schlumberger was then rigged up for logging, and the triple combo was deployed without the nuclear source. Two successful passes were made to $179.4 \mathrm{mbsf}$, and the triple combo string was rigged down. After a meeting with the logging staff and science party management, the VSI tool was rigged up and run down the drill string. Simultaneously the protective species watch began. After observing all seismic operating procedures, the seismic guns were ramped up in preparation for the VSP experiment. Unfortunately, the VSI tools were unable to pass through the BHA, and after $3 \mathrm{~h}$ of trying various means of getting the tools to pass the BHA, the VSI tool string was brought back to the surface and the VSP experiment was cancelled. The VSI tool string was rigged down, and the FMS-sonic tool string was picked up. A small delay was incurred when the tool string failed to test before deployment. After successfully troubleshooting the electrical issue, the tool was run to $180.4 \mathrm{mbsf}$ and two passes were made over the length of the open hole. The tools were then pulled back to the surface and rigged down. The knobbies were laid out, and the drill string was pulled from the hole. The bit cleared the rotary table at $0140 \mathrm{~h}$, and the drill floor was secured at $0145 \mathrm{~h}$, ending Site U1394 and Hole U1394B. The vessel then proceeded underway to Site U1395.

\section{Lithostratigraphy}

The primary lithologies at Site U1394 are described here, followed by associations of lithologies that form a series of lithostratigraphic units (A-F).

\section{Hemipelagic mud}

Site U1394 background sediment mainly consists of fine-grained calcareous biogenic fragments and siliciclastic sediment (Fig. F2A). The background sediment is often pale yellowish gray to dark gray in color and varies from fine silt to fine mud in grain size. The variety in colors could be caused by the compositional ratios between biogenic grains, volcaniclastic grains, and grains of other origins. The sediment mainly consists of a moderately to poorly sorted homogeneous carbonate-rich matrix, but it has diffusely laminated intervals or mottled coloration in places. It occasionally contains millimeter-scale dark greenish layers (possibly altered clay minerals) that can be sharp or diffuse, tiny black organic matter, small shell fragments, and heterogeneous sandy patches (possibly in-filled burrows). In case of interbedded sandy 
turbidities or ash layers, layer boundaries are distinct and sometimes erosive at the base of turbidites.

\section{Turbidite sand and mud}

Turbidites are characterized by normal grading and massive well-sorted mud (for thin deposits a few centimeters thick) to very coarse sand with maximum grain size (for thick deposits measured in meters) (Fig. F2B). Turbidite deposits generally consist of a mixture of volcaniclasts and bioclasts. Volcaniclasts include fragments of fresh andesitic lava and pumice, altered lava, and crystals (feldspar, amphibole, and so on). Bioclasts include fragments of carbonate materials such as corals and shells. Occasionally, a few $(<10)$ percent of granule- to pebble-sized clasts $(<5 \mathrm{~cm})$ or mud clasts are included. The ratio of volcaniclastic to bioclastic components varies. In some turbidite units bioclasts occupy $>50$ vol\%. Thin turbidites (a few centimeters thick) are generally interlayered in Units A and E, and thick turbidites (as thick as several meters) occur in the upper part of Unit B and most of Unit D.

\section{Mafic volcaniclastic/tephra deposits}

Well-sorted dark color layers that represent fallout from a series of eruptions of basaltic magmas from the South Soufrière Hills volcanic center (131-138 ka; Le Friant et al., 2008) are seen in Subunit A-7 in Holes U1394A and U1394B. Basaltic eruptions are absent during activity of the Soufrière Hills volcanic center (250 ka to recent); thus, basaltic fallout layers are good regional markers in cores around Montserrat.

\section{Other tephra fall deposits}

Other types of volcanic ash layers, probably of fallout origin, occur elsewhere in the cores. The interpretation of ash layers is based on visual core observations (such as color, a well-sorted nature, grading, and so on) and petrographic features seen in smear slide analysis. At the base of the cores from Hole U1394B, several dark tephra layers composed partly of scoria are observed. It is probable that some of these tephra layers originate from volcanoes on Guadeloupe, as several basaltic eruptions are already recognized there.

\section{Lithostratigraphic units}

Lithostratigraphic unit boundaries at Site U1394 are defined by abrupt or gradational changes in the abundance of lithologies and by distinctive marker horizons such as basaltic fall and turbidity current deposits. Uncertainties concerning the depths of these unit boundaries are sometimes significant.

\section{Unit A}

Depths: Hole U1394A = 0-6.5 mbsf, Hole U1394B = 0-8 mbsf

Unit A extends from the seafloor to a series of distinctive basaltic fall and flow deposits from $6.5 \mathrm{mbsf}$ (Hole U1394A) to 8 mbsf (Hole U1394B). Unit A is divided into a series of seven subunits (A-1 to A-7).

\section{Subunit A-1}

The youngest stratigraphic subunit, A-1, extends $21 \mathrm{~cm}$ (0-0.21 mbsf; Hole U1394A) or $48 \mathrm{~cm}$ (0-0.48 mbsf; Hole U1394B) below the seafloor and comprises two (Hole U1394A) or three (Hole U1394B) volcaniclastic turbidites (Fig. F2). Each turbidite fines upward from a sandy base into a muddy top and comprises mainly andesitic lava grains with very little bioclastic material. This subunit is poorly consolidated and often appears deformed, most probably as a result of the coring process. APC coring typically fails to recover the uppermost few centimeters of "soupy" sediment immediately below the seafloor, so this subunit may actually be as much as a few tens of centimeters thicker. The lower boundary of Subunit A-1 is a sharp contact with underlying hemipelagic sandy mud.

\section{Subunit A-2}

Subunit A-2 comprises the $20 \mathrm{~cm}$ of hemipelagic mud below Subunit A-1 and an underlying volcaniclastic turbidite, which is $2-6 \mathrm{~cm}$ thick and consists of fine sand.

\section{Subunit A-3}

Subunit A-3 comprises $33-41 \mathrm{~cm}$ of hemipelagic mud immediately below Subunit A-2 and an underlying, more bioclastic rich turbidite, which also has a significant volcaniclastic component. The turbidite comprises $2-3 \mathrm{~cm}$ of fine sand and probably as much as $4 \mathrm{~cm}$ of overlying turbidite mud.

\section{Subunit $A-4$}

Subunit A-4 comprises $20 \mathrm{~cm}$ of hemipelagic mud below Subunit A-3 and a thicker series of stacked multiple turbidites. The turbidites grade from sand to mud, although in many cases there is erosive sand-on-sand contact. The turbidites have a variety of more bioclastic and more volcaniclastic compositions, shown by lighter or darker gray hues. Indeed, a single turbidite can grade from more bioclastic rich to more volcaniclastic rich. Hole U1394A contains $\sim 9$ turbidites where Subunit A-4 is $140 \mathrm{~cm}$ thick, and Hole U1394B contains at least 10 or 11 turbidites where Subunit A-4 is $\sim 200 \mathrm{~cm}$ thick. A series of three finer grained and thinner turbidites occurs within the subunit in both holes. 


\section{Subunit A-5}

The upper part of Subunit A-5 comprises $23 \mathrm{~cm}$ (Hole $\mathrm{U} 1394 \mathrm{~B})$ to $50 \mathrm{~cm}$ (Hole U1394A) of hemipelagic silty mud, underlain by two stacked volcaniclastic turbidites that total $14 \mathrm{~cm}$ (Hole U1394A) or $19 \mathrm{~cm}$ (Hole U1394B).

\section{Subunit A-6}

Subunit A-6 comprises $50 \mathrm{~cm}$ (Hole U1394A) or $55 \mathrm{~cm}$ (Hole U1394B) of hemipelagic mud beneath Subunit A-5; this hemipelagic mud is underlain by six stacked turbidites that are $55 \mathrm{~cm}$ (Hole U1394A) or $45 \mathrm{~cm}$ (Hole U1394B) thick. The turbidites are normally graded from sand to mud. In both holes the uppermost five turbidites are volcaniclastic and the basal turbidite is more bioclastic.

\section{Subunit A-7}

Subunit A-7 is better exposed in Hole U1394A, where it was not sampled in the core catcher (Fig. F2). Three distinctive basaltic fallout layers are recognized in intervals 340-U1394A-2H-2, 19-25 cm (Layer BFa); $2 \mathrm{H}-2,25-38 \mathrm{~cm}$ (Layer BF-b); and 2H-2, 58-83 cm (Layer BF-c). The depths at the top of the uppermost fallout layer (BF-a) are 6.5 mbsf (Hole U1394A) and 7.8 mbsf (Hole U1394B). Two basaltic turbidites are interlayered with the fallout units. The first turbidite overlies basaltic fallout Layer BF-a, from 0 to $19 \mathrm{~cm}$, and the other basaltic turbidite separates Layers BF-b and BF-c between 38 and $58 \mathrm{~cm}$. The three basaltic fallout layers are normally graded, fining upward from pebble to fine sand. The thicknesses of Layers $\mathrm{BF}-\mathrm{a}, \mathrm{BF}-\mathrm{b}$, and BF-c are 6,13 , and $25 \mathrm{~cm}$, respectively.

Two of the same basaltic fallout layers (BF-a and BFb) are recognized in intervals 340-U1394B-1H-6, $40.5-44.5 \mathrm{~cm}$; and $1 \mathrm{H}-6,44.5-60 \mathrm{~cm}$, respectively. The thicknesses of the basaltic fallout layers in Hole U1394B are $4 \mathrm{~cm}$ (Layer BF-a) and $15.5 \mathrm{~cm}$ (Layer BFb), similar to the thicknesses of those layers in Hole U1394A. Grain sizes are finer in the basaltic fallout deposits of Hole U1394B, both of which fine upward from granule to mud.

\section{Unit B}

Depths: Hole U1394A = 6.5-50 mbsf, Hole U1394B = 8-50 mbsf

Unit B extends from 6.5 or 8 mbsf to $\sim 50$ mbsf (see Section 340-U1394B-7X-1).

\section{Subunit B-1}

Subunit B-1 immediately underlies the basaltic horizons of Subunit A-7, and its upper part comprises a relatively thick interval of stacked and amalgamated turbidites that are often relatively coarse grained.
The variable composition of the turbidites, more bioclastic or more volcaniclastic rich, produces complex changes in their gray hues. Individual fining-upward turbidites show compositional (gray hue) zoning. The turbidites are always massive (Ta division of Bouma, 1962), such that planar or ripple cross-lamination is always absent, suggesting rapid deposition that prevented bed-load reworking into laminae. The turbidites contain andesitic clasts, bioclasts (including coral), and mud clasts, which can be several centimeters in length. The subunit is at least $18 \mathrm{~m}$ thick.

A $1 \mathrm{~m}$ thick interval of very contorted hemipelagic silty mud with fine laminae lies within Section 340U1394A-2H-6. This interval is most likely a mud clast but could represent a deformed hemipelagic interbed. A second interval of hemipelagic mud and flat-lying thin turbidites in Section 340-U1394A-3H-1 is deformed, but only weakly. This second interval could either be in situ or a second clast. Hemipelagic intervals are also found in Core 340-U1394B-3X.

\section{Subunit B-2}

The lower part of Unit B was not recovered in Holes U1394A and U1394B, suggesting that it is even more difficult to recover with either piston or rotary coring and therefore may potentially be coarser grained. The core catcher samples comprise a few centimeters of mixed volcaniclastic-bioclastic sand and andesitic pebbles as large as $4 \mathrm{~cm}$.

\section{Unit C}

Depths: Hole U1394A = 50-74 mbsf, Hole U1394B = 50-74 mbsf

Unit C extends from 50 to $74 \mathrm{mbsf}$, but its boundaries are poorly constrained. Unit $C$ contains a greater abundance of hemipelagic sediment than Units B and D. Individual continuous intervals of hemipelagic silty clay are up to $130 \mathrm{~cm}$ thick. This unit also contains volcaniclastic turbidites that are up to $40 \mathrm{~cm}$ thick.

\section{Unit D}

Depths: Hole U1394A = 74-91.5 mbsf, Hole U1394B = 74-110 mbsf

Unit D extends from $\sim 74$ mbsf to either 91.5 or 110 mbsf. This unit was only recovered well in Hole U1394B, where it is dominated by massive coarsegrained turbidite sandstones that comprise variable amounts of volcaniclastic and bioclastic material. This variability causes changes in gray hue. Individual graded turbidite units are often $>1 \mathrm{~m}$ thick, and there are numerous graded units. Planar lamination or cross-lamination (divisions $\mathrm{Tb}$, c, and d of Bouma, 1962) are always absent. The chaotically distributed 
clasts in some ungraded sections may suggest en masse emplacement by debris flow, and clasts of sand and mud (as well as andesitic lava and bioclasts) can be several centimeters in length. Adjacent massive but graded sand intervals are most likely deposited in a layer-by-layer fashion from the base of high-density turbidity currents. There are no fine mud interbeds in this unit, and its duration of emplacement is uncertain. It could represent multiple events or multiple pulses in one event.

\section{Unit E}

Depths: Hole U1394A $=91.5-181$ mbsf, Hole $\mathrm{U} 1394 \mathrm{~B}=110-181.4$ mbsf (bottom of hole)

Unit E extends from either 91.5 or 110 mbsf to at least $181 \mathrm{mbsf}$. This unit comprises interbedded mud hemipelagite and turbidite intervals and was much better recovered in Hole U1394B. The position of its upper boundary is uncertain and is placed at the first interval of hemipelagic mud. If an interval in Sections $340-\mathrm{U} 1394 \mathrm{~B}-12 \mathrm{H}-1$ and $12 \mathrm{H}-2$ is indeed hemipelagic mud, then the top of Unit $\mathrm{E}$ is at $91.5 \mathrm{mbsf}$. However, if this interval is turbidite silt and mud, then the top of Unit E is at 110 mbsf. The interval between 91.2 and 110 mbsf is coarse-grained material, sometimes with chaotic clasts suggestive of en masse emplacement by debris flow and sometimes with massive sand that may have flowed during coring. The first unequivocal interval of hemipelagite mud is at 110 mbsf in Section 340-U1394B-14H-1.

Unit E contains significant amounts of hemipelagic mud. The upper part of Unit E contains relatively thick and coarse-grained turbidites, and turbidite abundance and thickness is lower in the middle part of Unit E. Turbidite thickness could increase again near the base of the unit. The turbidite sands can be volcaniclastic, bioclastic, or mixed in character, and they range in thickness from a few centimeters to a few meters.

At several levels (e.g., Sections 340-U1394B-16H-1 and 16H-2; Section 340-U1394A-20X-1), there are massive silty brown tephra layers composed of ash, some of which are $20 \mathrm{~cm}$ thick. These brown silt layers tend to occur in clusters.

The lower-middle part of the interval is heavily bioturbated by distinctive large burrows (e.g., Core 340-U1394A-17X).

A prominent $8 \mathrm{~m}$ thick and coarse unit (154162 mbsf; Core 340-U1394B-19H) contains $\sim 5 \%$ pumice clasts, which are even more abundant near the top of the unit. The pumice clasts are $\leq 5 \mathrm{~cm}$ in diameter. The finer matrix comprises crystals. The unit does not contain obvious breaks in sedimentation and could be a single event bed. A $>5 \mathrm{~m}$ thick volcaniclastic turbidite occurs at the base of Unit E in Hole U1394B.

\section{Unit F}

Depth: Hole U1394A = 181-235 mbsf (bottom of hole)

Unit $\mathrm{F}$ extends deeper than 181 mbsf and certainly deeper than 215 mbsf, but the base of the unit was not reached. In Hole U1394A this unit was poorly recovered, suggesting that it was relatively coarse grained. Andesitic clasts were recovered in core catcher samples below 215 mbsf. Hole U1394B terminated within Unit $\mathrm{E}$ and did not reach Unit F.

\section{Igneous petrology and alteration}

Hard rock petrology at Site U1394 reflects the dominant magmatic products of Montserrat. Thin sections were prepared of a gray, poorly vesicular andesite clast (Sample 340-U1394A-6X-CC, 9-13 cm), a whitegray andesite pumice clast (Sample 22X-1, 27-28 cm), and grain mounts of four volcaniclastic tephra layers (Samples 2H-2, 65-66 cm; 24X-1, 89-90 cm; 24X-2, $16-18 \mathrm{~cm}$; and $24 \mathrm{X}-2,42-43 \mathrm{~cm}$ ).

The andesite lava and pumice fragment contained similar phase assemblages but differed in texture. The lava clast is porphyritic with an approximately 60:40 mix of groundmass and phenocrysts. The phenocryst assemblage consists of plagioclase (70\%), amphibole (25\%), Fe-Ti oxides (4\%), and orthopyroxene $(1 \%)$. The plagioclase phenocrysts are euhedral, lath-shaped grains as long as $3.5 \mathrm{~mm}$, commonly exhibiting albitic twinning. Many of the grains contain sieved cores, evidence of previous resorption, although all cores are surrounded by clean overgrowth. Two populations of amphibole phenocrysts are observed: the larger crystals ( $\leq 4.6 \mathrm{~mm}$ long) are fully reacted to a fine-grained mix of oxides and pyroxenes (decompression reaction rims; Devine et al., 1998); the smaller crystals $(\leq 0.25 \mathrm{~mm}$ long $)$ are thin rimmed. Both populations are euhedral to subhedral and elongate. No significant oxidation of the smaller clasts is observed. Orthopyroxene and Fe-Ti oxides occur as euhedral tabular and subhedral microphenocrysts, respectively. The phenocrysts are contained in a microcrystalline matrix of plagioclase, oxide, and pyroxene microlites. No flow lineation was observed in the lava clast.

The pumice clast contained a similar phase assemblage with a distinctly different groundmass. Vesicle population made up $\geq 50 \%$ of the clast. The remaining clast was a 70:30 mix of groundmass and crystals. The groundmass was composed of glassy materials exhibiting flow lineation. The phenocryst proportions were similar to the andesite lava clast. 
The grain mount of the uppermost volcaniclastic tephra layer (Sample 340-U1394A-2H-2, 65-66 cm) appears to be basaltic in composition. It contains fragments of plagioclase, olivine, clinopyroxene, and oxides in descending abundance. Some of the microcrystalline matrix is still present on the rims of some of the grains. This layer forms part of the A-7 marker subunit.

Grain mounts lower in the core (Samples 340U1394A-24X-1, 89-90 cm; 24X-2, 16-18 cm; and $24 \mathrm{X}-2,42-43 \mathrm{~cm}$ ) appear to be of basaltic andesite or andesite composition. These grain mounts correspond to three distinct volcaniclastic sand units. The mineralogy of the mounts consists of fragments of plagioclase, amphibole, orthopyroxene, and Fe-Ti oxides. Small fragments of biogenic material and microcrystalline magmatic matrix are present as well. The average grain size within the grain mount is $<0.2 \mathrm{~mm}$. The mineral assemblage does not appear to vary significantly between units. No textural interpretation of the grain mounts is possible.

\section{Paleontology and biostratigraphy}

Core catcher samples from Site U1394 contain calcareous nannofossils and planktonic and benthic foraminifers of varying abundances and at varying levels of preservation. Many core catcher samples are characterized by large volcanic clasts, coral fragments, and abundant reef-dwelling benthic foraminifers. The high fragmentation and relatively poor preservation of the foraminifers suggests the presence of much reworked material. Pteropods and heteropods were found in many samples and are often well preserved though highly fragmented. Ostracods are also present in low numbers (1-5 per sample). Biostratigraphic data derived from both calcareous nannofossils and planktonic foraminifers show that Site U1394 contains many levels of reworked sediment from the early Pleistocene amid a background of late Pleistocene sedimentation (Fig. F3).

\section{Calcareous nannofossils}

Only 18 of the 26 core catcher samples from Hole U1394A were prepared for nannofossil analysis. The remaining samples were not analyzed because of the coarse nature of the material. Sediment analyzed in Hole U1394A contains specimens of several species, including Gephyrocapsa caribbeanica, Pseudoemiliania lacunosa, Calcidiscus leptoporus, and Helicosphaera kamptneri. Recent species such as Rhabdospaera clavigera and Calciosolenia murrayi are found in many samples throughout the entire sequence. Emiliania huxleyi was not found in core catcher samples from Hole U1394A, possibly because of small sample size and poor preservation.

Two datum species and two older reworked species were found in core catcher samples from Hole U1394A. Helicosphaera inversa, a very important species because of its short range, is present within most of the hole, dating Hole U1394A to within the Pleistocene. P. lacunosa, a species indicative of early Pleistocene sediment, is also abundant in nearly all samples, with particularly large specimens $(>7 \mu \mathrm{m})$ in Sample 340-U1394A-24X-CC. Helicosphaera sellii (Zones CN10-CN13) was identified in Samples 340U1394A-1H-CC, 9X-CC, and 10X-CC, suggesting the presence of older reworked material. Some early Pliocene (Zone CN11) discoasterids were also found in Sample 340-U1394A-20X-CC; however, specimens were poorly preserved and detailed identification was not possible. Nannofossil evidence assigns Hole U1394A to Zone CN14 (Okada and Bukry, 1980) or the P. lacunosa Zone (Gartner, 1977). Hole U1394B contains a higher number of reworked species from the early Pliocene but is otherwise consistent with Hole U1394A. H. sellii (reworked) and H. inversa were also found in Hole U1394B, $H$. inversa placing the sediment within Zone CN14 (Okada and Bukry, 1980 ) or the P. lacunosa Zone (Gartner, 1977).

\section{Planktonic foraminifers}

Of the 26 core catcher samples collected in Hole U1394A, 20 were analyzed for planktonic foraminiferal content, along with all 21 of the samples collected in Hole U1394B. The remaining core catcher samples are unsuitable for analysis because of the coarse grain size of the sediment retrieved. Planktonic foraminifers are present in all samples, although some were found at very low abundances (few-present), possibly due to the high volume of volcanic material (Samples 340-U1394A-3H-CC and 4H-CC; 340-U1394B-20H-CC and 21H-CC). Samples 340-U1394A-26X-CC and 340-U1394B-13H-CC contain the lowest abundances (present), with only one specimen of planktonic foraminifer in each. In most samples, the assemblage of planktonic foraminifers is diverse but dominated by Globigerinoides ruber (white) and Globigerinoides sacculifer. Other abundant species include Globigerina falconensis, Globigerinita glutinata, Globigerinoides elongatus, Globorotalia tumida, and Neogloboquadrina dutertrei (dextral). The fauna does not change significantly throughout Site U1394, with two exceptions. Samples 340-U1394A7X-CC and 9X-CC contain abundant specimens of the subtropical species Globigerina rubescens, which was only found in low abundances (few) in Hole U1394B (Samples 340-U1394B-3X-CC and 5X-CC) 
and was not found in any other samples. Additionally, Sample 340-U1394B-11H-CC appears to consist solely of juvenile planktonic foraminifers. Species present in all samples are indicative of warm subtropical waters. Three datum species were commonly encountered: Globorotalia flexuosa (0.07-0.40 Ma), Globigerinella calida (bottom occurrence [B] at $0.22 \mathrm{Ma}$ ), and Globorotalia tosaensis (top occurrence $[\mathrm{T}]$ at $0.61 \mathrm{Ma})$, dating the site to within the Pleistocene. Several of the samples (340-U1394A-2H-CC, 10X-CC, and 20X-CC; Cores 340-U1394B-14H, 15H, $17 \mathrm{H}$, and $18 \mathrm{H}$ ) contain species that indicates sediment from the late Pleistocene (presence of G. calida, B $0.22 \mathrm{Ma}$ ) as well as the early Pleistocene (presence of $G$. tosaensis, T $0.61 \mathrm{Ma}$ ), suggesting reworking of sediment. A more detailed postcruise investigation of samples throughout the core will be beneficial in understanding these variations.

\section{Benthic foraminifers}

A total of 53 genera and 53 species were identified at Site U1394. Samples examined for benthic foraminifers in Holes U1394A and U1394B varied in abundance, diversity, and preservation. Rotaliids have the highest diversity but are present in low abundances (1-5 specimens per sample) overall in Holes U1394A and U1394B. Several samples (340-U1394A-2H-CC, 7H-CC, 10H-CC, and 14X-CC; 340-U1394B-4H-CC, 9X-CC, and 10X-CC) are dominated by poor to moderately preserved Amphistegina sp. This genus is common of reef environments ( $\leq 100 \mathrm{mbsf})$, and its presence is indicative of reworking associated with volcaniclastic sediment. Cibicides sp. and Cibicidoides sp. are present in low abundances in most samples, with Cibicides wuellerstorfi being the most abundant species. Agglutinated foraminifers are very rare, with only one specimen of Reophax sp. and Ammobaculite sp. found in two samples. Based on the presence of the genera Osangularia, Globocassidulina, and Cibicides, as well as Laticarinina pauperata, a bathyal paleodepth is inferred for Holes U1394A and U1394B.

\section{Geochemistry}

Samples for headspace analyses were taken from 12 depths in Hole U1394A; none were taken from cores that consisted largely of coarse-grained material. One sample (from Section 340-U1394A-9X-1) had a methane concentration of $4.7 \mathrm{ppm}$, but all other samples had levels between 1.9 and $3.3 \mathrm{ppm}$. No higher hydrocarbons were detected.

Twenty-nine samples were taken for X-ray diffraction (XRD) and carbonate analysis. XRD results fall into three groups. Samples from pelagic sediment intervals predominantly contain calcite and high-Mg calcite \pm aragonite, together with minor volcanic phases (mostly plagioclase with lesser orthopyroxene and hornblende) and clay minerals that cannot be readily identified on the XRD pattern (Fig. F4A). Samples from volcanic-rich horizons contain dominant plagioclase and lesser amounts of orthopyroxene and hornblende, along with minor sedimentary carbonate (Fig. F4B). One tephra layer contains abundant smectite in addition to the volcanic minerals and background pelagic phases noted above (Fig. F4C; Table T2).

$\mathrm{CaCO}_{3}$ weight percent is much higher in the largely pelagic sections than in the largely volcanic turbidites, but the presence of $3.5-7.5 \mathrm{wt} \% \mathrm{CaCO}_{3}$ in some of the latter indicates a significant biogenic component (Fig. F5A). Organic carbon concentrations in the pelagic sections are similar to those expected in this area (up to or exceeding $\sim 1 \mathrm{wt} \%$ ) and lower in the turbidite sections $(<0.2 \mathrm{wt} \%)$ (Fig. F5B; Table T2).

It is not possible to collect meaningful pore water data from permeable turbidite and turbidite horizons, so pore fluid samples were largely taken from intervals dominated by pelagic carbonate. Alkalinity values increased from $3.3 \mathrm{mM}$ in the uppermost section (340-U1394A-1H-3; $4.4 \mathrm{mbsf}$ ) to a consistent value of $11.5 \mathrm{mM}$ at $132.8 \mathrm{mbsf}$ before decreasing to $7.5 \mathrm{mM}$ at the base of the hole (Fig. F6A). pH values remain relatively constant at 7.4-7.5 throughout the hole. Ammonia concentrations increase from $\sim 0.1 \mathrm{mM}$ in the uppermost sample to $\sim 2.1 \mathrm{mM}$ at 127.6 mbsf before decreasing to $\sim 1.7 \mathrm{mM}$ in the deepest sample at 175.6 mbsf (Fig. F6B). Of the major cations, calcium decreases from values close to bottom water in the uppermost sample to reach a minimum at 120 mbsf before increasing toward the bottommost sample (Fig. F6C), whereas magnesium shows a monotonic decrease in concentration with depth (Fig. F6D). Sodium and potassium concentrations exhibit a weak increase $(\mathrm{Na})$ and decrease $(\mathrm{K})$ with depth (Table T3). $\Sigma$ S concentrations show a pattern similar to that of calcium (Fig. F6E). Chloride concentrations fluctuate within the normal range (540-580 mM) expected for pore water obtained from squeezing carbonate sediment. Overall, pore water data are consistent with diagenesis of carbonate-rich sediment with organic carbon concentrations that are typical of an open marine setting. The slight change in pore water concentrations in the deepest sediment may reflect nonsteady-state diagenetic conditions that may be due to waters advecting through the relatively permeable volcanic-rich turbidite that lies at the base of the hole; however, not all dissolved constituents necessarily support this idea, and such an assertion would require further analysis (Table T3). 
Microbiological Sample 340-U1394A-17H-3, 140$150 \mathrm{~cm}$, was taken after the piston core had been preloaded with a microsphere bag to assess potential surface contamination. A total of $20 \mathrm{~g}$ of sediment was taken for shore-based microbiological activity measurements and was stored at $0^{\circ} \mathrm{C}$. A total of $4 \mathrm{~g}$ of sediment was taken for shore-based RNA analysis and stored at $-80^{\circ} \mathrm{C}$.

\section{Physical properties}

The physical properties of Holes U1394A and U1394B were correlated with lithologic variations, including composition, grain size, and lithification. Bioclastic-volcaniclastic turbidites and thick tephra layers were distinguished from background hemipelagic sediment by most physical properties. Variable shear strength could be due to the variable facies observed within turbidite and hemipelagic sediment, resulting in different types of sediment consistency. Stratigraphic correlation reveals a systematic decrease in density and magnetic susceptibility values for Hole U1394A, where the XCB was primarily used, versus Hole U1394B, where the APC was the primary tool for extracting core.

\section{Stratigraphic correlation between Holes U1394A and U1394B}

We used both magnetic susceptibility and gamma ray attenuation (GRA) density data to correlate depths between Holes U1394A and U1394B (Fig. F7), with magnetic susceptibility providing the most robust correlation. Correlation is best in the uppermost $7 \mathrm{~m}$ of the holes, where both holes had high recovery rates. In the uppermost $7 \mathrm{~m}$ we see clear correlation of turbidite units between the two holes. Between 7 and 15 mbsf, some discrepancy exists between the holes despite the use of the APC in both holes over this interval. From 15 to 140 mbsf, correlation is more difficult and less consistent, and we attribute this inconsistency to using different coring tools at these depths and low recovery in Hole U1394A or to changes in lithology. Between 140 and $160 \mathrm{mbsf}$, both holes have higher recovery rates, and correlation is good despite different coring tools being used at these depths (XCB in Hole U1394A; APC in Hole U1394B). GRA density and magnetic susceptibility values are consistent between 140 and 160 mbsf; however, values in Hole U1394A are systematically lower than those in Hole U1394B, a difference we attribute to smaller diameter cores recovered via $\mathrm{XCB}$ drilling in Hole U1394A. The largest depth shift for the correlation picks is $2.05 \mathrm{~m}$, with most shifts $<1 \mathrm{~m}$. All 18 correlation pick depth shifts are listed in Table T4.

\section{Gamma ray attenuation density, magnetic susceptibility, and $P$-wave velocity}

We measured magnetic susceptibility, GRA bulk density, compressional wave ( $P$-wave) velocity, and natural gamma radiation (NGR) on all core sections, including those with water, air pockets, cracks, and loose clasts (Fig. F8). In the uppermost $25 \mathrm{~m}$ cored with the APC, these measurements are reliable and agree with spot measurements of density and $P$-wave velocity measured on the split core. Where the holes were drilled with the $\mathrm{XCB}$, whole-core logger measurements are less reliable because the core has a smaller diameter (usually $0.5-1.5 \mathrm{~cm}$ smaller) than the core liner. Many of the cores deeper than $25 \mathrm{mbsf}$ in Hole U1394A therefore have systematically low density and magnetic susceptibility. Measured wholecore $P$-wave velocities should only be reduced a few percent because of XCB drilling because water velocity $(\sim 1500 \mathrm{~m} / \mathrm{s})$ is comparable to shallow marine sediment velocities and the calipers squeeze the core liner, often displacing fluid from the gap between the liner and core. Additionally, the Whole-Round Multisensor Logger (WRMSL) only obtains $P$-wave velocities when good coupling exists across the core liner, with no gas or sharp water/sediment contacts. Below $25 \mathrm{mbsf}$, high-end $P$-wave values are typically $\sim 1600 \mathrm{~m} / \mathrm{s}$, consistent with spot measurements of $P$ wave velocity on the split core. For Hole U1394B, the $\mathrm{XCB}$ was used between 15 and $60 \mathrm{mbsf}$, and magnetic susceptibility and GRA density measured on whole cores are systematically low at these depths. The rest of Hole U1394B was cored with the APC.

In the uppermost $25 \mathrm{~m}$ (Units $\mathrm{A}$ and $\mathrm{B}$ ), magnetic susceptibility averaged $740 \times 10^{-5}$ SI with a maximum of $3890 \times 10^{-5} \mathrm{SI}, P$-wave velocity averaged $1614 \mathrm{~m} / \mathrm{s}$ with a maximum of $1956 \mathrm{~m} / \mathrm{s}$, density averaged $1.68 \mathrm{~g} / \mathrm{cm}^{3}$ with a maximum of $2.27 \mathrm{~g} / \mathrm{cm}^{3}$, and NGR averaged 9 counts per second (cps) with a maximum of 15 cps. Although absolute values of density, magnetic susceptibility, and $P$-wave velocity below 25 mbsf may underestimate true values, spatial variations nevertheless identify different lithologies. Typical values of magnetic susceptibility are $200 \times 10^{-5}$ to $400 \times 10^{-5}$ SI. Occasional excursions to $2000 \times 10^{-5}$ or $4000 \times 10^{-5}$ SI occur at 4.6, 11.4, 23, 66, 100, 109, 170, and 173 mbsf.

Holes U1394A and U1394B have very similar physical properties (Fig. F8). In all units, the four physical properties measured by the WRMSL correlate well and appear to be modified by similar lithostratigraphic variations. Physical properties of hemipelagic sediment show little variation and have low magnetic susceptibility and $P$-wave velocity and relatively high NGR values. Physical properties are more variable in turbidites. Single (bioclastic-)volcaniclastic 
turbiditic units throughout the cores can be traced by their monotonically decreasing magnetic susceptibility, GRA density, and $P$-wave velocity uphole, mimicking their grading in grain size (e.g., 1114 mbsf). A sharp drop in each of these values occurs at the turbidite unit boundaries. Where sufficiently thick, ash layers give positive magnetic susceptibility peaks, such as the one at 145 mbsf.

In the interval between 10 and 15 mbsf, GRA density, magnetic susceptibility, and NGR values are systematically different between the two holes and correspond to differences in lithology. In Hole U1394A, dark and dense turbidites with andesitic composition dominate; in Hole U1394B, lighter colored pumice-rich deposits dominate. Between 12.5 and 14.8 mbsf, a block of deformed hemipelagic sediment exists in Hole U1394A but is absent in Hole U1394B (Fig. F8A).

\section{Thermal conductivity}

Thermal conductivity was measured on all sections with fine-grained sediment, but only about a third of the measurements were high quality. In the uppermost $25 \mathrm{~m}$ (Fig. F8A), poor measurements may be due to water convection in pore space. In the remainder of the core, pervasive cracks and the high strength of the core made it difficult to be sure that the probe did not encounter cracks or create small cracks upon entry. The mean thermal conductivity of 44 reliable measurements was $1.03 \mathrm{~W} /(\mathrm{m} \cdot \mathrm{K})$ with a standard deviation of $0.07 \mathrm{~W} /(\mathrm{m} \cdot \mathrm{K})$ and a standard error on the mean of $0.01 \mathrm{~W} /(\mathrm{m} \cdot \mathrm{K})$.

\section{Shear strength}

Handheld penetrometer strengths ranged from 7 to $>220 \mathrm{kPa}$ (the upper value being the maximum that can be measured by the probe). Measurements for sandy units are not reliable because the grain size was large enough that the test was probably not probing undrained conditions. Excluding the unreliable measurements, the mean for the upper $7 \mathrm{~m}$ is $7 \mathrm{kPa}$, whereas shear strength varies between 70 and $>220 \mathrm{kPa}$ at greater drilled depths (Fig. F8).

Higher shear strength measurements are obtained from the handheld penetrometer compared to those provided by the automated vane shear (AVS) apparatus and the fall cone. The AVS could only be used in relatively soft, cohesive sediment where insertion of the probe did not create cracks, constraining the measurements to muddy, soft, fine-grained sediment.

The fall cone recorded shear strengths as low as $10 \mathrm{kPa}$ at 14 mbsf and as high as $300 \mathrm{kPa}$ at 149 mbsf. Because of scattered data for the uppermost $100 \mathrm{~m}$, no trend could be identified. We did not observe a linear increase in shear strength with depth found in normally consolidated marine sediment. The fall cone and the AVS provided highly variable values between 20 and $125 \mathrm{kPa}$ from 110 mbsf to the bottom of the holes.

\section{$\boldsymbol{P}$-wave velocity}

In the split cores we obtained 128 measurements of $x$-axis and 26 measurements of $z$-axis $P$-wave velocity using the caliper apparatus (Fig. F8). Caliper measurements agree with $P$-wave measurements made on the full core (WRMSL); however, caliper velocity values in coarse-grained volcaniclastic sediment are generally higher. Higher caliper $P$-wave velocities on coarse-grained sediment compared to the WRMSL may be the result of dewatering following splitting.

We conducted $x$-axis caliper $P$-wave measurements on most split cores. However, $z$-axis measurements could only be carried out in loose sediment, where the bayonet could enter the split core without damaging the core structure. $Z$-axis measurements were commonly noisy, with most values close to $1680 \mathrm{~m} / \mathrm{s}$. $Z$-axis $P$-wave measurements do not always match $x$-axis and WRMSL values. In the uppermost $25 \mathrm{~m}$, $P$-wave velocities increase significantly from $\sim 1600$ to $2000 \mathrm{~m} / \mathrm{s}$ across volcaniclastic turbiditic units. In each unit, the base is coarse grained and has the highest $P$-wave velocity, whereas the fine-grained upper parts have the lowest $P$-wave velocities.

\section{Moisture and density}

We collected 48 moisture and density (MAD) samples (31 from Hole U1394A and 17 from Hole U1394B) (Fig. F8), including 28 from hemipelagic sediment, 18 from turbidites, and one from carbonate sand. Porosity of hemipelagic sediment ranges from $48 \%$ to $66 \%$. Turbidites have porosities between $42 \%$ and $60 \%$. The porosity of hemipelagic sediment generally decreases with depth.

Bulk density of hemipelagic sediment ranges from 1.52 to $1.85 \mathrm{~g} / \mathrm{cm}^{3}$; bulk density of turbidites ranges from 1.65 to $2.08 \mathrm{~g} / \mathrm{cm}^{3}$. No systematic difference is apparent in porosity and bulk density between volcaniclastic and mixed bioclastic-volcaniclastic turbidites.

Grain density of hemipelagic samples typically ranges between 2.63 and $2.79 \mathrm{~g} / \mathrm{cm}^{3}$, with three outliers between 2.10 and $2.28 \mathrm{~g} / \mathrm{cm}^{3}$. Grain density of turbidites ranges between 2.6 and $2.9 \mathrm{~g} / \mathrm{cm}^{3}$.

\section{Paleomagnetism}

Cores 340-U1394A-1H through $3 \mathrm{H}$ were recovered with the APC using nonmagnetic core barrels. All other APC cores were recovered using standard steel core barrels. The FlexIt core orientation tool was 
used on all APC cores recovered with nonmagnetic barrels; thus, between 0 and 24 mbsf in Hole U1394A declination can be corrected to true north. Where FlexIt tool data were not available, declination was guided by the discrete inclination data (see "Paleomagnetism" in the "Methods" chapter [Expedition 340 Scientists, 2013]). Expected inclination for the site is $30.0^{\circ}$ during normal polarity and $-30.0^{\circ}$ during reversed polarity, assuming a geocentric axial dipole (GAD). Archive halves of cores from Holes U1394A and U1394B were measured on the threeaxis superconducting rock magnetometer (SRM) at $2.5 \mathrm{~cm}$ intervals (Table T5). NRM was measured before $\left(\mathrm{NRM}_{0}\right)$ and after stepwise alternating field demagnetization (NRM FIELD in $\mathrm{mT}_{\text {T }}$ in peak fields as high as $20 \mathrm{mT}$. Core $340-\mathrm{U} 1394 \mathrm{~A}-1 \mathrm{H}$ and Sections 340U1394A-2H-1A through $3 \mathrm{H}$ were measured at

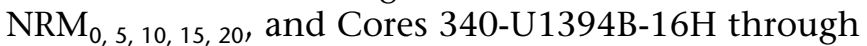
$21 \mathrm{H}$ were measured at $\mathrm{NRM}_{0,15,20}$. All other sections were measured at $\mathrm{NRM}_{0,10,15,20}$. Twenty discrete samples were collected from the center of the working half of the core for to compare to the SRM data (see "Paleomagnetism" in the "Methods" chapter [Expedition 340 Scientists, 2013]).

Sediment recovered from Site U1394 is very heterogeneous in composition and varied between layers of hemipelagic sedimentation to deposits related to volcanic activity and volcanic turbidites (see "Lithostratigraphy"). Using the detailed core description logs we only interpreted data measured on identifiable hemipelagic layers (red/orange directional data; Figs. F9, F10), as these appear the least disturbed and are more likely information related to the behavior of the geomagnetic field.

\section{Results}

Cores 340-U1394A-1H through $3 \mathrm{H}$ show scattered but expected inclination for the site, assuming a GAD, clustering around $30^{\circ}$ (Fig. F9). APC cores recovered with steel barrels and cores recovered with the $\mathrm{XCB}$ possess steeper than GAD inclinations, possibly suggesting a drilling overprint that remains after alternating field (AF) demagnetization in a field of $20 \mathrm{mT}$. Discrete samples show two magnetic components: a softer component, typically removed by demagnetization in fields of 10-15 $\mathrm{mT}$, and a secondary ChRM component that trends toward the origin (Fig. F11). After demagnetization at $20 \mathrm{mT}$, the inclination of the discrete samples is shallower than the corresponding SRM inclination despite similar normalized demagnetization ratios. Discrete cubes taken in the center of the working half may be more protected from drilling-related magnetic overprints (Richter et al., 2007) than the whole-section SRM data. The data from Site U1394 suggests that the steep inclination seen in the SRM records recovered in standard steel barrels may be related to acquisition of an isothermal remanent magnetization (IRM) related to the coring process (e.g., Fuller et al., 2006) that is not removed by AF demagnetization in a field of $20 \mathrm{mT}$. Coring deformation around the edges of the APC and XCB can also potentially explain the inclination steepening (Fuller et al., 2006). However, data from nonmagnetic barrels do not show the same level of discrepancy between the SRM and discrete data, suggesting that these overprints result from the barrel type used and that the sediment in the center of the core is more protected from this overprint.

Intensity at $\mathrm{NRM}_{0}$ and $\mathrm{NRM}_{20}$, inclination at $\mathrm{NRM}_{20}$, and, for Cores 340-U1394A-1H and 2H with FlexIt tool data, corrected declination at $\mathrm{NRM}_{20}$ is shown in Figures F9 and F10. Inclination of the 20 discrete samples demagnetized at $20 \mathrm{mT}$ are plotted as black squares. As at other sites, $\mathrm{NRM}_{0}$ intensity shows a similar signature to magnetic susceptibility (see "Physical properties"). These parameters, particularly magnetic susceptibility, are strongly related to the concentration of ferrimagnetic minerals (e.g., magnetite and correlate well with depositional units of volcanic origin) (see "Core descriptions").

SRM data all show steep but normal polarity; all 19 discrete hemipelagic samples spaced over both holes also record normal polarity clustering around a GAD-like inclination. Nannofossil and foraminiferal datums give the sediment a Pleistocene age (see "Paleontology and biostratigraphy"). We see no evidence for reversed polarity in the record, particularly in the lower part of the record where data coverage is better. Because of the lack of a continuous record, we cannot unequivocally say that all sediment was deposited within the Brunhes chron; however, this would indicate a late Pleistocene age for the site, which agrees with biostratigraphic ages.

\section{Downhole logging}

A $100 \mathrm{~m}$ section of Hole U1394B was successfully logged with two tool strings over a period of $\sim 16.5 \mathrm{~h}$. The downhole logging measurements obtained include total and spectral gamma ray, electrical resistivity and images, magnetic susceptibility, and velocity. The borehole remained in good condition for the duration of the logging operations.

\section{Operations}

Downhole logging operations in Hole U1394B commenced on 12 March 2012 at $0520 \mathrm{~h}$ (UTC - $4 \mathrm{~h}$ ) following APC/XCB coring operations, which were terminated at a total depth of 181.4 mbsf. The hole 
was prepared for logging by sweeping with high viscosity mud, displacing the hole with heavy mud, and pulling the pipe to a bit depth of 82.7 mbsf.

Three tool strings were deployed in Hole U1394B (Fig. F12): (1) the triple combo-Magnetic Susceptibility Sonde (MSS), (2) the VSI, and (3) the FMS-sonic (see Fig. F11 in the "Methods" chapter [Expedition 340 Scientists, 2013]). The first deployment was of the triple combo-MSS tool string, made up of the Hostile Environment Natural Gamma Ray Sonde (HNGS), Hostile Environment Litho-Density Sonde (HLDS), High-Resolution Laterolog Array (HRLA), and MSS (see "Downhole logging" in the "Methods" chapter [Expedition 340 Scientists, 2013] for tool string details). Owing to concerns regarding hole stability, the ${ }^{137} \mathrm{Cs}$ source was omitted from the HLDS, so no density data were recorded. The tool string was lowered into the hole at $0710 \mathrm{~h}$ on $12 \mathrm{March}$, completing a downlog to a total depth of $180 \mathrm{mbsf}$. An initial uplog to 110.5 mbsf was completed, followed by a second and final uplog from 180 mbsf terminating above the seafloor. The triple combo was rigged down by $1145 \mathrm{~h}$.

The second deployment was the VSI tool string. Rig up for this VSP experiment started at $1145 \mathrm{~h}$, and the associated protected species watch commenced at $1130 \mathrm{~h}$. The VSI tool string was lowered into the hole at $1230 \mathrm{~h}$. Unfortunately, the tool string never cleared the BHA. Following various failed attempts at pumping the tool down through the BHA, the experiment was abandoned at $1450 \mathrm{~h}$ and the tool string rigged down by $1545 \mathrm{~h}$.

The final deployment in Hole U1394B was the FMSsonic tool string. The tool string was lowered into the hole at $1800 \mathrm{~h}$, reaching a total depth of $180 \mathrm{mbsf}$ at $1902 \mathrm{~h}$. Two passes of the open hole section were then conducted, after which the tool string was returned to the surface, where rig down was completed by $2140 \mathrm{~h}$.

\section{Data processing and quality assessment}

Logging data for Hole U1394B are summarized in Figures F13, F14, and F15. Initially logging data were depth-shifted to the seafloor as identified by a stepwise increase in the gamma ray value. Depth shifts were then applied to the logging data by using the total gamma ray log from the main pass of the triple combo as a reference log. Features in gamma ray logs from the other tool string passes were aligned to the reference log to produce a complete depth-matched data set.

Hole diameter was recorded by the hydraulic caliper on the HLDS and by the FMS calipers (Figs. F13, F14). All caliper measurements indicate an in-gauge hole with a diameter ranging from 11.2 to 15.8 inches (mean $=12.7$ inches). The widest part of the hole was observed in the upper portion just below the pipe, between $\sim 87$ and 93 mbsf. These measurements were relatively consistent throughout the course of the logging program. Comparisons between repeat passes for each of the tool strings indicate a good degree of repeatability for all measurements (Fig. F16).

The Dipole Shear Sonic Imager (DSI) was operated in the following modes: P\&S monopole and upper and lower dipole for both passes. To optimize measurements in this soft sediment, the monopole and upper dipole utilized a standard (high) frequency and a lower frequency was used for the lower dipole. The resulting slowness data were subsequently converted to acoustic velocities (compressional wave velocity [ $V_{\mathrm{p}}$; monopole] and shear velocity $\left[V_{\mathrm{S}}\right.$; upper and lower dipole]). The high coherence in sonic waveforms indicated by distinctive red areas in the $V_{\mathrm{p}}$ and $V_{S}$ tracks (Fig. F14) suggests that the DSI was able to capture both compressional and flexural arrivals. However, in the interval between 90 and 105 mbsf the automatic labeling of the wave arrivals (black curve) failed to recognize the shear wave, and thus the data in this interval should not be interpreted. Additional postcruise processing will refine the $V_{S}$ profile and provide a better estimate of shear velocity in the poorly labeled interval.

Good FMS image quality relies on a number of factors, including an in-gauge hole, regular borehole walls, and good contact between the tool's pads and the borehole wall. Hole U1394B was in gauge, and the FMS pads seem to have maintained good contact with the borehole walls while the calipers were open. However, there was a $6 \mathrm{~m}$ section between $\sim 99$ and 106 mbsf where the calipers were closed because of excessive sticking (evidenced by increased tension on the wireline cable) over which no images were recorded. Processing of the FMS image data allows a speed correction to be applied that takes account of variations in the speed of the tool including stick and slip. The shifts applied on this basis were within acceptable limits $(<1 \mathrm{~m})$.

\section{Logging stratigraphy}

Although there are characteristic trends in the logging data from Hole U1394B, there are not enough large-scale differences over the $100 \mathrm{~m}$ interval of the open hole to warrant subdivision into multiple logging units. The entire logged interval was assigned to one logging unit (Figs. F13, F14, F15). Logging Unit 1 extends from 80 to 180 mbsf. Variations in logging measurements within the unit are described in detail below. 


\section{Logging Unit 1}

The gamma ray profile in logging Unit 1 is characterized by low-amplitude, high-frequency changes in the uppermost $10 \mathrm{~m}$ and relatively higher amplitude, lower frequency changes below that. Consideration of lower amplitude variations below $100 \mathrm{mbsf}$ suggests that there are peak-to-peak changes in gamma ray across 5-10 $\mathrm{m}$ intervals (Fig. F13). Overall gamma ray increases with depth and has an average value of $19 \mathrm{gAPI}$ with a mean potassium concentration of $0.32 \%$ (standard deviation $=0.08$ ). There is some suggestion from the spectral data that uranium $($ mean $=0.97 \mathrm{ppm})$ and thorium $($ mean $=1.80 \mathrm{ppm})$ are anticorrelated, particularly in the lower portion of the logged section (Fig. F15). A net increase in resistivity from 80 to $100 \mathrm{mbsf}$ is followed by a subtle decrease to the base of the hole, a trend that is echoed in the magnetic susceptibility data set. True resistivity values range from 0.01 to $2.45 \Omega \mathrm{m}$, with a mean of $1.33 \Omega \mathrm{m}$ (Fig. F13). Through the logged section there are a number of resistivity highs on the scale of $\sim 1-2 \mathrm{~m}$. These, like the general trend, correspond with magnetic susceptibility highs (Fig. F17), and, as expected, the resistivity logs relate well to the FMS images (Fig. F14, F18).

The magnetic susceptibility data set provides the best coverage of Hole U1394B because of its position at the base of the triple combo (see Fig. F11 in the "Methods" chapter [Expedition 340 Scientists, 2013]). The data are given in uncalibrated units and are therefore most useful when used in tandem with a calibrated data set, such as the core magnetic susceptibility data from the multisensor loggers. Downhole magnetic susceptibility logs indicate two intervals of higher amplitude variations, the first between $~ 93$ and 105 mbsf and the second between $160 \mathrm{mbsf}$ and the base of the hole. Individual high-amplitude features in magnetic susceptibility and resistivity correspond, in some cases, to debris deposits and volcaniclastic sand and turbidites (Fig. F17). This correspondence is generally consistent with magnetic susceptibility loop data from the whole core. The interval from 105 to 160 mbsf exhibits lower amplitude variations, and overall magnetic susceptibility decreases downhole.

Similar to the gamma ray data, $V_{\mathrm{p}}$ measurements from sonic $\log$ data generally increase downhole, ranging from $\sim 1650$ to $1900 \mathrm{~m} / \mathrm{s}$. These downhole $V_{\mathrm{P}}$ measurements are generally higher than those measured on the cores recovered from Hole U1394B (typically $\sim 1600 \mathrm{~m} / \mathrm{s}$; see "Physical properties"). There are distinctive localized peaks in $V_{\mathrm{p}}$ between $\sim 90$ and 120 mbsf that coincide with increased resistivity and magnetic susceptibility (Figs. F13, F14). These features likely correspond to similarly scaled turbidites identified in the cores (see "Lithostratigraphy"). In the interval below $105 \mathrm{mbsf}, V_{\mathrm{P}}$ and $V_{\mathrm{S}}$ show similar characteristics.

\section{Formation MicroScanner images}

Examples of the FMS images from Hole U1394B are shown in Figure F18. The images show local smallscale changes in the sediment's electrical properties that may be related to subtle changes in sediment hardness and/or clay content. In addition to subtle changes, there are also some very definite boundaries evident in the images that are marked by strong resistivity contrasts (Figs. F17, F18). Most of the boundaries identified are subhorizontal in orientation; however, a few appear to be dipping.

Correlation of the logging data and images to the corresponding core measurements suggests that the data sets are offset on the order of a few meters (Fig. F17). Although some offset is expected because of the different measurements of depth (wireline versus core), this larger offset may be due to coring artifacts/ expansion or related to wireline cable stretch.

\section{References}

Bouma, A.H., 1962. Sedimentology of Some Flysch Deposits: A Graphic Approach to Facies Interpretation: Amsterdam (Elsevier).

Clavero, J., Sparks, R., Huppert, H., and Dade, W., 2002. Geological constraints on the emplacement mechanism of the Parinacota debris avalanche, northern Chile. Bull. Volcanol., 64(1):40-54. doi:10.1007/s00445-001-0183-0

Devine, J.D., Rutherford, M.J., and Gardner, J.E., 1998. Petrologic determination of ascent rates for the 1995-1997 Soufriere Hills Volcano andesitic magma. Geophys. Res. Lett., 25(19):3673. doi:10.1029/98GL00912

Expedition 340 Scientists, 2013. Methods. In Le Friant, A., Ishizuka, O., Stroncik, N.A., and the Expedition 340 Scientists, Proc. IODP, 340: Tokyo (Integrated Ocean Drilling Program Management International, Inc.). doi:10.2204/iodp.proc.340.102.2013

Fuller, M., Molina-Garza, R., Touchard, Y., and Kidane, T., 2006. Paleomagnetic records from carbonate legs in the Southern Oceans and attendant drilling and coring related effects. In Sager, W.W., Acton, G.D., Clement, B.M., and Fuller, M. (Eds.), ODP Contributions to Paleomagnetism. Phys. Earth Planet. Int., 156(3-4):242-260. doi:10.1016/j.pepi.2005.08.007

Gartner, S., 1977. Calcareous nannofossil biostratigraphy and revised zonation of the Pleistocene. Mar. Micropaleontol., 2:1-25. doi:10.1016/0377-8398(77)90002-0

Gee, M.J.R., Masson, D.G., Watts, A.B., and Allen, P.A., 1999. The Saharan debris flow: an insight into the mechanics of long runout submarine debris flows. Sedimentology, 46(2):317-335. doi:10.1046/j.13653091.1999.00215.x 
Glicken, H., 1991. Sedimentary architecture of large volcanic-debris avalanches. In Fisher, R.V., and Smith, G.A. (Eds.), Sedimentation in Volcanic Settings: Spec. Publ.SEPM (Soc. Sediment. Geol.), 45:99-106. doi:10.2110/ pec.91.45.0099

Glicken, H., 1996. Rockslide-debris avalanche of May 18, 1980, Mount St. Helens Volcano, Washington. Open-File Rep.-U. S. Geol. Surv., 96-677. http://vulcan.wr.usgs.gov/ Projects/Glicken/OFR96-677.pdf

Komorowski, J.-C., Glicken, H.X., and Sheridan, M.F., 1991. Secondary electron imagery of microcracks and hackly fracture surfaces in sand-size clasts from the 1980 Mount St. Helens debris-avalanche deposit: implications for particle-particle interactions. Geology, 19(3):261-264. doi:10.1130/00917613(1991)019<0261:SEIOMA>2.3.CO;2

Le Friant, A., Lock, E.J., Hart, M.B., Boudon, G., Sparks, R.S.J., Leng, M.J., Smart, C.W., Komorowski, J.C., Deplus, C., and Fisher, J.K., 2008. Late Pleistocene tephrochronology of marine sediments adjacent to Montserrat, Lesser Antilles volcanic arc. J. Geol. Soc. (London, U. K.), 165(1):279-289. doi:10.1144/001676492007-019

Lebas, E., Le Friant, A., Boudon, G., Watt, S.F.L., Talling, P.J., Feuillet, N., Deplus, C., Berndt, C., and Vardy, M.E., 2011. Multiple widespread landslides during the longterm evolution of a volcanic island: insights from highresolution seismic data, Montserrat, Lesser Antilles. Geochem., Geophys., Geosyst., 12(5):Q05006. doi:10.1029/ 2010GC003451

Okada, H., and Bukry, D., 1980. Supplementary modification and introduction of code numbers to the low-latitude coccolith biostratigraphic zonation (Bukry, 1973; 1975). Mar. Micropaleontol., 5:321-325. doi:10.1016/03778398(80)90016-X

Richter, C., Acton, G., Endris, C., and Radsted, M., 2007. Handbook for shipboard paleomagnetists. ODP Tech. Note, 34. doi:10.2973/odp.tn.34.2007

Shea, T., van Wyk de Vries, B., and Pilato, M., 2008. Emplacement mechanisms of contrasting debris avalanches at Volcán Mombacho (Nicaragua), provided by structural and facies analysis. Bull. Volcanol., 70(8):899921. doi:10.1007/s00445-007-0177-7

Voight, B., Komorowski, J.-C., Norton, G.E., Belousov, A.B., Belousova, M., Boudon, G., Francis, P.W., Franz, W., Heinrich, P., Sparks, R.S.J., and Young, S.R., 2002. The 26 December (Boxing Day) 1997 sector collapse and debris avalanche at Soufrière Hills Volcano, Montserrat. Mem.-Geol. Soc. London, 21(1):363-407. doi:10.1144/ GSL.MEM.2002.021.01.17

Watt, S.F.L., Talling, P.J., Vardy, M.E., Heller, V., Hühnerbach, V., Urlaub, M., Sarkar, S., Masson, D.G., Henstock, T.J., Minshull, T.A., Paulatto, M., Le Friant, A., Lebas, E., Berndt, C., Crutchley, G.J., Karstens, J., Stinton, A.J., and Maeno, F., 2012. Combinations of volcanic-flank and seafloor-sediment failure offshore Montserrat, and their implications for tsunami generation. Earth Planet. Sci. Lett., 319-320:228-240. doi:10.1016/ j.eps1.2011.11.032

Publication: 17 August 2013 MS 340-104 
Figure F1. Site U1394 maps. A. Shaded image of topography-bathymetry, chaotic deposits (interpreted as debris avalanche deposits), and drill sites, Expedition 340. DAD = debris avalanche deposit. (Continued on next page.)

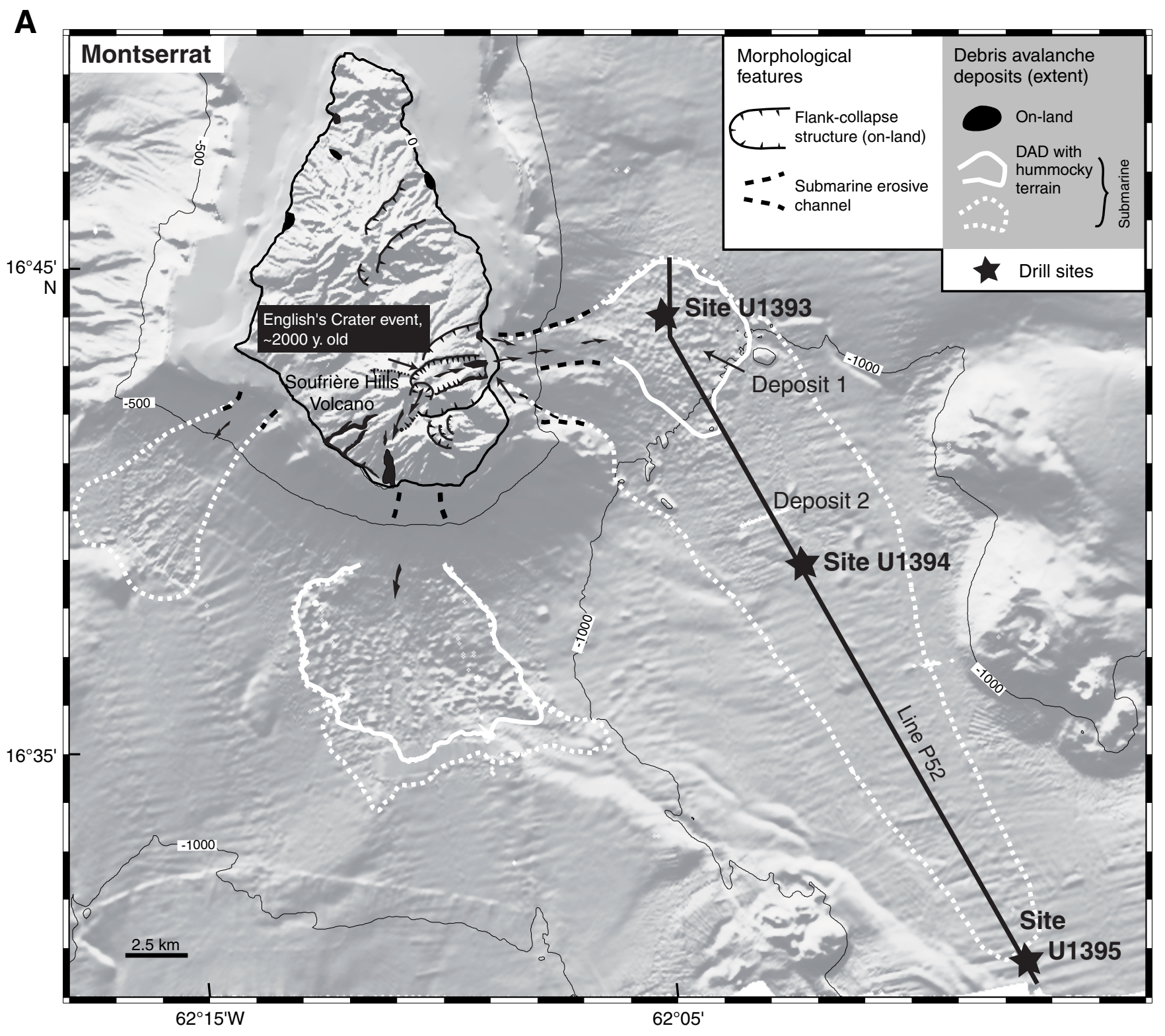


Figure F1 (continued). B. Location of seismic reflection lines, Site U1394. CDP = common depth point.

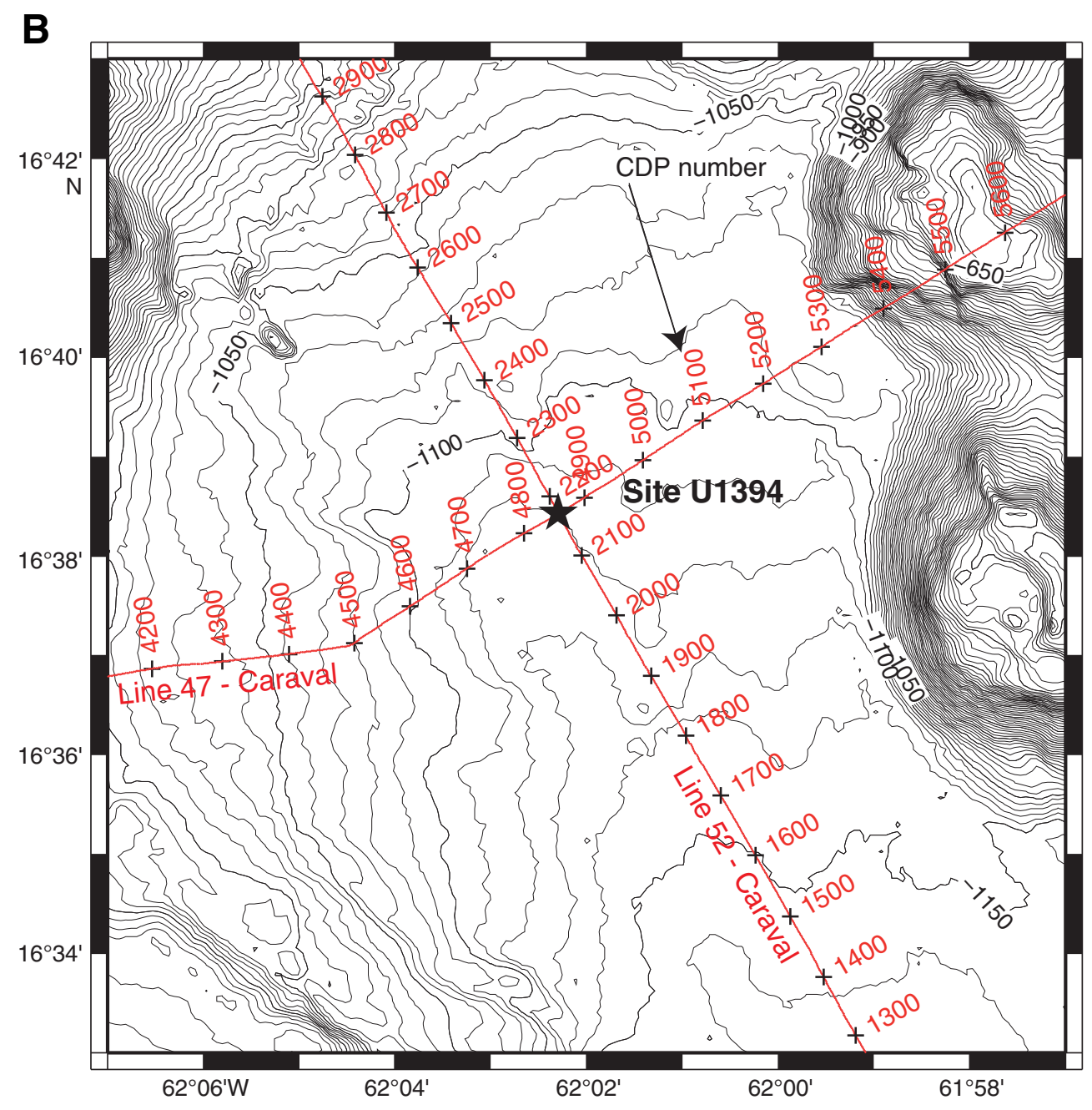


Figure F2. Section Half Image Logger (SHIL) photographs of Site U1394 core sections to illustrate common lithologies. A. Hemipelagic clay. Note dark green altered clay layers, which may be sharp or diffuse. B. Set of turbidite sequences. Fining-upward trends are indicated by arrows. C. Mafic volcaniclastic deposit (MV).

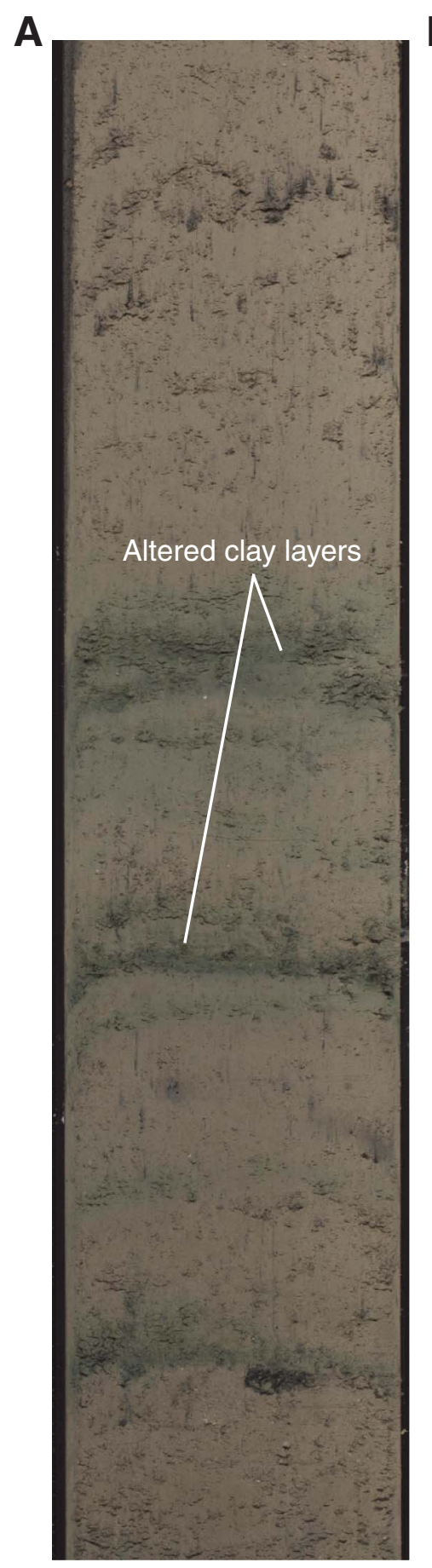

B

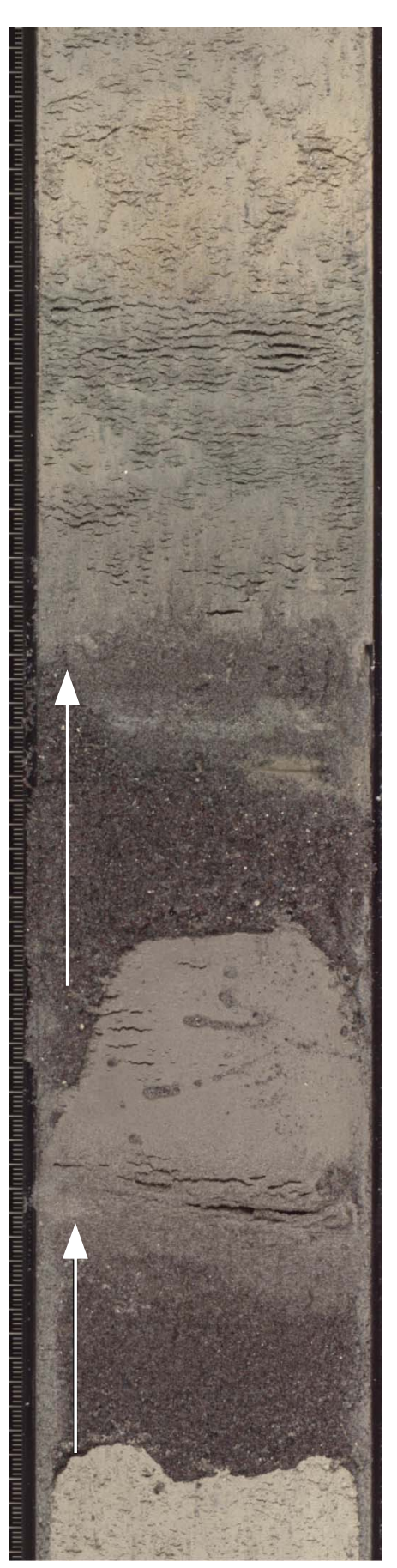

C

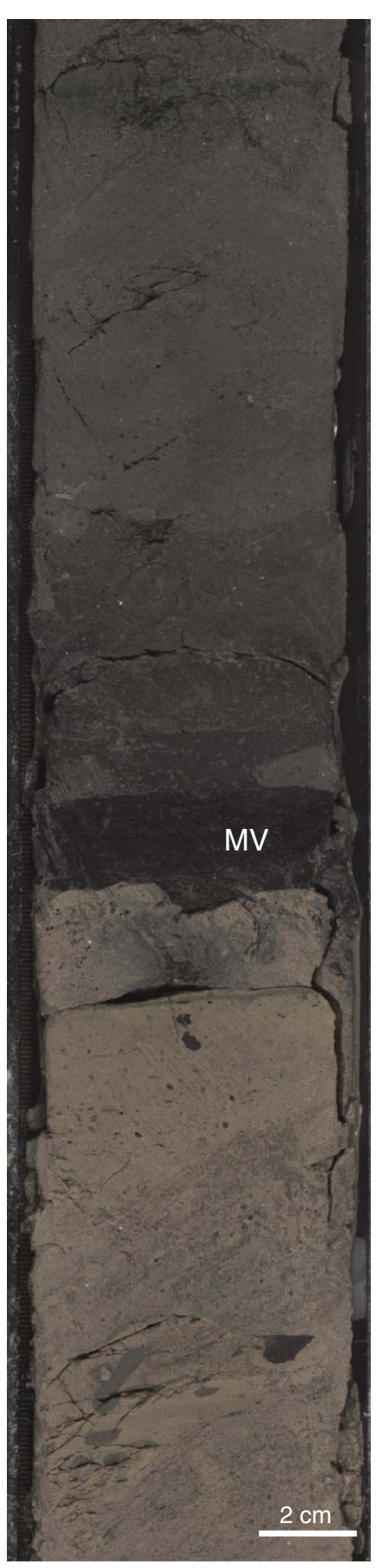


Figure F3. Integrated nannofossil and planktonic foraminiferal biozonation, Site U1394.

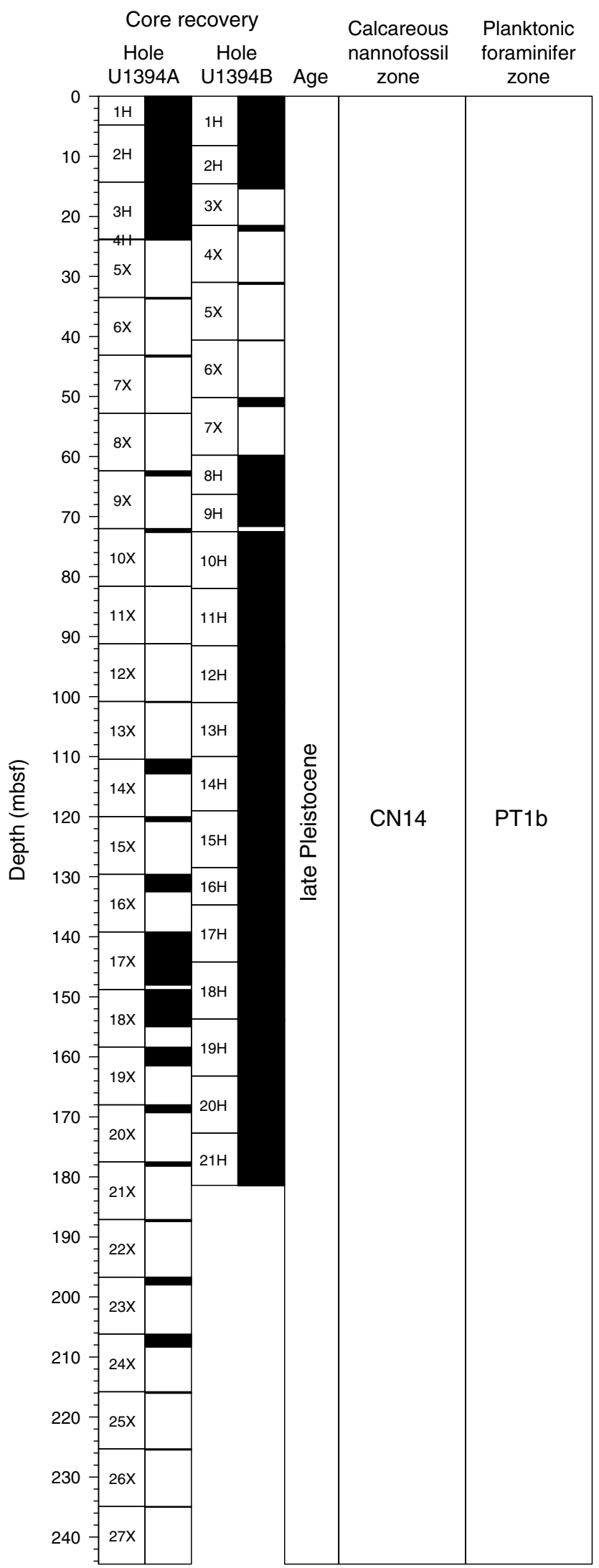




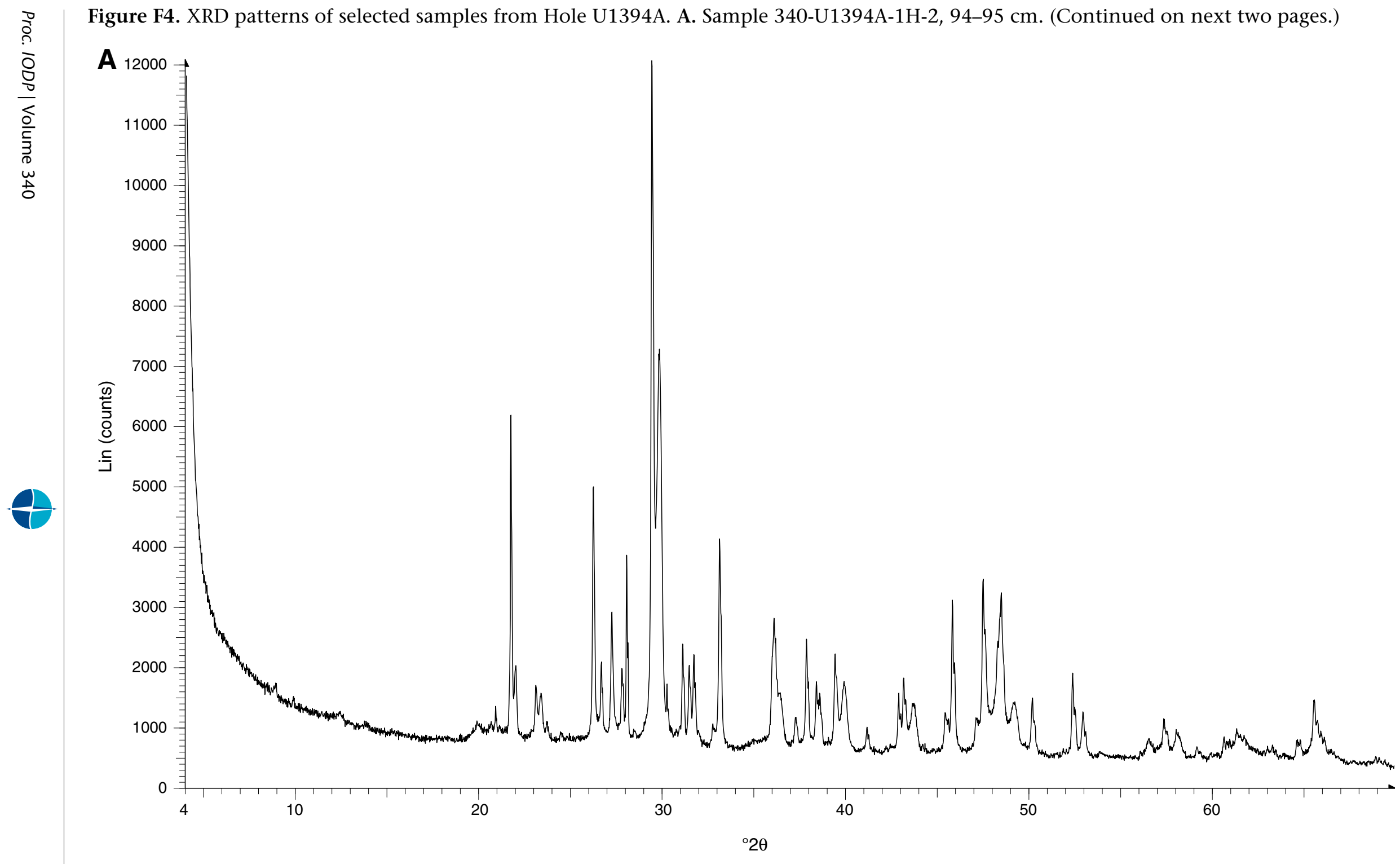




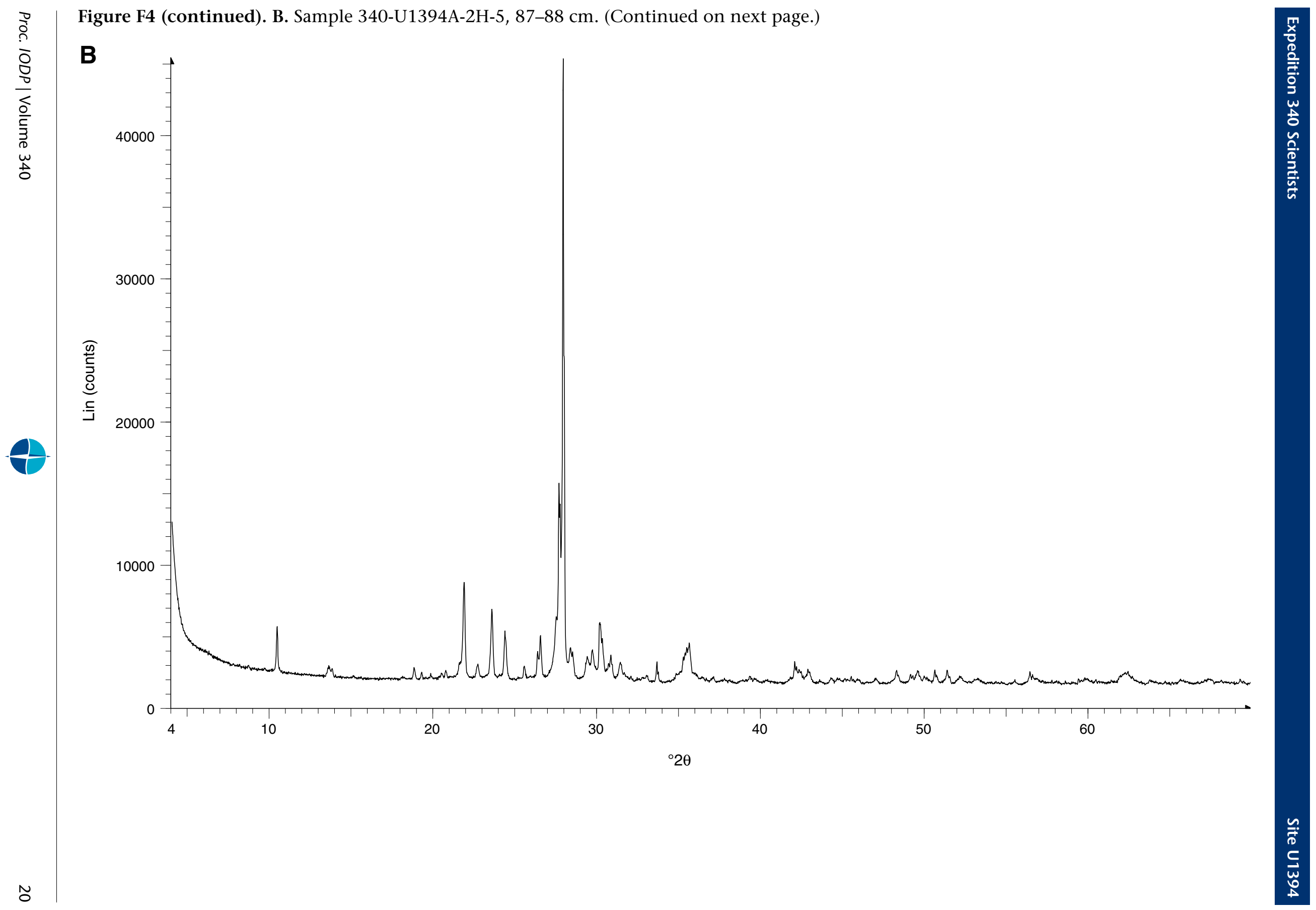




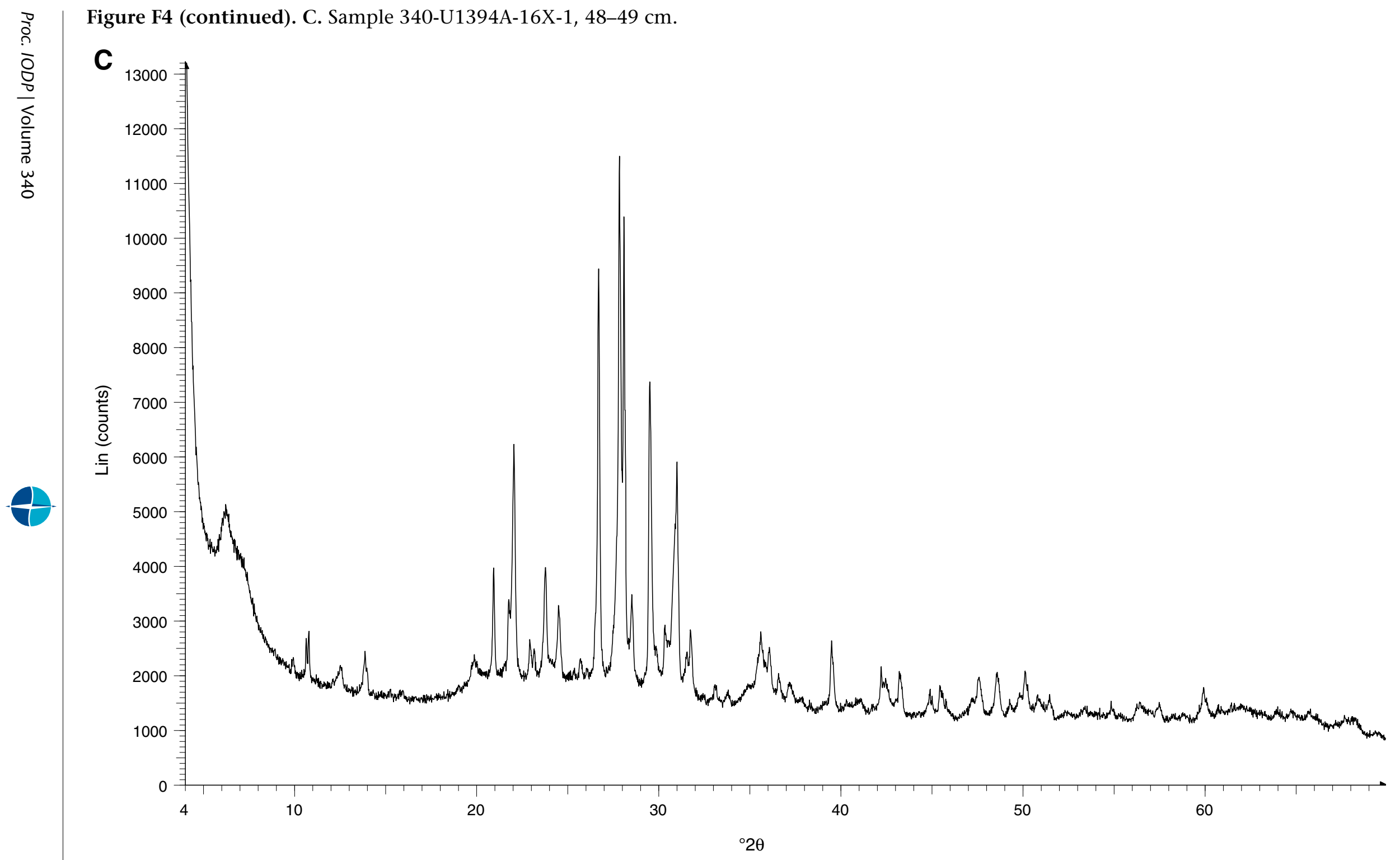


Figure F5. Solid-phase geochemical depth profiles, Hole U1394A. A. CaCO . B. Organic carbon.
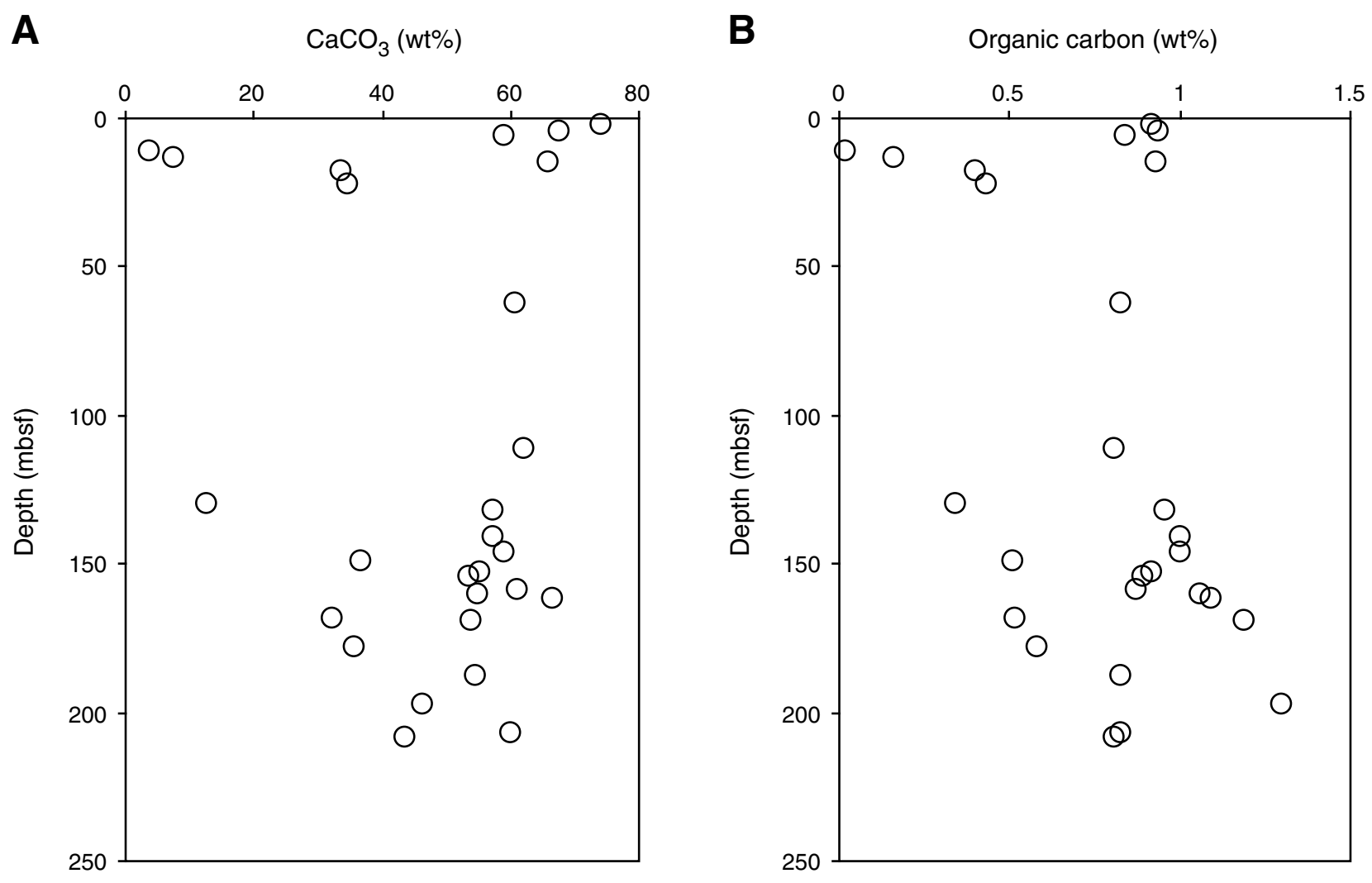


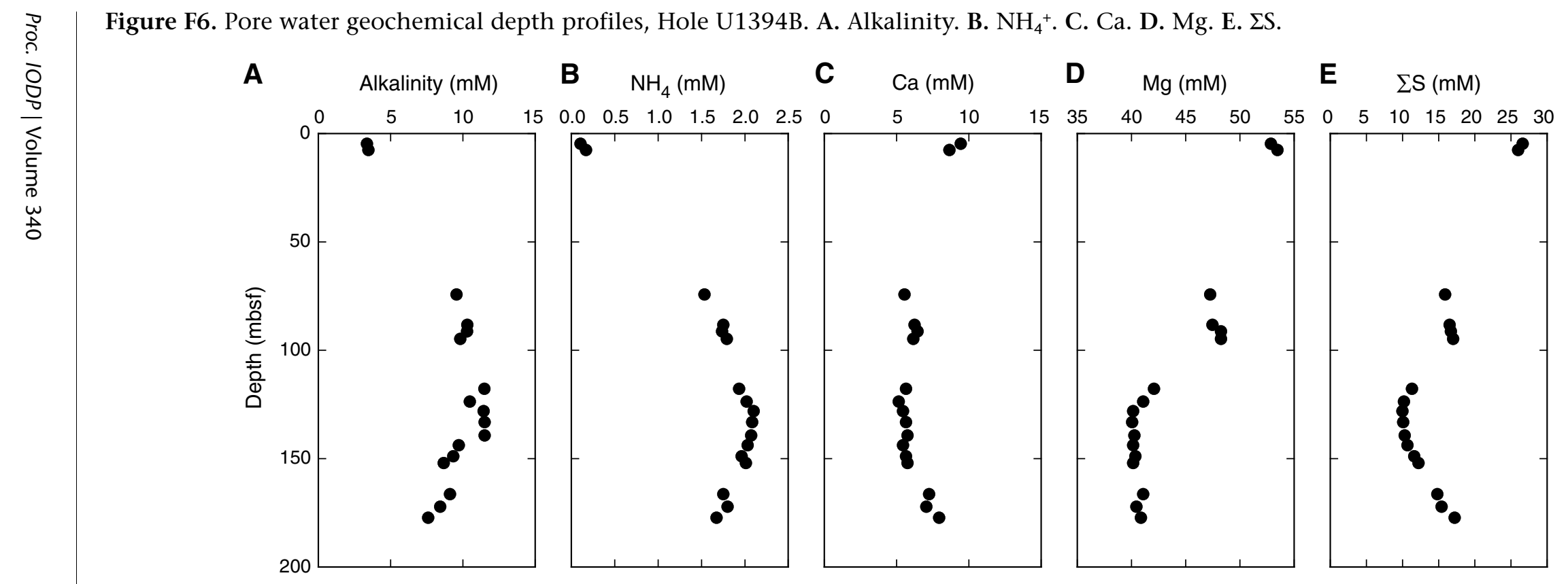


Figure F7. Magnetic susceptibility correlation, Hole U1394A (red) to Hole U1394B (blue). Magnetic susceptibility was measured on the Whole-Round Multisensor Logger (WRMSL). Capital letters and horizontal dashed lines indicate units and unit boundaries, respectively. A. 0-20 mbsf. (Continued on next page.)

A
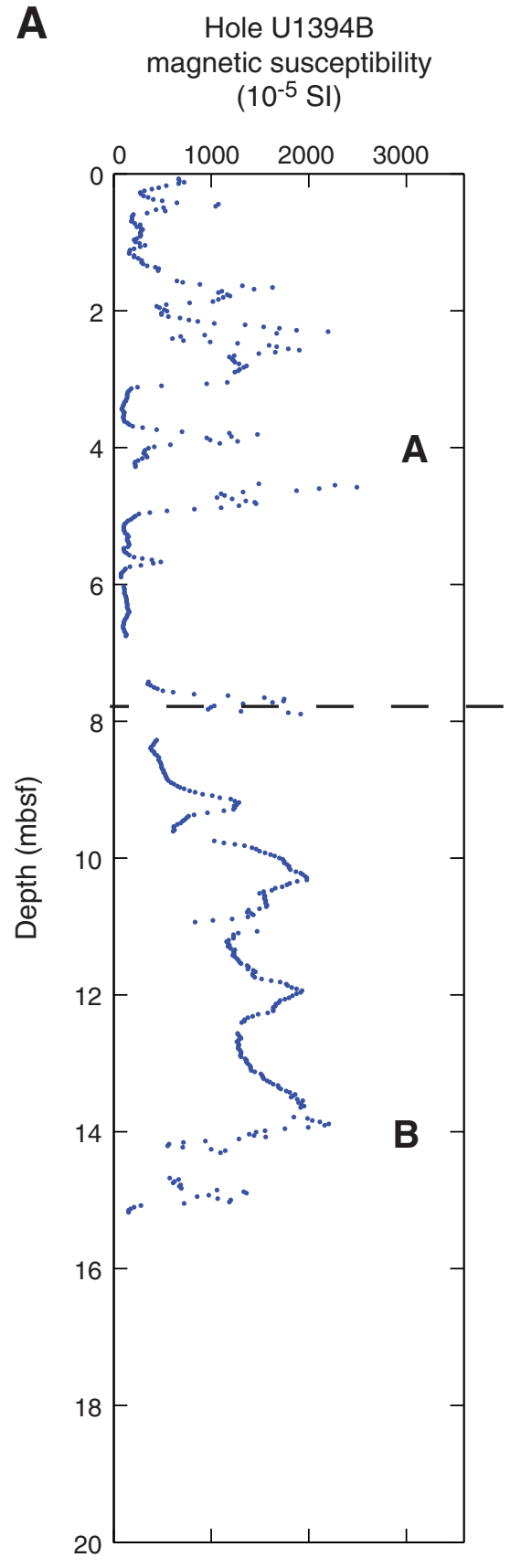
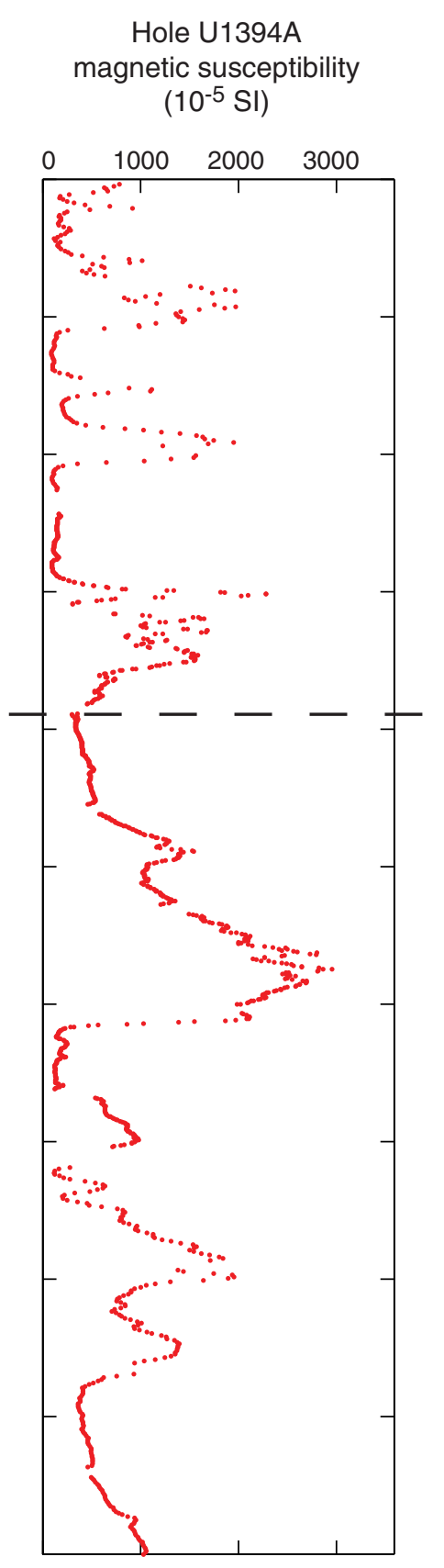

Correlated magnetic susceptibility Hole U1394A to Hole U1394B $\left(10^{-5} \mathrm{SI}\right)$

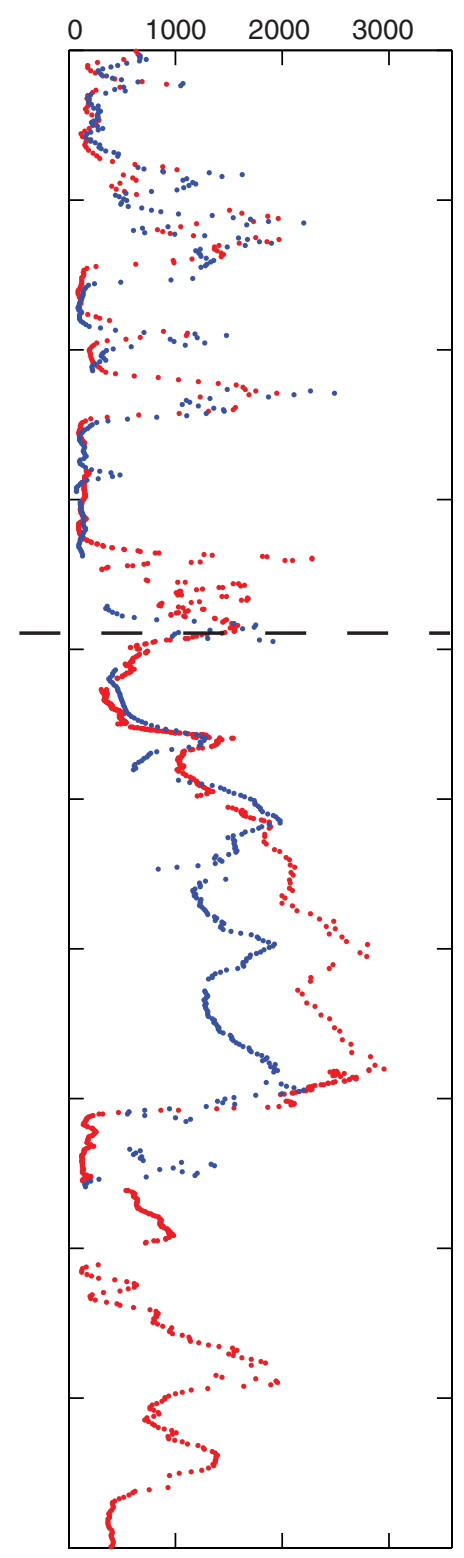


Figure F7 (continued). B. 100-180 mbsf.

B

Hole U1394B magnetic susceptibility $\left(10^{-5} \mathrm{SI}\right)$

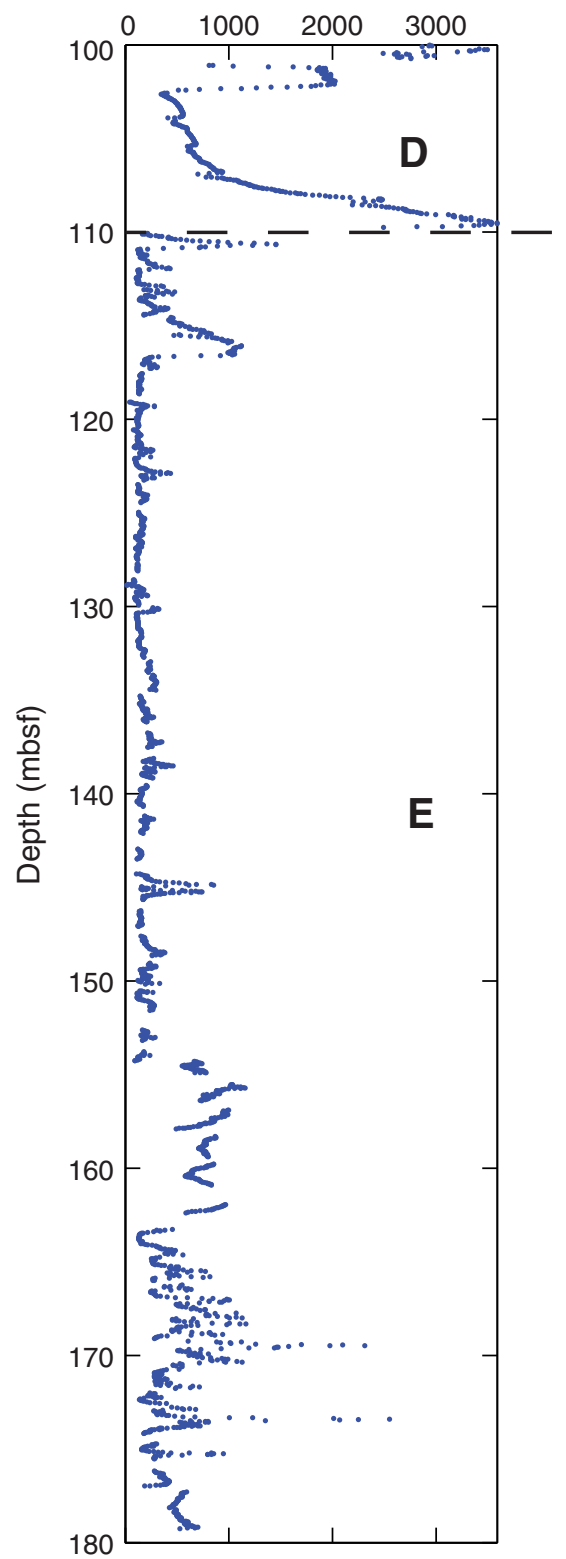

Hole U1394A magnetic susceptibility $\left(10^{-5} \mathrm{SI}\right)$

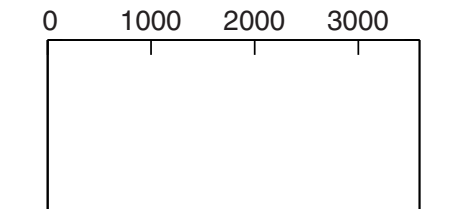

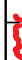

3

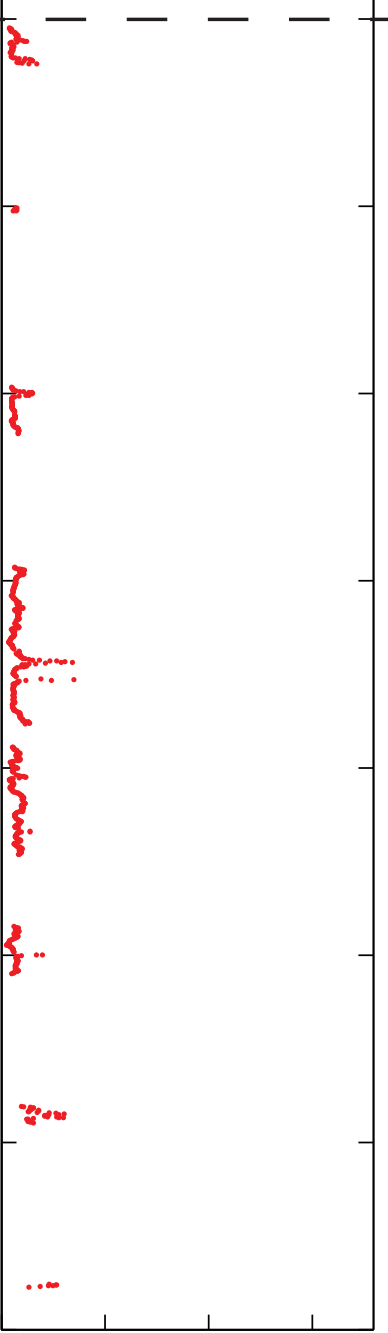

Correlated magnetic susceptibility Hole U1394A to Hole U1394B

$\left(10^{-5} \mathrm{SI}\right)$

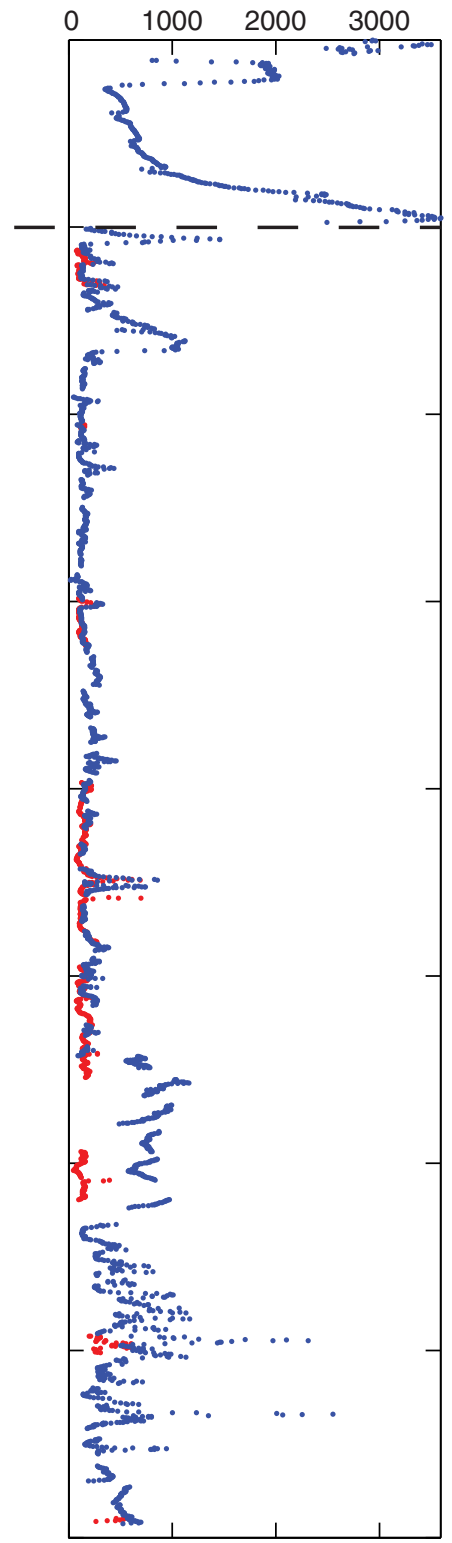


Figure F8. Physical properties, Holes U1394A (red) and U1394B (blue). Whole-Round Multisensor Logger (WRMSL) $P$-wave velocities below $1500 \mathrm{~m} / \mathrm{s}$ are not reported. Discrete point measurements are shown with larger symbols. Vertical dashed line in shear strength plot shows the maximum value that can be measured with the handheld penetrometer $(220 \mathrm{kPa})$. Capital letters and horizontal dashed lines indicate units and unit boundaries, respectively. AVS = automated vane shear. A. 0-25 mbsf. (Continued on next page.)

A

Density Magnetic susceptibility Natural gamma

$P$-wave velocity $(\mathrm{m} / \mathrm{s})$

Shear strength $(\mathrm{kPa})$
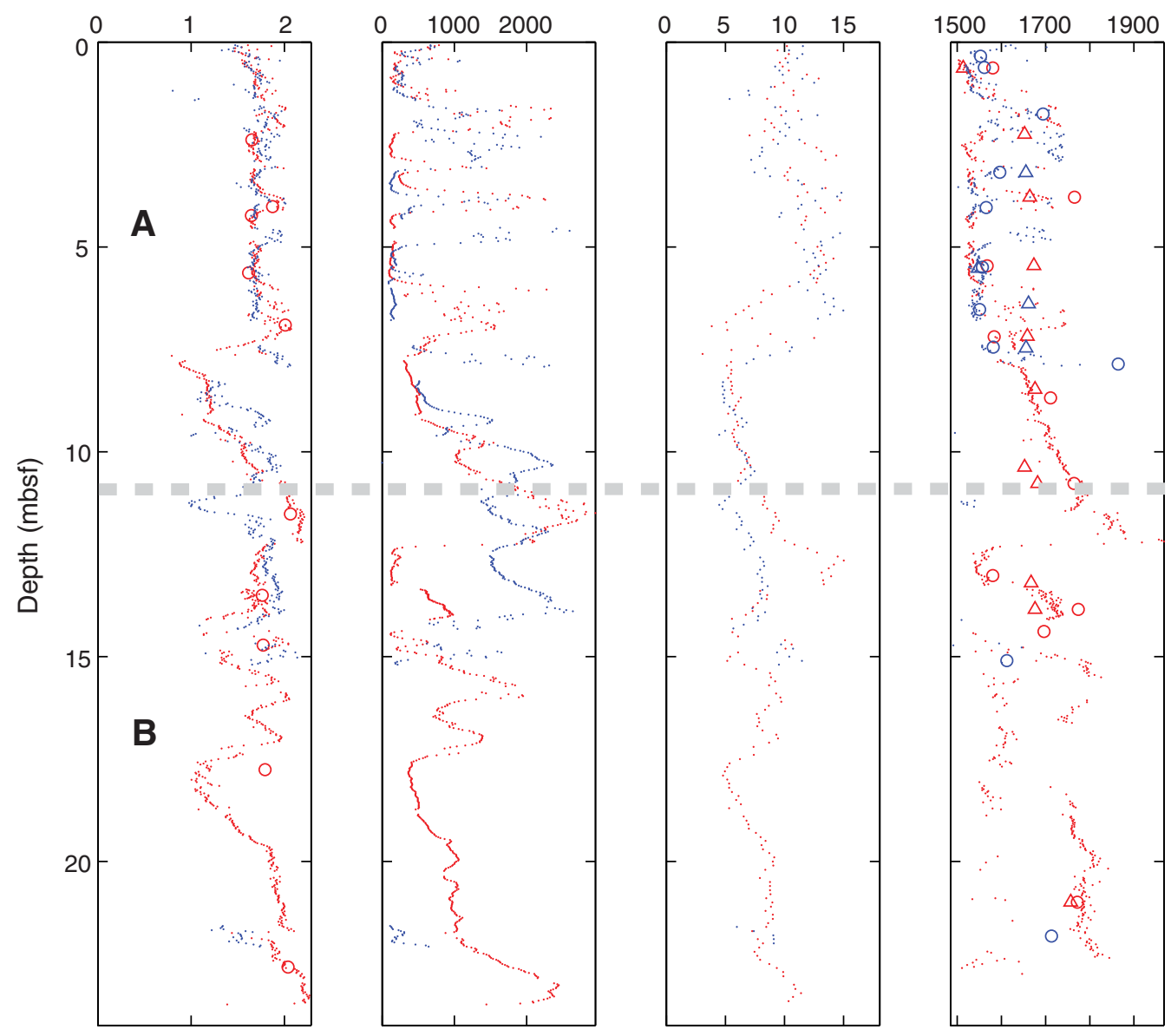

O P-wave $\mathrm{x}$

$\triangle P$-wave $\mathrm{z}$

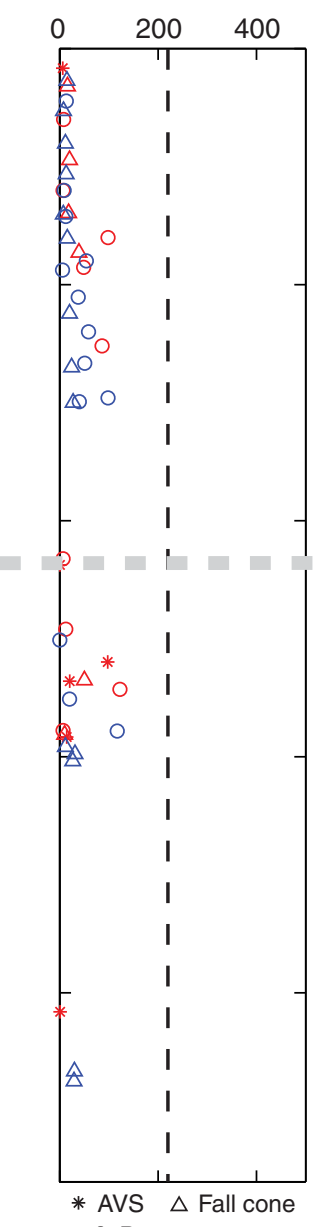

Porosity

(\%)

Thermal conductivity $(\mathrm{W} /[\mathrm{m} \cdot \mathrm{K}])$ 
Figure F8 (continued). B. 40-220 mbsf.

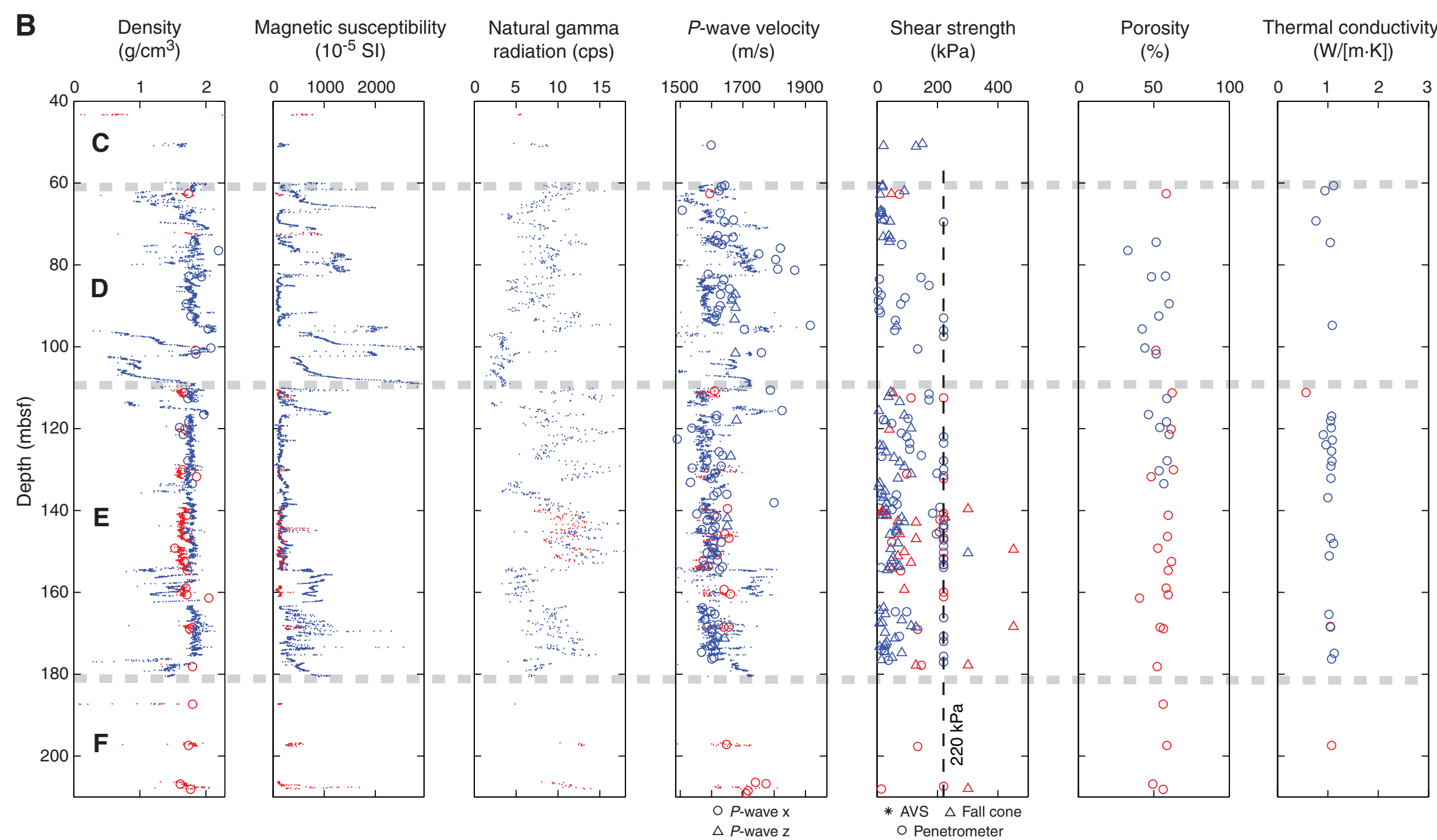


Figure F9. Plots of intensity of $\mathrm{NRM}_{0}$ (red) and $\mathrm{NRM}_{20}$ (blue) and inclination and declination after $20 \mathrm{mT}$ demagnetization, Hole U1394A. For inclination data, gray points are all measurements made and red data are data from hemipelagic sediment. For declination data, gray points are unoriented declinations and red points are FlexIt tool-corrected data from hemipelagic sediment. Black squares are discrete declination and inclination measurements shown against a geocentric axial dipole (GAD) inclination of $30.9^{\circ}$.

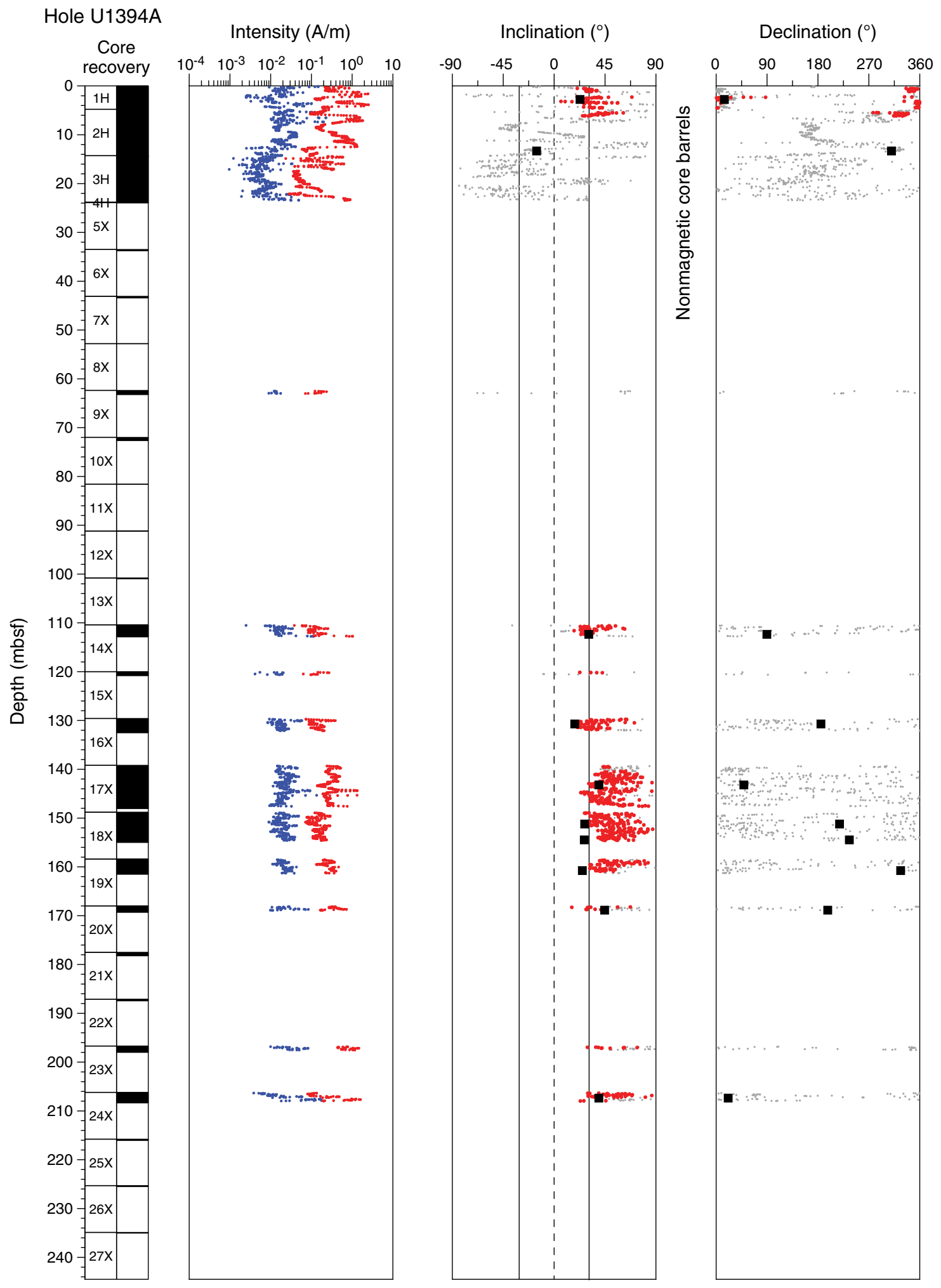


Figure F10. Plots of intensity of $\mathrm{NRM}_{0}$ (red) and $\mathrm{NRM}_{20}$ (blue) and inclination and declination after $20 \mathrm{mT}$ demagnetization, Hole U1394B. For inclination data, gray points are all measurements made and red data are data from hemipelagic sediment. For declination data, gray points are unoriented declinations and orange points are from hemipelagic sediment rotated and guided by discrete inclination data. Black squares are discrete declination and inclination measurements shown against a geocentric axial dipole (GAD) inclination of $30.9^{\circ}$.

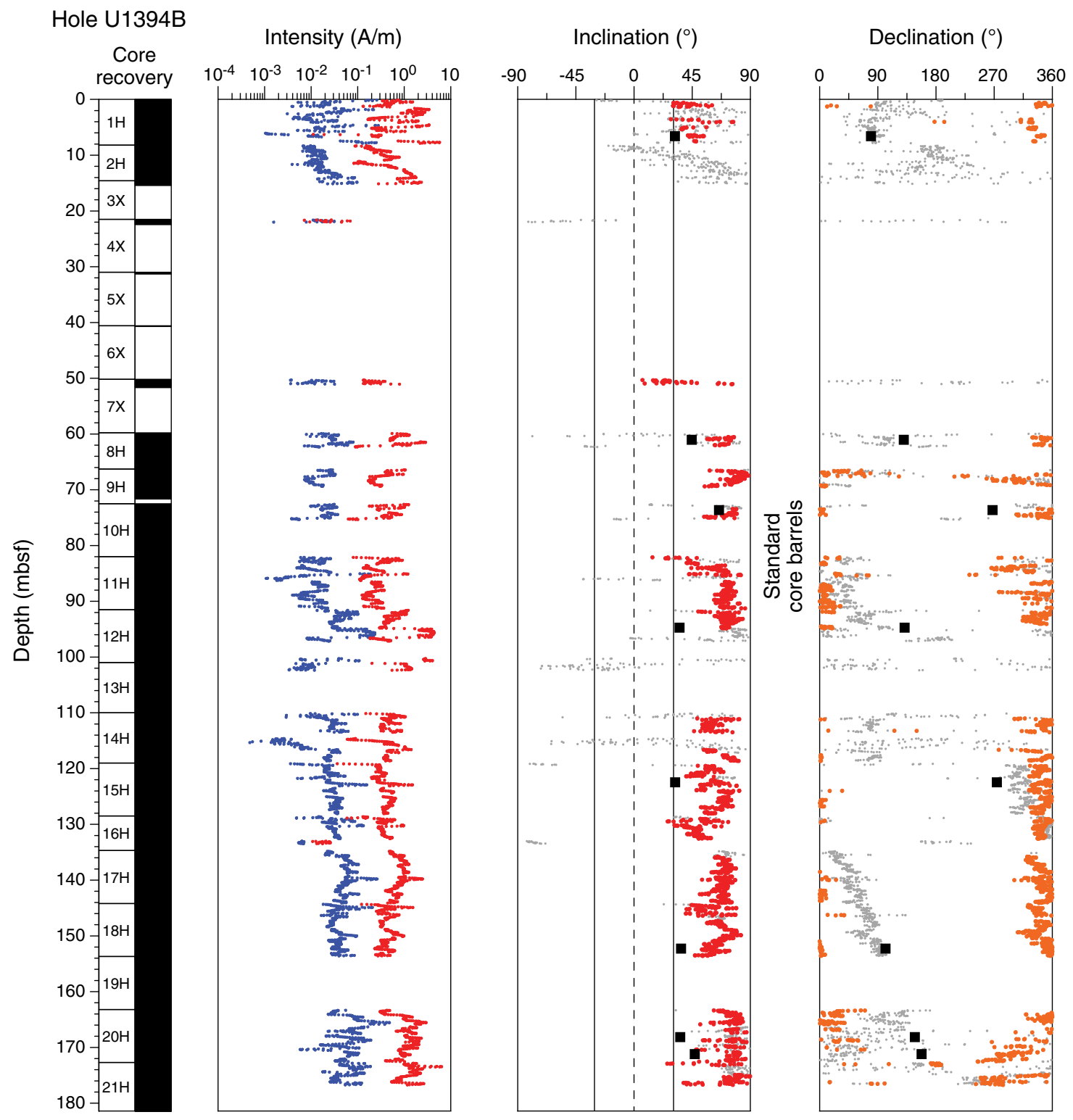


Figure F11. Zijderveld plots for three representative samples each from Holes U1394A and U1394B. Inset shows normalized demagnetization spectra for each sample to $60 \mathrm{mT}$. AF $=$ alternating field.

\section{Hole U1394A}

A $\quad 340-\mathrm{U} 1394 \mathrm{~A}-1 \mathrm{H}-2 \mathrm{~W}, 128 \mathrm{~cm}(2.78 \mathrm{mbsf})$

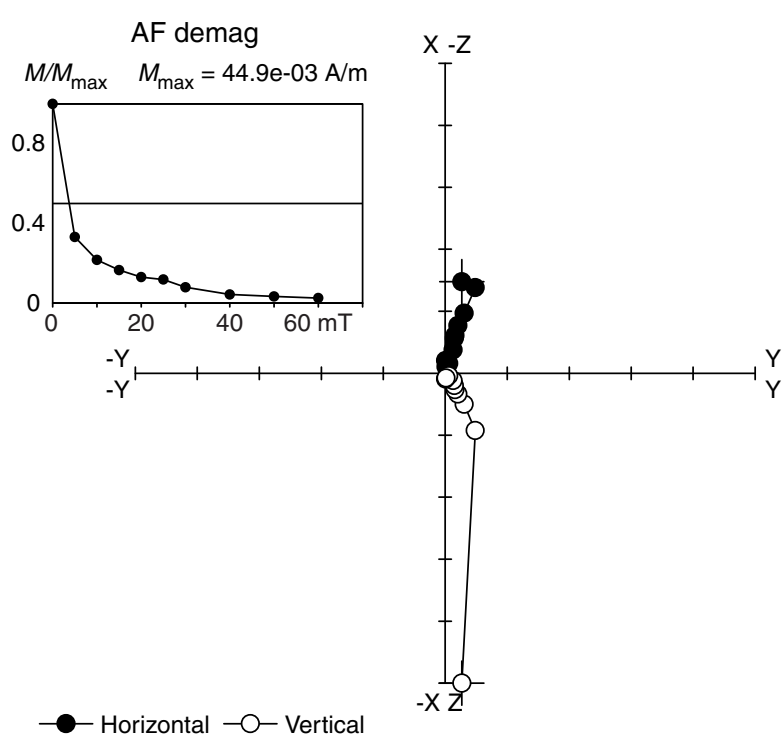

B

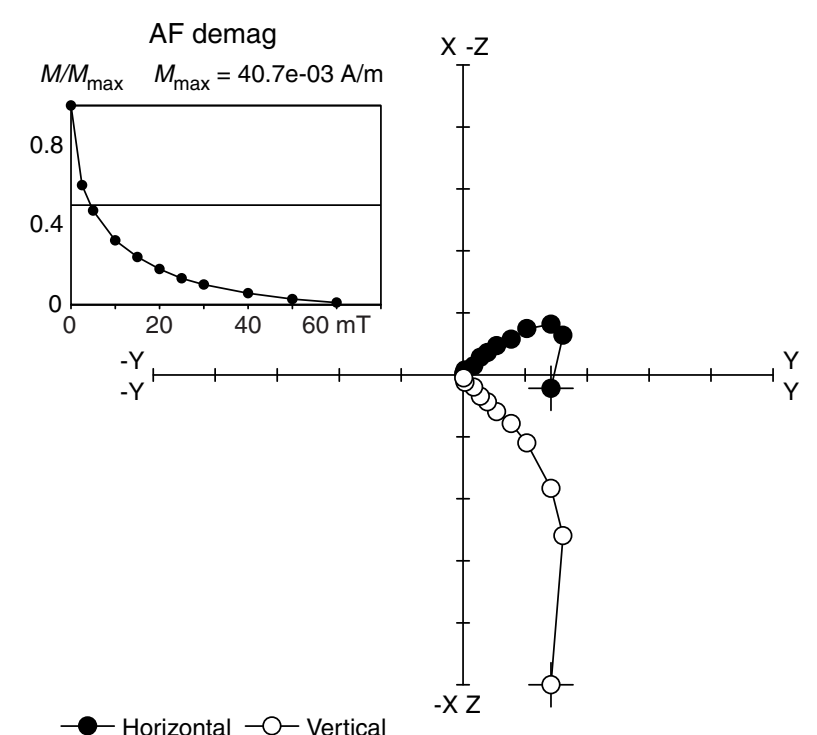

C 340-U1394A-2H-6W, $103 \mathrm{~cm}(13.33 \mathrm{mbsf})$

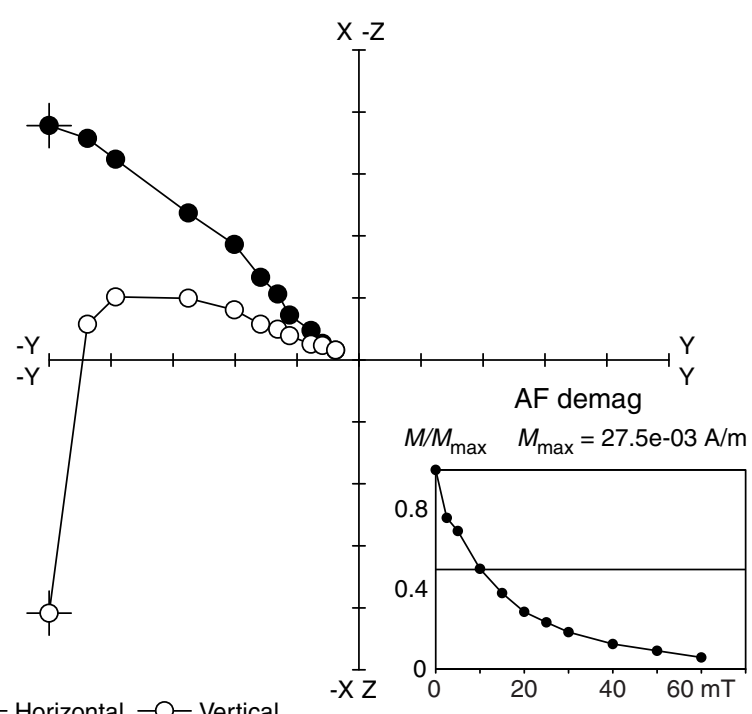

\section{Hole U1394B}

D 340-U1394B-8H-1W, $126 \mathrm{~cm}(61.04 \mathrm{mbsf})$

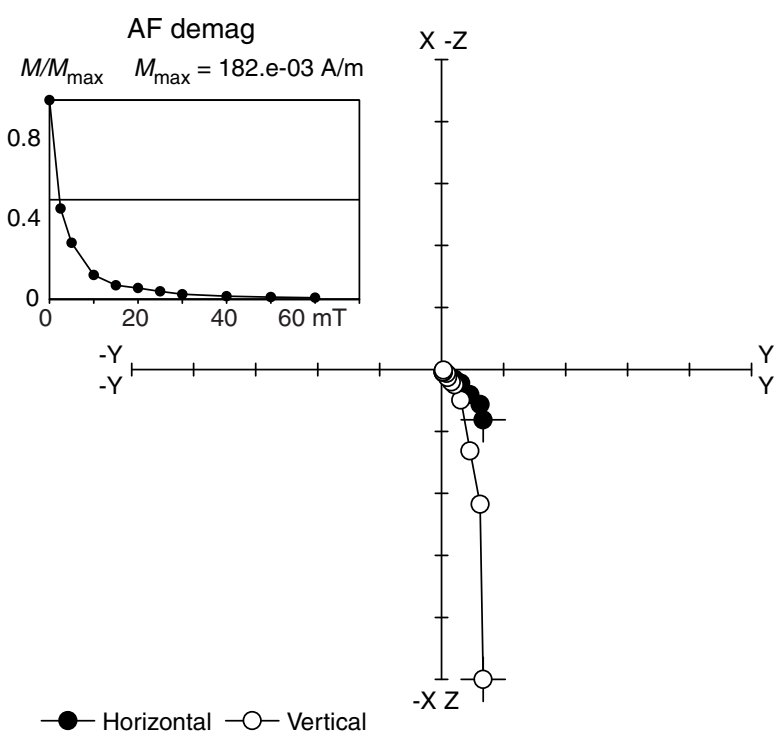

E $\quad 340-U 1394 \mathrm{~B}-15 \mathrm{H}-3 \mathrm{~W}, 52 \mathrm{~cm}(122.46 \mathrm{mbsf})$
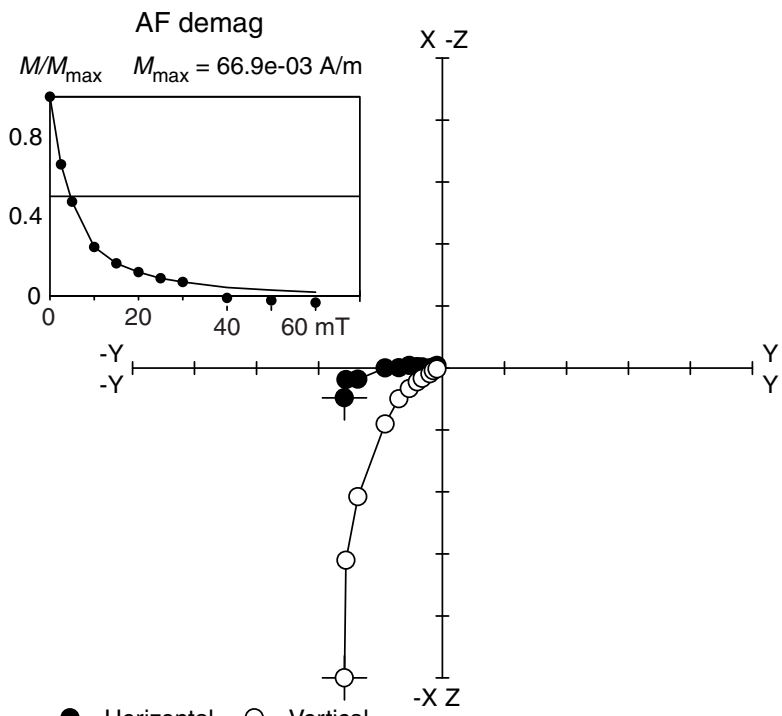

Horizontal $-\mathrm{O}-$ Vertical

F $\quad 340-U 1394 B-20 \mathrm{H}-6 \mathrm{~W}, 52 \mathrm{~cm}$ (171.18 mbsf)

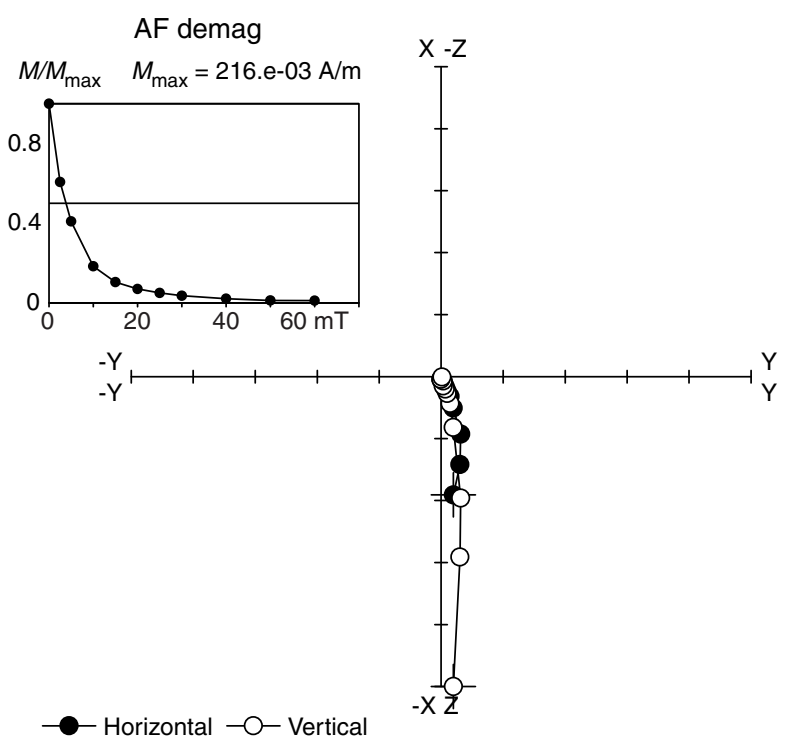


Figure F12. Schematic of tool string deployments in Hole U1394B. MSS = Magnetic Susceptibility Sonde, VSI = Versatile Seismic Imager, FMS = Formation MicroScanner.

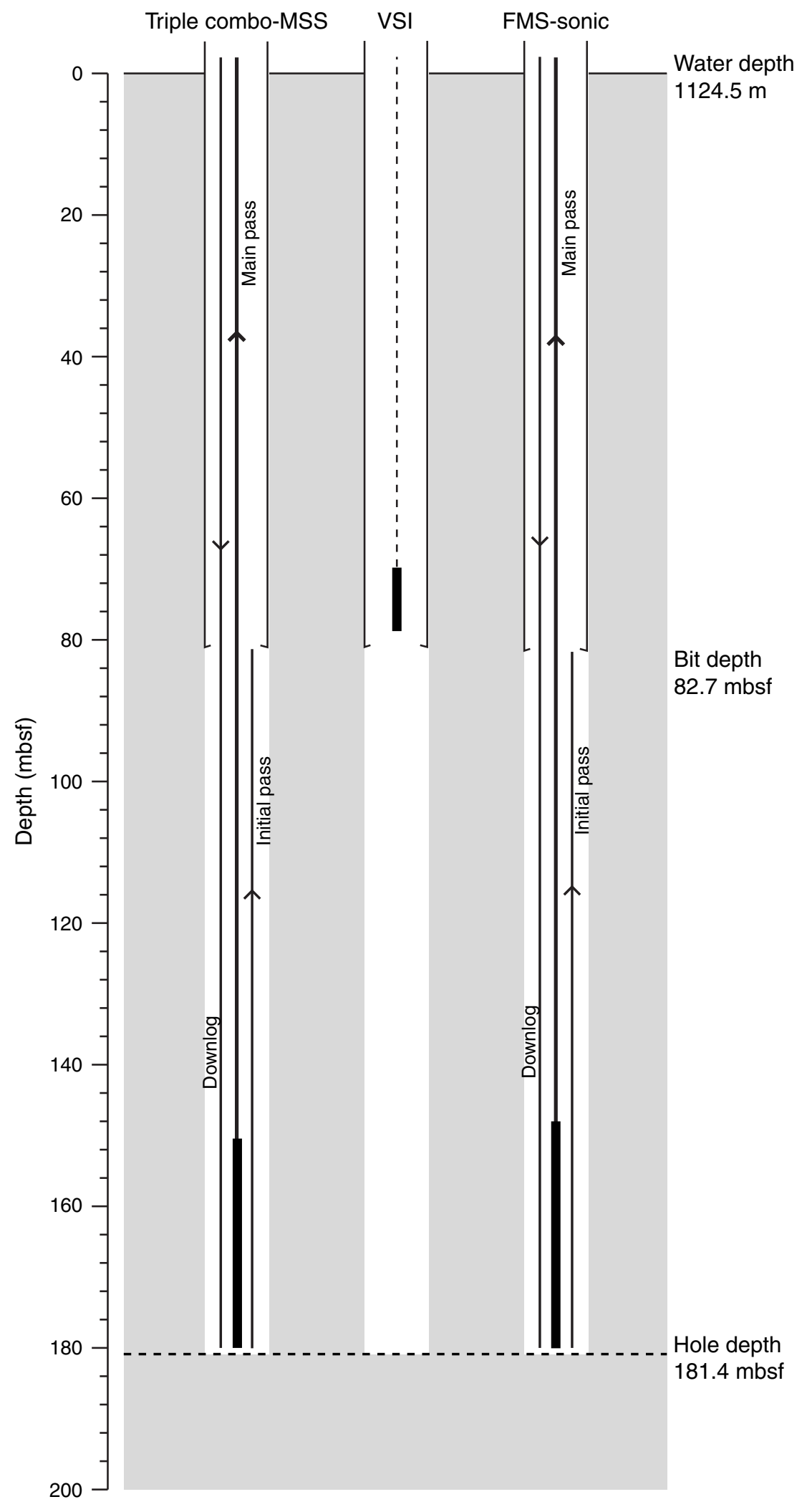


Figure F13. Summary of logs recorded by the triple combo tool string and comparison to physical properties measured on recovered cores, Hole U1394B. NGR = natural gamma radiation. High-Resolution Laterolog Array (HRLA) readings: $\mathrm{R} 3$ = medium resistivity, R5 = deepest resistivity, RT = true resistivity, modeled from all depths of investigation. uncal $=$ uncalibrated units.

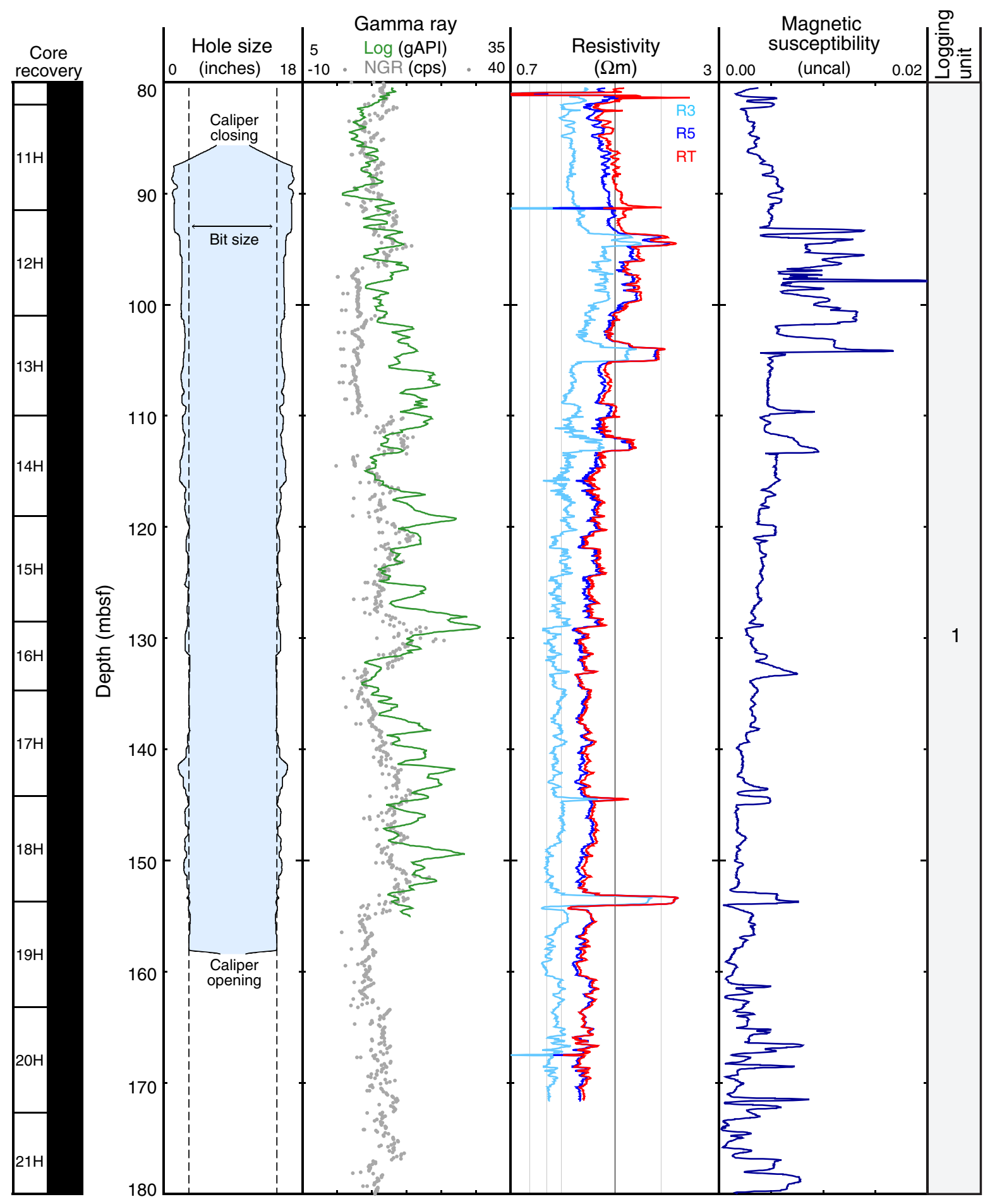


Figure F14. Summary of logs recorded by the Formation MicroScanner (FMS)-sonic tool string, Hole U1394B. Hole size is measured by the two orthogonal calipers of the FMS (C1 and C2). Gamma ray recorded during the FMS-sonic run (FMS) is compared to gamma ray recorded by the triple combo run (TC). The high waveform coherence, in red in the velocity tracks, is a measure of the reliability of the slowness/time coherence algorithm used to derive compressional $\left(V_{\mathrm{P}}\right)$ and shear $\left(V_{S}\right)$ wave velocities from the monopole and lower dipole sonic waveforms, respectively.

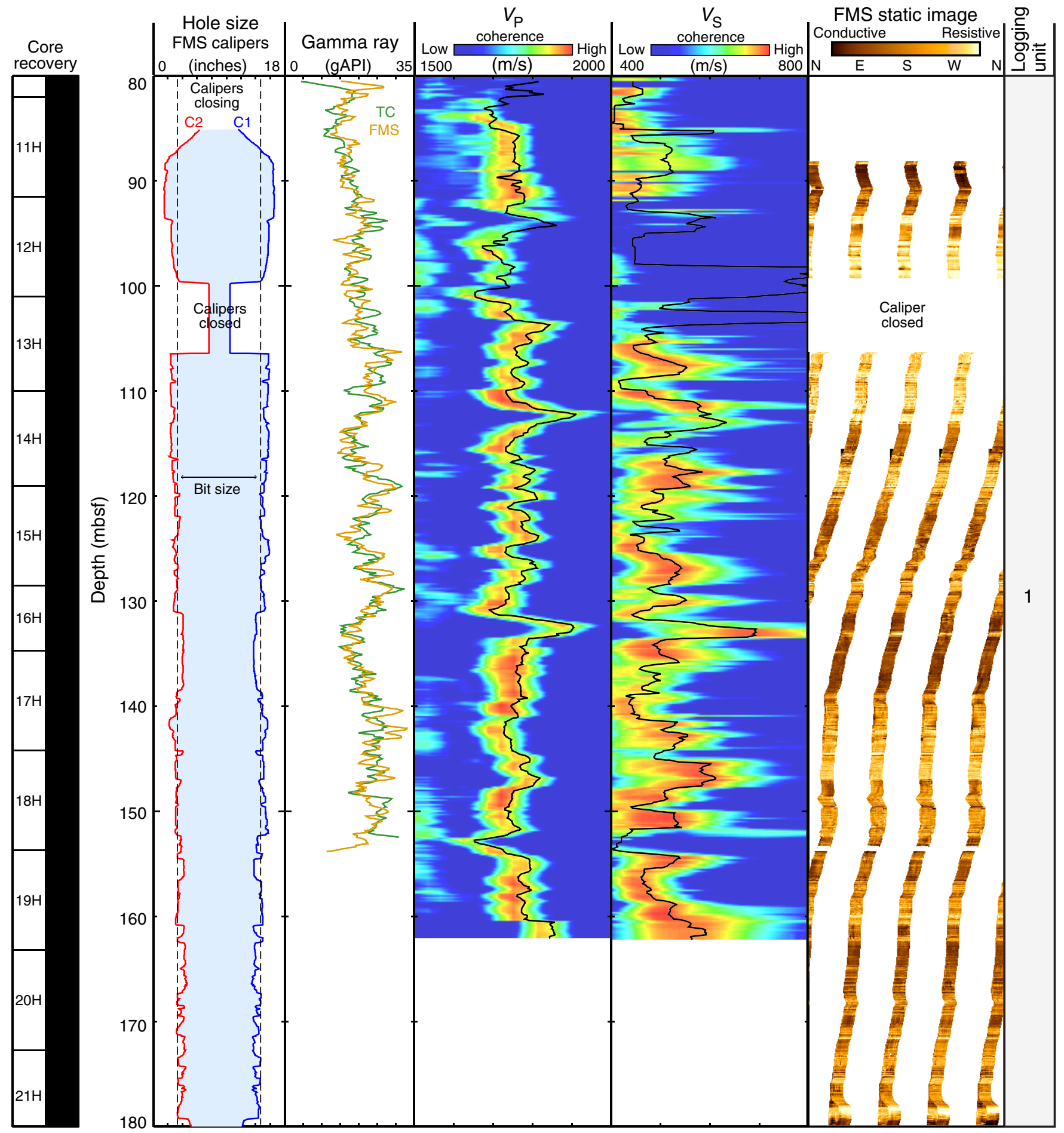


Figure F15. Summary of spectral natural gamma radiation measurements, Hole U1394B. SGR = total gamma ray, CGR = computed gamma ray or gamma ray without the contribution of uranium. The area between the two curves shows the contribution of uranium, a common indicator of organic content.

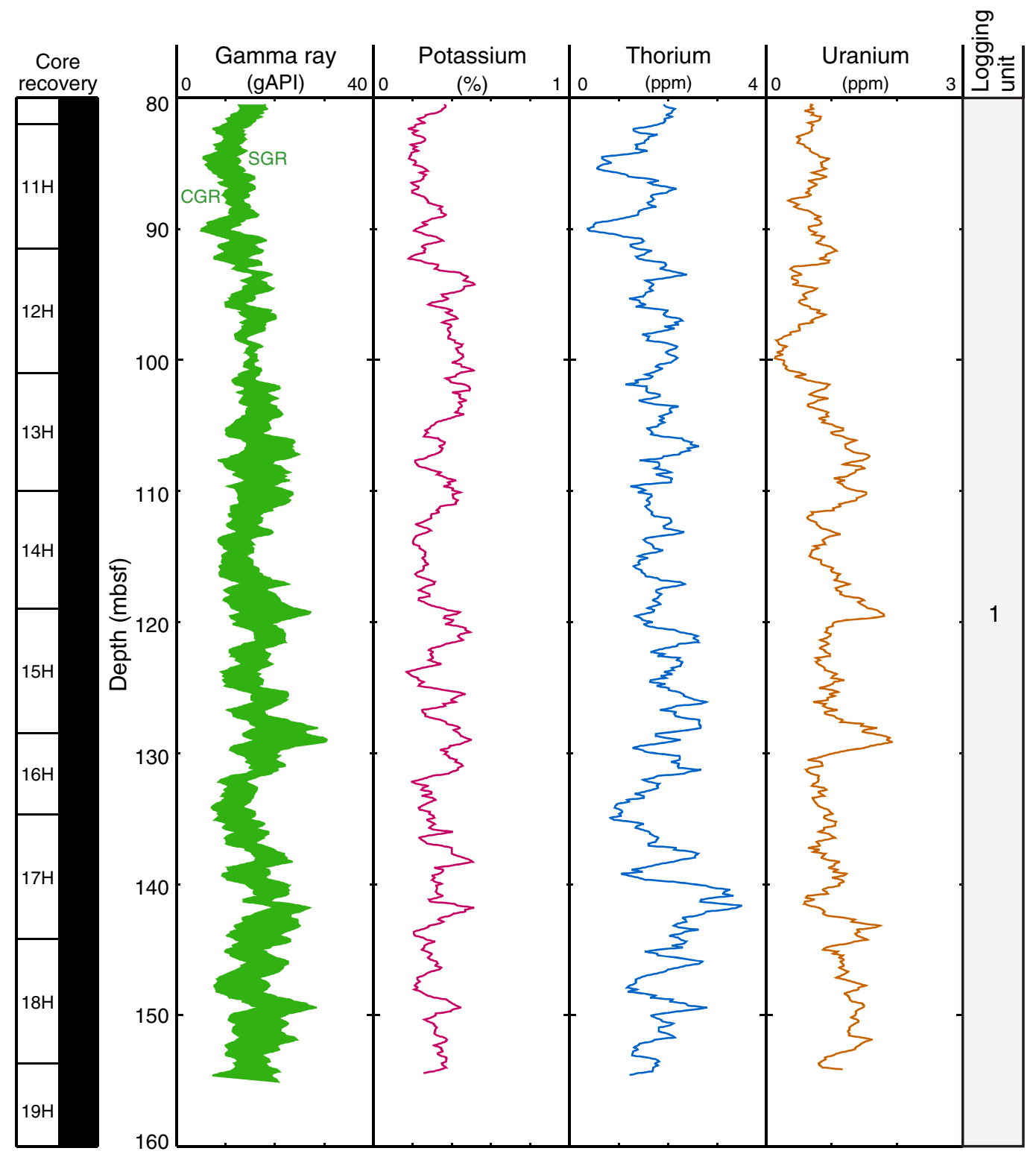


Figure F16. Comparison of some of the main logs recorded during consecutive logging passes, Hole U1394B. All data sets show good agreement between the two passes, indicating the reliability of the various measurements. uncal $=$ uncalibrated units.

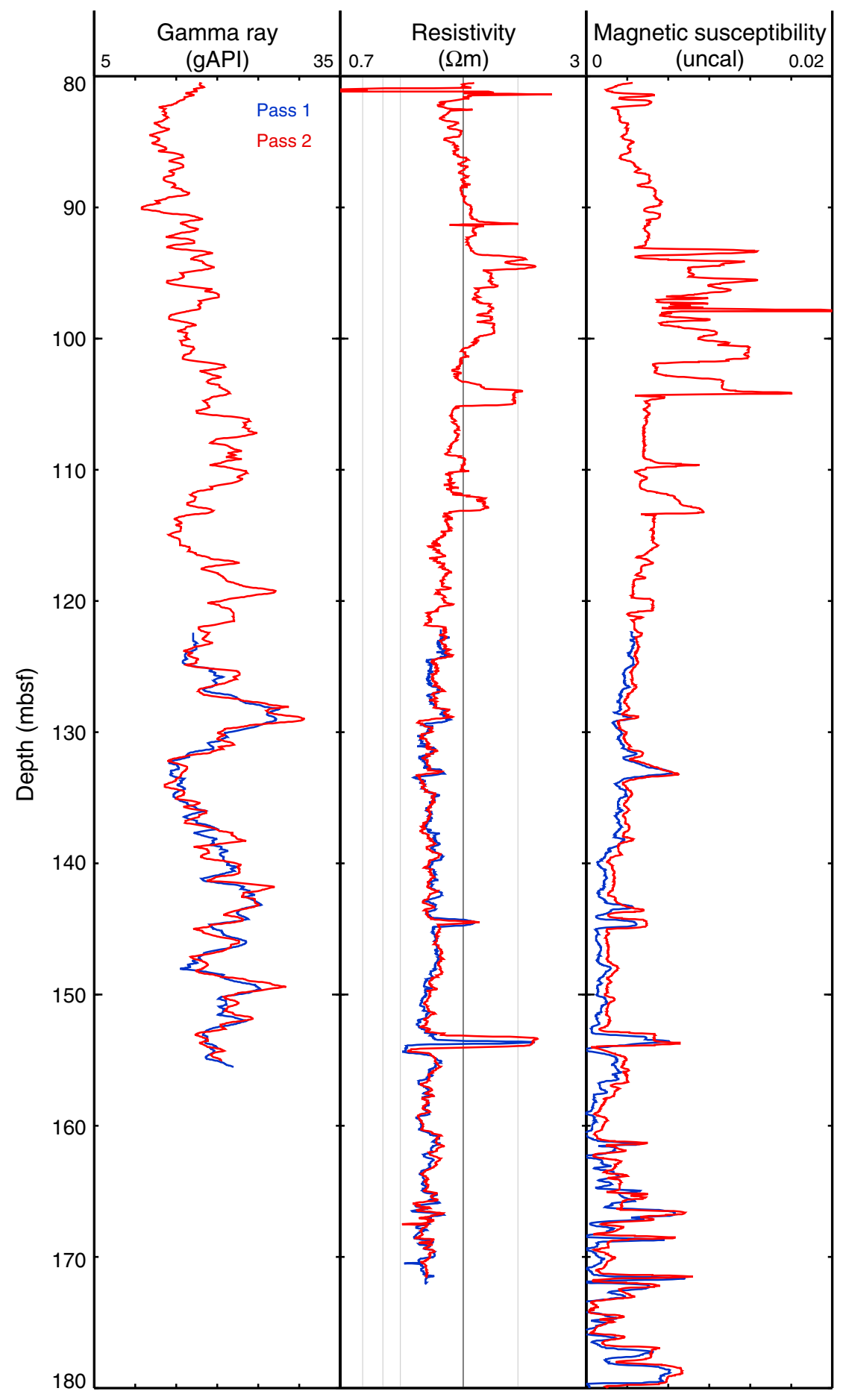


Figure F17. Comparison of magnetic susceptibility recorded with the wireline Magnetic Susceptibility Sonde (MSS) with susceptibility measured on the multisensor loggers, Hole U1394B. Similar features are recorded by the two measurements; however, a clear depth offset between the two data sets increases with distance downhole. Gray bands indicate features that may be correlated between the two data sets, characterized by high electrical resistivity (in logging data) and high magnetic susceptibility (in logging and core data). Examples from core photographs show that some of these features correspond to a debris deposit (Cores 340-U1394B-12H and $13 \mathrm{H})$, volcaniclastic sand, and volcaniclastic turbidites (Core $18 \mathrm{H})$. Core $18 \mathrm{H}$ is also shown in a comparison with FMS images for the interval 143.65 through 145.15 mbsf in Figure F18A. uncal = uncalibrated units.

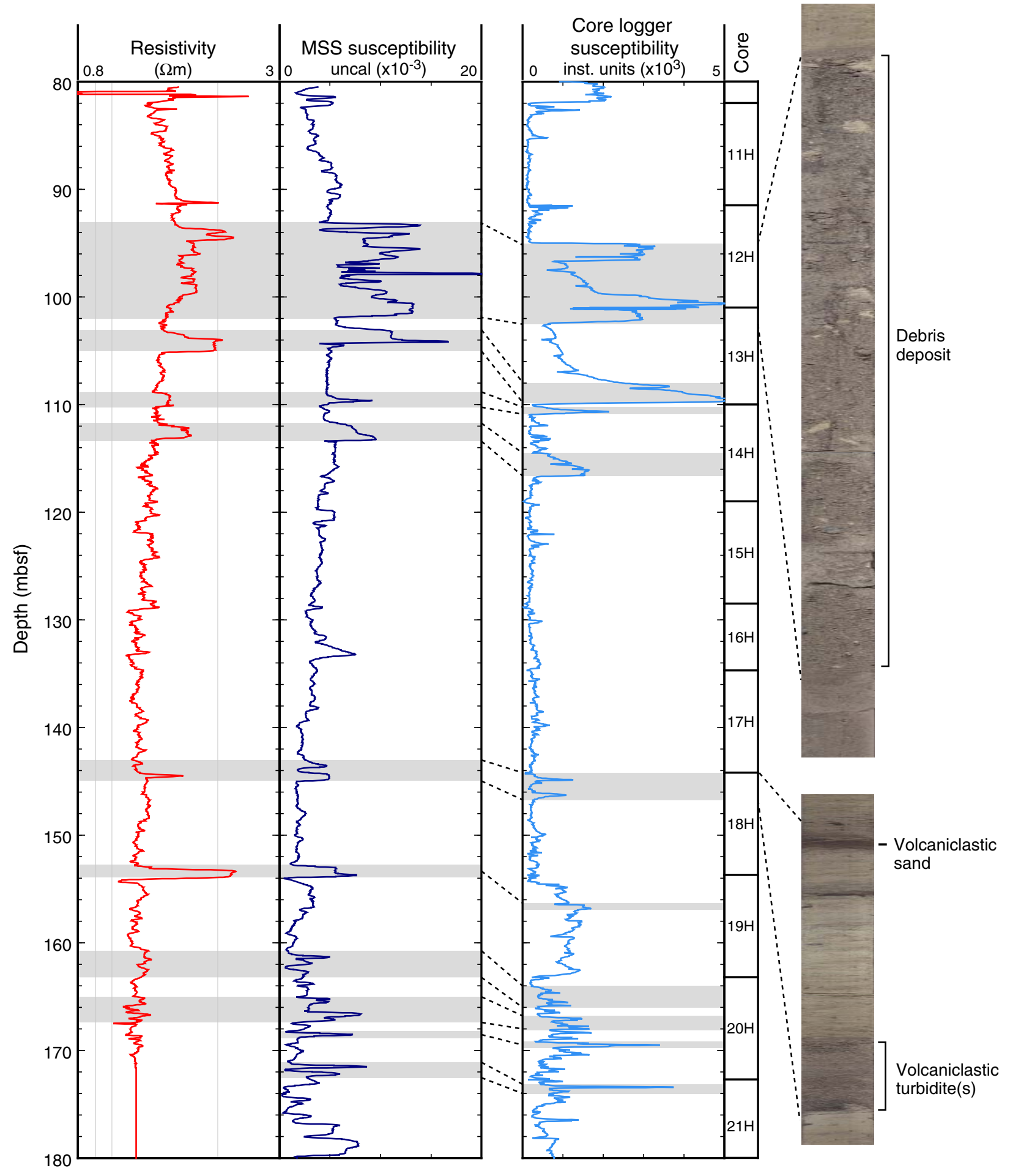


Figure F18. Examples of statically processed FMS images, representative of some of the lithologies recovered in Hole U1394B (see Fig. F17 for relation to other data). A. Static FMS image from 143.65 to 145.15 mbsf. Conductive subhorizontal layers in FMS images seem to correspond with darker intervals in Section 340U1394B-18H-1. B. Static FMS image from 112.15 to 113.55 mbsf. Lithological change observed in Section 340U1394B-14H-5 corresponds with a change in resistivity across a dipping boundary.

A
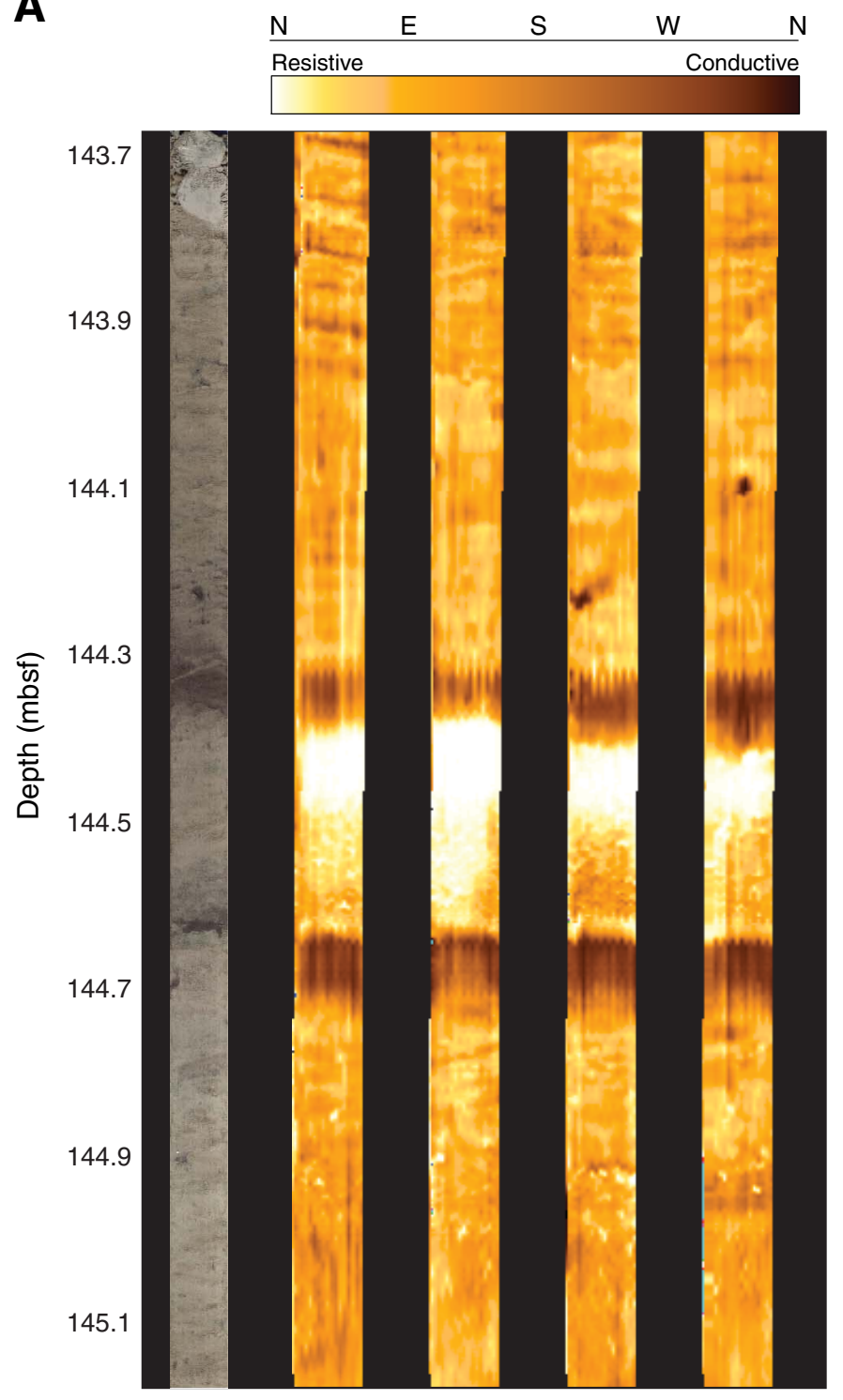

B

\begin{tabular}{lllll}
$\mathrm{N}$ & $\mathrm{E}$ & $\mathrm{S}$ & $\mathrm{W}$ & $\mathrm{N}$ \\
\hline Resistive & & & & Conductive
\end{tabular}

112.2

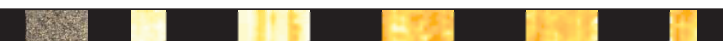

112.4

112.6

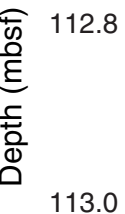

113.0

113.2
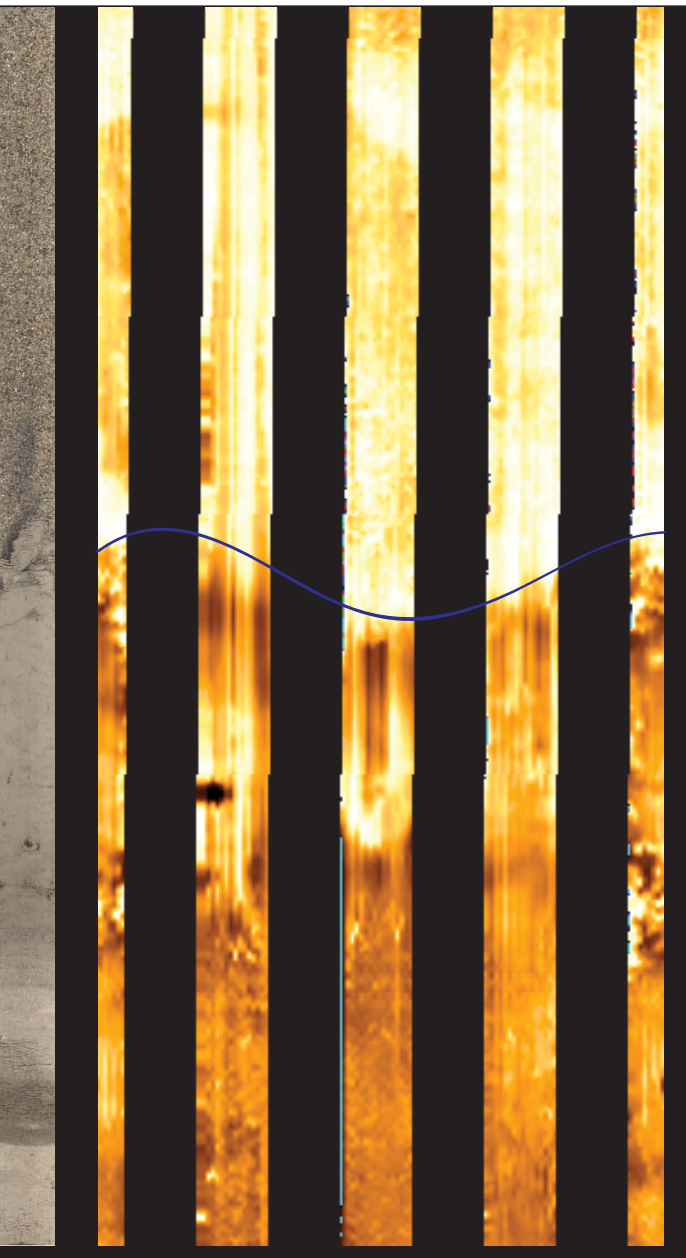
Table T1. Coring summary, Site U1394. (Continued on next page.)

\begin{tabular}{|c|c|c|c|c|c|c|c|c|c|c|}
\hline \multicolumn{3}{|l|}{ Hole: } & \multicolumn{8}{|c|}{ U1394A } \\
\hline \multicolumn{3}{|c|}{ Latitude: } & \multicolumn{8}{|c|}{$16^{\circ} 38.4259^{\prime} \mathrm{N}$} \\
\hline \multicolumn{3}{|c|}{ Longitude: } & \multicolumn{8}{|c|}{$062^{\circ} 02.2822^{\prime} \mathrm{W}$} \\
\hline \multicolumn{3}{|c|}{ Water depth $(\mathrm{m})$ : } & \multicolumn{8}{|c|}{1114.9} \\
\hline \multicolumn{3}{|c|}{ Date started (UTC*): } & \multicolumn{8}{|c|}{0830 h 8 March 2012} \\
\hline Date $f$ & inished (UTC & & $1445 \mathrm{~h}$ & 10 March & 2012 & & & & & \\
\hline Time & on hole (days & & 2.13 & & & & & & & \\
\hline Seaflo & or depth DR & $F(m):$ & 1126.3 & & & & & & & \\
\hline Penetr & ation DSF ( $\mathrm{n}$ & & 244.5 & & & & & & & \\
\hline Cored & interval $(\mathrm{m})$ & & 244.5 & & & & & & & \\
\hline Recov & ered length & (m): & 57.37 & & & & & & & \\
\hline Recov & ery (\%): & & 23 & & & & & & & \\
\hline Total c & ores (no.): & & 27 & & & & & & & \\
\hline Hole: & & & U1394 & & & & & & & \\
\hline Latitu & & & $16^{\circ} 38$ & $4375^{\prime} \mathrm{N}$ & & & & & & \\
\hline Longit & ude: & & $062^{\circ} 02$ & $.2819^{\prime} \mathrm{W}$ & & & & & & \\
\hline Water & depth $(m)$ : & & 1114.2 & & & & & & & \\
\hline Date s & tarted (UTC' & & $1445 \mathrm{~h}$ & 10 March & 2012 & & & & & \\
\hline Date $f$ & inished (UTC & & $2145 \mathrm{~h}$ & 12 March & 2012 & & & & & \\
\hline Time & on hole (days & & 2.13 & & & & & & & \\
\hline Seaflo & or depth DR & $F(m):$ & 1125.6 & & & & & & & \\
\hline Penetr & ation DSF (n & & 181.4 & & & & & & & \\
\hline Cored & interval $(\mathrm{m})$ & & 181.4 & & & & & & & \\
\hline Recov & ered length & (m): & 141.15 & & & & & & & \\
\hline Recov & ery (\%): & & 78 & & & & & & & \\
\hline Total c & ores (no.): & & 21 & & & & & & & \\
\hline Core & $\begin{array}{l}\text { Top depth } \\
\text { drilled } \\
\text { DSF (m) }\end{array}$ & $\begin{array}{r}\text { Botto } \\
d r \\
\text { DS }\end{array}$ & $\begin{array}{l}n \text { depth } \\
\text { illed } \\
F(m)\end{array}$ & $\begin{array}{l}\text { Advanced } \\
\text { (m) }\end{array}$ & $\begin{array}{l}\text { Recovered } \\
\text { length } \\
\text { (m) }\end{array}$ & $\begin{array}{l}\text { Curated } \\
\text { length } \\
(\mathrm{m})\end{array}$ & $\begin{array}{l}\text { Top depth } \\
\text { cored } \\
\text { CSF (m) }\end{array}$ & $\begin{array}{l}\text { Bottom depth } \\
\text { recovered } \\
\text { CSF }(\mathrm{m})\end{array}$ & $\begin{array}{l}\text { Recovery } \\
(\%)\end{array}$ & $\begin{array}{c}\text { Time on deck } \\
\text { (UTC*) }\end{array}$ \\
\hline $340-\mathrm{U1}$ & 394A- & & & & & & & & & \\
\hline $1 \mathrm{H}$ & 0.0 & & 4.8 & 4.8 & 4.85 & 4.85 & 0.0 & 4.85 & 101 & $3 / 9 / 122350$ \\
\hline $2 \mathrm{H}$ & 4.8 & & 4.3 & 9.5 & 9.80 & 9.80 & 4.8 & 14.60 & 103 & $3 / 9 / 120110$ \\
\hline $3 \mathrm{H}$ & 14.3 & & 3.8 & 9.5 & 9.42 & 9.42 & 14.3 & 23.72 & 99 & 3/9/12 0215 \\
\hline $4 \mathrm{H}$ & 23.8 & & 3.9 & 0.1 & 0.10 & 0.10 & 23.8 & 23.90 & 100 & $3 / 9 / 120330$ \\
\hline $5 X$ & 23.9 & & 3.5 & 9.6 & 0.02 & 0.05 & 23.9 & 23.95 & 0 & $3 / 9 / 120525$ \\
\hline $6 \mathrm{X}$ & 33.5 & & 3.1 & 9.6 & 0.18 & 0.27 & 33.5 & 33.77 & 2 & 3/9/12 0632 \\
\hline $7 X$ & 43.1 & & 2.8 & 9.7 & 0.40 & 0.33 & 43.1 & 43.43 & 4 & $3 / 9 / 120800$ \\
\hline $8 X$ & 52.8 & & 2.4 & 9.6 & 0.00 & 0.00 & 52.8 & 52.80 & 0 & $3 / 9 / 120900$ \\
\hline $9 \mathrm{X}$ & 62.4 & & 2.0 & 9.6 & 0.91 & 0.84 & 62.4 & 63.24 & 9 & $3 / 9 / 120950$ \\
\hline $10 x$ & 72.0 & & 1.6 & 9.6 & 0.67 & 0.67 & 72.0 & 72.67 & 7 & 3/9/12 1115 \\
\hline $11 \mathrm{X}$ & 81.6 & & 1.2 & 9.6 & 0.03 & 0.03 & 81.6 & 81.63 & 0 & 3/9/12 1200 \\
\hline $12 x$ & 91.2 & 10 & & 9.6 & 0.00 & 0.00 & 91.2 & 91.20 & 0 & 3/9/12 1300 \\
\hline $13 x$ & 100.8 & 11 & 0.4 & 9.6 & 0.18 & 0.18 & 100.8 & 100.98 & 2 & 3/9/12 1355 \\
\hline $14 X$ & 110.4 & 12 & 0.0 & 9.6 & 2.48 & 2.48 & 110.4 & 112.88 & 26 & $3 / 9 / 121455$ \\
\hline $15 X$ & 120.0 & 12 & & 9.6 & 0.83 & 0.83 & 120.0 & 120.83 & 9 & 3/9/12 1540 \\
\hline $16 \mathrm{X}$ & 129.6 & 13 & 9.2 & 9.6 & 2.92 & 2.92 & 129.6 & 132.52 & 30 & 3/9/12 1640 \\
\hline $17 X$ & 139.2 & 14 & & 9.6 & 8.86 & 8.86 & 139.2 & 148.06 & 92 & $3 / 10 / 121725$ \\
\hline $18 \mathrm{X}$ & 148.8 & 15 & 8.4 & 9.6 & 6.20 & 6.20 & 148.8 & 155.00 & 65 & $3 / 10 / 121815$ \\
\hline $19 \mathrm{X}$ & 158.4 & 16 & 8.0 & 9.6 & 3.11 & 3.11 & 158.4 & 161.51 & 32 & 3/10/12 1905 \\
\hline $20 x$ & 168.0 & 17 & & 9.5 & 1.32 & 1.32 & 168.0 & 169.32 & 14 & $3 / 10 / 122015$ \\
\hline $21 x$ & 177.5 & 18 & 7.1 & 9.6 & 0.73 & 0.73 & 177.5 & 178.23 & 8 & $3 / 10 / 122100$ \\
\hline $22 x$ & 187.1 & 19 & 6.7 & 9.6 & 0.36 & 0.36 & 187.1 & 187.46 & 4 & $3 / 10 / 122155$ \\
\hline $23 X$ & 196.7 & 20 & 6.2 & 9.5 & 1.31 & 1.31 & 196.7 & 198.01 & 14 & 3/10/12 2315 \\
\hline $24 X$ & 206.2 & 21 & 5.8 & 9.6 & 2.16 & 2.16 & 206.2 & 208.36 & 23 & $3 / 10 / 120015$ \\
\hline $25 x$ & 215.8 & 22 & 5.3 & 9.5 & 0.21 & 0.25 & 215.8 & 216.05 & 2 & $3 / 10 / 120115$ \\
\hline $26 X$ & 225.3 & 23 & 4.9 & 9.6 & 0.20 & 0.20 & 225.3 & 225.50 & 2 & $3 / 10 / 120200$ \\
\hline $27 X$ & 234.9 & 24 & 4.5 & 9.6 & 0.12 & 0.12 & 234.9 & 235.02 & 1 & $3 / 10 / 120310$ \\
\hline $340-U 1$ & 394B- & & & & & & & & & \\
\hline $1 \mathrm{H}$ & 0.0 & & 8.2 & 8.2 & 8.26 & 8.26 & 0.0 & 8.26 & 101 & $3 / 11 / 120705$ \\
\hline $2 \mathrm{H}$ & 8.2 & & 4.6 & 6.4 & 6.47 & 6.47 & 8.2 & 14.67 & 101 & $3 / 11 / 120810$ \\
\hline $3 x$ & 14.6 & & 1.5 & 6.9 & 0.84 & 0.84 & 14.6 & 15.44 & 12 & $3 / 11 / 120940$ \\
\hline $4 X$ & 21.5 & & 1.0 & 9.5 & 0.95 & 0.95 & 21.5 & 22.45 & 10 & $3 / 11 / 121105$ \\
\hline $5 X$ & 31.0 & & 0.6 & 9.6 & 0.33 & 0.33 & 31.0 & 31.33 & 3 & $3 / 11 / 121240$ \\
\hline $6 X$ & 40.6 & & 0.2 & 9.6 & 0.13 & 0.13 & 40.6 & 40.73 & 1 & $3 / 11 / 121430$ \\
\hline $7 X$ & 50.2 & & 9.8 & 9.6 & 1.48 & 1.48 & 50.2 & 51.68 & 15 & $3 / 11 / 121510$ \\
\hline $8 \mathrm{H}$ & 59.8 & & 6.3 & 6.5 & 6.53 & 6.53 & 59.8 & 66.33 & 100 & $3 / 11 / 121540$ \\
\hline $9 \mathrm{H}$ & 66.3 & & 2.5 & 6.2 & 5.36 & 5.36 & 66.3 & 71.66 & 86 & $3 / 11 / 121640$ \\
\hline $10 \mathrm{H}$ & 72.5 & & 2.0 & 9.5 & 9.56 & 9.56 & 72.5 & 82.06 & 101 & $3 / 11 / 121750$ \\
\hline $11 \mathrm{H}$ & 82.0 & & 1.5 & 9.5 & 9.80 & 9.80 & 82.0 & 91.80 & 103 & $3 / 11 / 121925$ \\
\hline
\end{tabular}


Table T1 (continued).

\begin{tabular}{|c|c|c|c|c|c|c|c|c|c|}
\hline Core & $\begin{array}{l}\text { Top depth } \\
\text { drilled } \\
\text { DSF }(m)\end{array}$ & $\begin{array}{l}\text { Bottom depth } \\
\text { drilled } \\
\text { DSF }(m)\end{array}$ & $\begin{array}{l}\text { Advanced } \\
(\mathrm{m})\end{array}$ & $\begin{array}{l}\text { Recovered } \\
\text { length } \\
(\mathrm{m})\end{array}$ & $\begin{array}{l}\text { Curated } \\
\text { length } \\
\text { (m) }\end{array}$ & $\begin{array}{l}\text { Top depth } \\
\text { cored } \\
\text { CSF }(\mathrm{m})\end{array}$ & $\begin{array}{l}\text { Bottom depth } \\
\text { recovered } \\
\text { CSF }(m)\end{array}$ & $\begin{array}{l}\text { Recovery } \\
\text { (\%) }\end{array}$ & $\begin{array}{l}\text { Time on deck } \\
\left(\text { UTC }^{*}\right)\end{array}$ \\
\hline $12 \mathrm{H}$ & 91.5 & 101.0 & 9.5 & 9.88 & 9.88 & 91.5 & 101.38 & 104 & $3 / 11 / 121950$ \\
\hline $13 \mathrm{H}$ & 101.0 & 110.0 & 9.0 & 9.05 & 9.05 & 101.0 & 110.05 & 101 & $3 / 11 / 122035$ \\
\hline $14 \mathrm{H}$ & 110.0 & 119.0 & 9.0 & 9.03 & 9.03 & 110.0 & 119.03 & 100 & $3 / 11 / 122150$ \\
\hline $15 \mathrm{H}$ & 119.0 & 128.5 & 9.5 & 9.68 & 9.68 & 119.0 & 128.68 & 102 & $3 / 11 / 122320$ \\
\hline $16 \mathrm{H}$ & 128.5 & 134.7 & 6.2 & 6.22 & 6.22 & 128.5 & 134.72 & 100 & $3 / 12 / 120010$ \\
\hline $17 \mathrm{H}$ & 134.7 & 144.2 & 9.5 & 9.87 & 9.87 & 134.7 & 144.57 & 104 & $3 / 12 / 120210$ \\
\hline $18 \mathrm{H}$ & 144.2 & 153.7 & 9.5 & 9.98 & 9.98 & 144.2 & 154.18 & 105 & $3 / 12 / 120335$ \\
\hline $19 \mathrm{H}$ & 153.7 & 163.2 & 9.5 & 9.48 & 9.48 & 153.7 & 163.18 & 100 & $3 / 12 / 120425$ \\
\hline $20 \mathrm{H}$ & 163.2 & 172.7 & 9.5 & 9.55 & 9.55 & 163.2 & 172.75 & 101 & $3 / 12 / 120605$ \\
\hline \multirow[t]{2}{*}{$21 \mathrm{H}$} & 172.7 & 181.4 & 8.7 & 8.70 & 8.70 & 172.7 & 181.40 & 100 & $3 / 12 / 120705$ \\
\hline & & Totals: & 425.9 & 198.52 & 98.54 & & & & \\
\hline
\end{tabular}

* = ship local time was Universal Time Coordinated (UTC) - $4 \mathrm{~h} . \mathrm{DRF}=$ drilling depth below rig floor, DSF = drilling depth below seafloor, CSF = core depth below seafloor. $\mathrm{H}=$ advanced piston corer, $\mathrm{X}=$ extended core barrel. 
Table T2. Solid-phase geochemistry, Site U1394.

\begin{tabular}{|c|c|c|c|c|c|c|c|}
\hline \multirow{2}{*}{$\begin{array}{l}\text { Core, } \\
\text { section }\end{array}$} & \multicolumn{2}{|c|}{ Depth (mbsf) } & \multicolumn{4}{|c|}{ Carbon (wt\%) } & \multirow{2}{*}{$\begin{array}{l}\text { Nitroger } \\
\text { (wt\%) }\end{array}$} \\
\hline & Top & Bottom & $\mathrm{CaCO}_{3}$ & Inorganic & Total & Organic & \\
\hline \multicolumn{8}{|c|}{ 340-U1394A- } \\
\hline $1 \mathrm{H}-2$ & 2.44 & 2.45 & 74.09 & 8.88 & 9.80 & 0.92 & 0.02 \\
\hline $1 \mathrm{H}-4$ & 4.24 & 4.25 & 67.54 & 8.10 & 9.04 & 0.94 & 0.02 \\
\hline $2 \mathrm{H}-1$ & 5.61 & 5.62 & 59.18 & 7.10 & 7.93 & 0.84 & 0.04 \\
\hline $2 \mathrm{H}-5$ & 11.67 & 11.68 & 3.66 & 0.44 & 0.46 & 0.02 & $\mathrm{BD}$ \\
\hline $2 \mathrm{H}-7$ & 13.79 & 13.80 & 7.54 & 0.90 & 1.06 & 0.16 & $\mathrm{BD}$ \\
\hline $3 \mathrm{H}-1$ & 14.67 & 14.68 & 65.97 & 7.91 & 8.84 & 0.93 & 0.02 \\
\hline $3 \mathrm{H}-3$ & 17.73 & 17.74 & 33.80 & 4.05 & 4.45 & 0.40 & BD \\
\hline $3 \mathrm{H}-6$ & 22.53 & 22.54 & 34.55 & 4.14 & 4.57 & 0.43 & $\mathrm{BD}$ \\
\hline $9 X-1$ & 62.57 & 62.58 & 60.93 & 7.31 & 8.14 & 0.83 & 0.02 \\
\hline $9 X-1$ & 62.57 & 62.58 & & & 8.15 & & 0.02 \\
\hline $9 X-1$ & 62.57 & 62.58 & & & 8.16 & & 0.02 \\
\hline $14 X-1$ & 111.20 & 111.21 & 62.15 & 7.45 & 8.26 & 0.81 & 0.02 \\
\hline $16 \mathrm{X}-1$ & 130.08 & 130.09 & 12.60 & 1.51 & 1.85 & 0.34 & 0.02 \\
\hline $16 X-2$ & 131.69 & 131.70 & 57.31 & 6.87 & 7.83 & 0.96 & 0.03 \\
\hline $17 X-2$ & 141.17 & 141.18 & 57.46 & 6.89 & 7.89 & 1.00 & 0.03 \\
\hline $17 X-5$ & 146.42 & 146.43 & 58.96 & 7.07 & 8.07 & 1.00 & 0.04 \\
\hline $18 X-1$ & 149.24 & 149.25 & 36.65 & 4.39 & 4.90 & 0.51 & 0.02 \\
\hline $18 X-3$ & 152.51 & 152.52 & 55.42 & 6.65 & 7.57 & 0.92 & 0.03 \\
\hline $18 X-4$ & 154.60 & 154.61 & 53.68 & 6.44 & 7.33 & 0.89 & 0.03 \\
\hline $19 X-1$ & 158.92 & 158.93 & 61.08 & 7.32 & 8.19 & 0.87 & 0.01 \\
\hline $19 X-2$ & 160.57 & 160.58 & 54.99 & 6.59 & 7.65 & 1.06 & 0.03 \\
\hline $19 \mathrm{X}-\mathrm{CC}$ & 161.43 & 161.44 & 66.52 & 7.98 & 9.07 & .09 & 0.01 \\
\hline $20 X-1$ & 168.57 & 168.58 & 32.15 & 3.86 & 4.37 & 0.52 & 0.02 \\
\hline $20 X-1$ & 168.90 & 168.91 & 53.74 & 6.44 & 7.63 & 1.19 & 0.02 \\
\hline $21 X-C C$ & 178.14 & 178.15 & 35.83 & 4.30 & 4.88 & 0.58 & 0.01 \\
\hline $22 X-1$ & 187.31 & 187.32 & 54.74 & 6.56 & 7.39 & 0.83 & 0.01 \\
\hline $23 X-1$ & 197.38 & 197.39 & 46.26 & 5.55 & 6.85 & 1.30 & 0.02 \\
\hline $24 X-1$ & 206.81 & 206.82 & 60.11 & 7.21 & 8.04 & 0.83 & 0.02 \\
\hline $24 X-C C$ & 208.17 & 208.18 & 43.67 & 5.24 & 6.05 & 0.81 & 0.03 \\
\hline \multicolumn{8}{|c|}{ 340-U1394B- } \\
\hline $10 \mathrm{H}-2$ & 74.455 & 74.465 & 32.41 & 3.89 & 4.35 & 0.46 & 0.02 \\
\hline $10 \mathrm{H}-2$ & 74.455 & 74.465 & 31.78 & 3.81 & & & \\
\hline $10 \mathrm{H}-3$ & 76.56 & 76.57 & 64.56 & 7.74 & 7.83 & 0.09 & 0.01 \\
\hline $11 \mathrm{H}-1$ & 82.70 & 82.71 & & & 8.07 & & 0.03 \\
\hline $11 \mathrm{H}-1$ & 82.70 & 82.71 & & & 8.08 & & 0.03 \\
\hline $11 \mathrm{H}-1$ & 82.915 & 82.925 & 60.77 & 7.29 & 7.62 & 0.33 & 0.01 \\
\hline $11 \mathrm{H}-6$ & 89.69 & 89.70 & 76.79 & 9.21 & 9.89 & 0.68 & 0.02 \\
\hline $12 \mathrm{H}-1$ & 92.47 & 92.48 & 53.76 & 6.45 & 7.61 & 1.16 & 0.03 \\
\hline $12 \mathrm{H}-3$ & 95.79 & 95.80 & 21.27 & 2.55 & 2.67 & 0.12 & BD \\
\hline $12 \mathrm{H}-7$ & 100.56 & 100.57 & 1.46 & 0.17 & 0.48 & 0.31 & $\mathrm{BD}$ \\
\hline $13 \mathrm{H}-1$ & 101.70 & 101.71 & 1.45 & 0.17 & 0.4 & 0.23 & $\mathrm{BD}$ \\
\hline $14 \mathrm{H}-2$ & 112.60 & 112.61 & 58.38 & 7.00 & 7.64 & 0.64 & 0.04 \\
\hline $14 \mathrm{H}-5$ & 116.50 & 116.51 & 38.28 & 4.59 & 5.20 & 0.61 & 0.01 \\
\hline $14 \mathrm{H}-6$ & 118.29 & 118.30 & 70.87 & 8.50 & 9.16 & 0.66 & 0.03 \\
\hline $15 \mathrm{H}-1$ & 119.71 & 119.72 & 61.74 & 7.40 & 8.37 & 0.97 & 0.03 \\
\hline $15 \mathrm{H}-2$ & 121.45 & 121.46 & 51.57 & 6.18 & 6.97 & 0.79 & 0.01 \\
\hline $15 \mathrm{H}-7$ & 127.94 & 127.95 & 62.49 & 7.49 & 8.23 & 0.74 & 0.02 \\
\hline $16 \mathrm{H}-2$ & 130.21 & 130.22 & 13.38 & 1.60 & 2.70 & 1.10 & 0.02 \\
\hline $16 \mathrm{H}-4$ & 133.40 & 133.41 & 69.14 & 8.29 & 8.82 & 0.53 & 0.01 \\
\hline $20 \mathrm{H}-7$ & 171.97 & 171.98 & 0.42 & 0.05 & 0.18 & 0.13 & 0.01 \\
\hline
\end{tabular}

$\mathrm{BD}=$ below detection, values reported as 0. Blank cells = not analyzed. 
Table T3. Composition of interstitial pore water, Hole U1394B.

\begin{tabular}{|c|c|c|c|c|c|c|c|c|c|c|c|c|c|c|c|c|c|c|}
\hline \multirow{2}{*}{$\begin{array}{l}\text { Core, } \\
\text { section }\end{array}$} & \multicolumn{2}{|c|}{ Depth (mbsf) } & \multirow{2}{*}{$\begin{array}{l}\text { Alkalinity } \\
(\mathrm{mM})\end{array}$} & \multirow[b]{2}{*}{$\mathrm{pH}$} & \multirow{2}{*}{$\begin{array}{c}\mathrm{Cl} \\
(\mathrm{mM})\end{array}$} & \multirow[b]{2}{*}{ \pm} & \multirow[b]{2}{*}{ Salinity } & \multirow{2}{*}{$\begin{array}{c}\mathrm{NH}_{4} \\
(\mathrm{mM})\end{array}$} & \multirow{2}{*}{$\begin{array}{c}\mathrm{Na} \\
(\mathrm{mM})\end{array}$} & \multirow[b]{2}{*}{ \pm} & \multirow{2}{*}{$\underset{(\mathrm{mM})}{\mathrm{Mg}}$} & \multirow[b]{2}{*}{ \pm} & \multirow{2}{*}{$\begin{array}{c}\mathrm{K} \\
(\mathrm{mM})\end{array}$} & \multirow[b]{2}{*}{ \pm} & \multirow{2}{*}{$\begin{array}{c}\mathrm{Ca} \\
(\mathrm{mM})\end{array}$} & \multirow[b]{2}{*}{ \pm} & \multirow{2}{*}{$\underset{(\mathrm{mM})}{\Sigma S}$} & \multirow[b]{2}{*}{ \pm} \\
\hline & Top & Bottom & & & & & & & & & & & & & & & & \\
\hline \multicolumn{19}{|c|}{ 340-U1394B- } \\
\hline $1 \mathrm{H}-3$ & 4.40 & 4.45 & 3.3 & 7.5 & 563.6 & 0.3 & 37 & 0.10 & 473.3 & 3.6 & 52.8 & 0.6 & 11.2 & 0.1 & 9.4 & 0.1 & 26.5 & 0.2 \\
\hline $1 \mathrm{H}-5$ & 7.30 & 7.35 & 3.4 & 8.2 & 556.7 & 9.9 & 36 & 0.16 & 484.3 & 11.0 & 53.4 & 0.8 & 11.1 & 0.1 & 8.6 & 0.1 & 25.9 & 0.1 \\
\hline $10 \mathrm{H}-1$ & 73.90 & 73.95 & 9.5 & 7.5 & 572.7 & 4.6 & 36 & 1.53 & 497.9 & 13.2 & 47.2 & 0.9 & 9.7 & 0.3 & 5.5 & 0.1 & 15.8 & 0.2 \\
\hline $11 \mathrm{H}-4$ & 87.92 & 88.02 & 10.3 & 7.5 & 570.8 & 6.0 & 36 & 1.74 & 486.9 & 2.2 & 47.4 & 0.3 & 8.9 & 0.1 & 6.2 & 0.1 & 16.4 & 0.2 \\
\hline $11 \mathrm{H}-6$ & 90.92 & 91.02 & 10.2 & 7.5 & 571.6 & & 37 & 1.73 & 492.1 & 4.1 & 48.2 & 0.3 & 9.0 & 0.2 & 6.4 & 0.1 & 16.6 & 0.3 \\
\hline $12 \mathrm{H}-2$ & 94.40 & 94.50 & 9.8 & 7.5 & 577.8 & & 37 & 1.78 & 498.9 & 17.6 & 48.2 & 1.2 & 9.3 & 0.3 & 6.1 & 0.1 & 16.9 & 0.5 \\
\hline $14 \mathrm{H}-5$ & 117.40 & 117.50 & 11.4 & 7.5 & 566.4 & 1.3 & 35 & 1.93 & 496.1 & 7.5 & 42.0 & 0.1 & 9.2 & 0.2 & 5.6 & 0.0 & 11.2 & 0.1 \\
\hline $15 \mathrm{H}-3$ & 123.40 & 123.50 & 10.4 & 7.4 & 576.6 & & 34 & 2.01 & 501.4 & 13.2 & 41.0 & 0.8 & 9.2 & 0.2 & 5.1 & 0.1 & 10.1 & 0.4 \\
\hline $15 \mathrm{H}-6$ & 127.72 & 127.82 & 11.4 & 7.5 & 574.1 & & 35 & 2.09 & 497.0 & 1.1 & 40.1 & 0.2 & 9.4 & 0.0 & 5.4 & 0.1 & 9.9 & 0.1 \\
\hline $16 \mathrm{H}-3$ & 132.80 & 132.90 & 11.5 & 7.5 & 581.6 & & 35 & 2.08 & 496.7 & 3.4 & 40.0 & 0.3 & 9.3 & 0.3 & 5.6 & 0.1 & 10.0 & 0.2 \\
\hline $17 \mathrm{H}-3$ & 139.00 & 139.10 & 11.5 & 7.5 & 581.5 & & 36 & 2.07 & 498.2 & 4.2 & 40.2 & 0.4 & 9.1 & 0.1 & 5.7 & 0.1 & 10.2 & 0.2 \\
\hline $17 \mathrm{H}-6$ & 143.46 & 143.56 & 9.7 & 7.5 & 580.3 & 1.3 & 35 & 2.02 & 502.2 & 2.6 & 40.1 & 0.3 & 9.2 & 0.1 & 5.4 & 0.1 & 10.6 & 0.2 \\
\hline $18 \mathrm{H}-3$ & 148.60 & 148.70 & 9.3 & 7.7 & 579.7 & 5.0 & 36 & 1.96 & 504.2 & 11.6 & 40.3 & 0.4 & 9.1 & 0.2 & 5.6 & 0.1 & 11.5 & 0.3 \\
\hline $18 \mathrm{H}-6$ & 151.72 & 151.82 & 8.6 & 7.5 & 578.3 & 0.6 & 36 & 2.01 & 500.1 & 4.1 & 40.1 & 0.4 & 9.1 & 0.1 & 5.7 & 0.1 & 12.1 & 0.2 \\
\hline $20 \mathrm{H}-2$ & 166.10 & 166.20 & 9.1 & 7.6 & 582.4 & 3.2 & 36 & 1.75 & 507.9 & 4.4 & 41.0 & 0.5 & 8.9 & 0.2 & 7.2 & 0.1 & 14.7 & 0.2 \\
\hline $20 \mathrm{H}-6$ & 171.87 & 171.97 & 8.4 & 7.8 & 571.7 & 16.8 & 36 & 1.80 & 501.2 & 2.7 & 40.4 & 0.3 & 8.9 & 0.3 & 7.0 & 0.1 & 15.3 & 0.2 \\
\hline $21 \mathrm{H}-3$ & 176.93 & 177.03 & 7.6 & 8.2 & 581.6 & 7.4 & 37 & 1.67 & 517.6 & 14.9 & 40.8 & 0.6 & 9.0 & 0.2 & 7.9 & 0.2 & 17.1 & 0.1 \\
\hline
\end{tabular}

Large $\mathrm{Cl}$ uncertainties for values from Sections 340-U1394B-1H-5 and $20 \mathrm{H}-6$ are a result of anomalously low values obtained during the first titration run. A subsequent run in triplicate for each sample yielded values for $1 \mathrm{H}-5=561.7 \pm 1.0 \mathrm{mM}$ and $20 \mathrm{H}-6=580.1 \pm 0.23 \mathrm{mM}$. Uncertainties for $\mathrm{Cl}$ represent $\pm 1 \sigma$ based on replicate analyses. Shaded samples represent average values for $\mathrm{Na}, \mathrm{Mg}, \mathrm{K}, \mathrm{Ca}$, and $\Sigma \mathrm{S}$ (total sulfur) from duplicate analyses from separate runs.

Table T4. Correlation point picks and depth shifts, Hole U1394A.

\begin{tabular}{rrr}
\hline $\begin{array}{c}\text { Original } \\
\text { depth } \\
\text { (mbsf) }\end{array}$ & $\begin{array}{c}\text { Corrected } \\
\text { depth } \\
\text { (mbsf) }\end{array}$ & \begin{tabular}{c}
\multicolumn{1}{c}{ Difference } \\
$(\mathrm{m})$
\end{tabular} \\
\hline 0.456 & 0.421 & 0.035 \\
1.659 & 1.191 & 0.469 \\
2.305 & 1.631 & 0.675 \\
2.405 & 1.735 & 0.670 \\
2.575 & 1.856 & 0.719 \\
2.804 & 2.058 & 0.746 \\
3.038 & 2.149 & 0.889 \\
3.133 & 2.217 & 0.916 \\
4.577 & 3.824 & 0.753 \\
7.688 & 6.041 & 1.648 \\
7.899 & 7.004 & 0.895 \\
9.194 & 9.772 & -0.578 \\
10.322 & 11.497 & -1.175 \\
11.947 & 13.983 & -2.036 \\
14.883 & 16.930 & -2.047 \\
111.941 & 111.181 & 0.760 \\
130.123 & 129.985 & 0.138 \\
144.867 & 144.346 & 0.521 \\
\hline
\end{tabular}


Table T5. Samples measured for paleomagnetism, Site U1394.

\begin{tabular}{|c|c|}
\hline Core & Measured \\
\hline \multicolumn{2}{|c|}{ 340-U1394A- } \\
\hline $1 \mathrm{H}$ & Yes \\
\hline $2 \mathrm{H}$ & Yes \\
\hline $3 \mathrm{H}$ & Yes \\
\hline $4 \mathrm{H}$ & Shorter than response function \\
\hline $5 x$ & Shorter than response function \\
\hline $6 x$ & Unsupported clasts \\
\hline $7 X$ & Unsupported clasts \\
\hline $8 X$ & Shorter than response function \\
\hline $9 x$ & Yes \\
\hline $10 \mathrm{x}$ & Massively disturbed \\
\hline $11 x$ & Unsupported clasts \\
\hline $12 x$ & Shorter than response function \\
\hline $13 x$ & Shorter than response function \\
\hline $14 X$ & Yes \\
\hline $15 x$ & Yes \\
\hline $16 x$ & Yes \\
\hline $17 X$ & Yes \\
\hline $18 x$ & Yes \\
\hline $19 x$ & Yes \\
\hline $20 x$ & Yes \\
\hline $21 x$ & Unsupported clasts \\
\hline $22 x$ & Unsupported clasts \\
\hline $23 x$ & Yes \\
\hline $24 X$ & Yes \\
\hline $25 X$ & Unsupported clasts \\
\hline $26 x$ & Unsupported clasts \\
\hline $27 X$ & Unsupported clasts \\
\hline \multicolumn{2}{|c|}{ 340-U1394B- } \\
\hline $1 \mathrm{H}$ & Yes \\
\hline $2 \mathrm{H}$ & Yes \\
\hline $3 x$ & Yes \\
\hline $4 X$ & Yes \\
\hline $5 X$ & Shorter than response function \\
\hline $6 \mathrm{X}$ & Shorter than response function \\
\hline $7 X$ & Yes \\
\hline $8 \mathrm{H}$ & Except for disturbed Sections 3A-5A \\
\hline $9 \mathrm{H}$ & Except for disturbed Sections 4A-5A \\
\hline $10 \mathrm{H}$ & Except for disturbed Sections 3A-7A \\
\hline $11 \mathrm{H}$ & Yes \\
\hline $12 \mathrm{H}$ & Except for disturbed Sections $5 \mathrm{~A}-6 \mathrm{~A}$ \\
\hline $13 \mathrm{H}$ & Except for disturbed Sections $12 \mathrm{~A}-6 \mathrm{~A}$ \\
\hline $14 \mathrm{H}$ & Yes \\
\hline $15 \mathrm{H}$ & Yes \\
\hline $16 \mathrm{H}$ & Except for disturbed Section $5 \mathrm{~A}$ \\
\hline $17 \mathrm{H}$ & Yes \\
\hline $18 \mathrm{H}$ & Yes \\
\hline $19 \mathrm{H}$ & Massively disturbed \\
\hline $20 \mathrm{H}$ & Yes \\
\hline $21 \mathrm{H}$ & Except for disturbed Sections 4A-7A \\
\hline
\end{tabular}

